
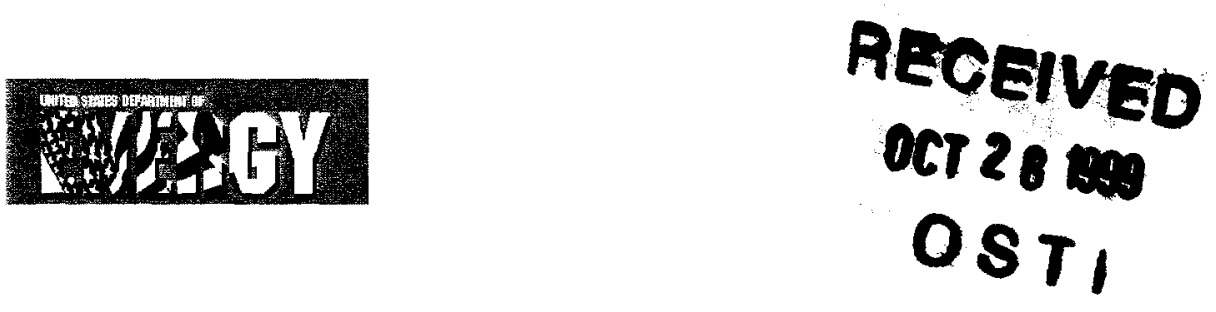

ORNL/CDIAC-120

NDP-072

\title{
A Database of Woody Vegetation Responses to Elevated Atmospheric $\mathrm{CO}_{2}$ Peter S. Curtis
}
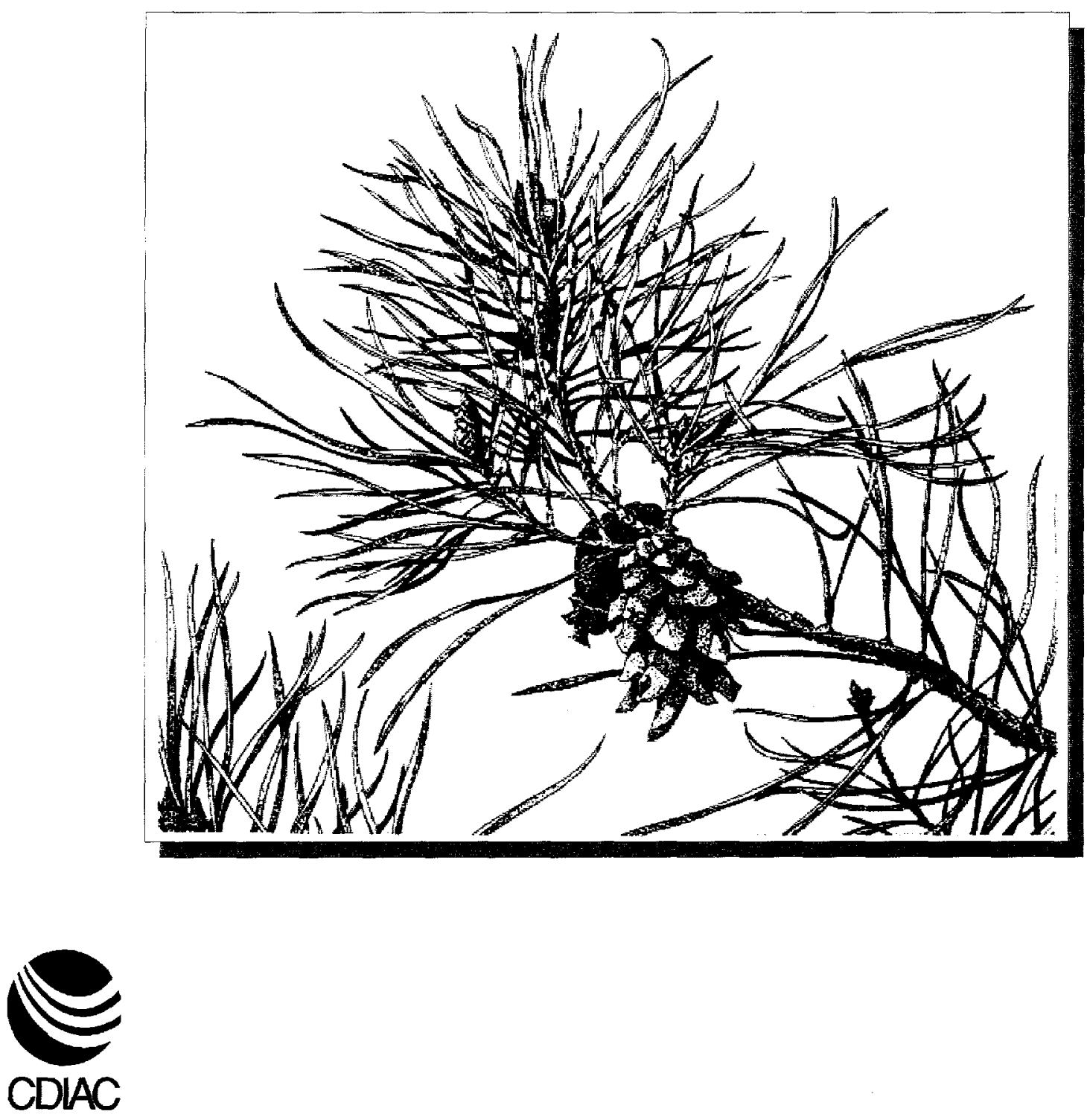
This report has been reproduced from the best available copy.

Reports are available to the public from the following source.

National Technical Information Service

5285 Port Royal Road

Springfield, VA 22161

Telephone 703-605-6000 (1-800-553-6847)

TDD 703-487-4639

Fax 703-605-6900

E-mail orders@ntis.fedworld.gov

Web site http://www.ntis.gov/ordering.htm

Reports are available to U.S. Department of Energy (DOE) employees, DOE contractors, Energy Technology Data Exchange (ETDE) representatives, and International Nuclear Information System (INIS) representatives from the following source.

Office of Scientific and Technical Information

P.O. Box 62

Oak Ridge, TN 37831

Telephone 423-576-8401

Fax 423-576-5728

E-mail reports@adonis.osti.gov

Web site http://www.osti.gov/products/sources.html

Reports produced after January 1, 1996, are generally available via the DOE Information Bridge. Web site http://www.doe.gov/bridge

\begin{abstract}
This report was prepared as an account of work sponsored by an agency of the United States government. Neither the United States government nor any agency thereof, nor any of their employees, makes any warranty, express or implied, or assumes any legal liability or responsibility for the accuracy, completeness, or usefulness of any information, apparatus, product, or process disclosed, or represents that its use would not infringe privately owned rights. Reference herein to any specific commercial product, process, or service by trade name, trademark, manufacturer, or otherwise, does not necessarily constitute or imply its endorsement, recommendation, or favoring by the United States government or any agency thereof. The views and opinions of authors expressed herein do not necessarily state or reflect those of the United States government or any agency thereof.
\end{abstract}

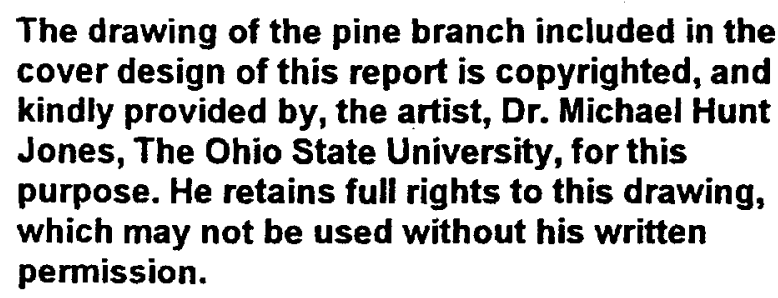




\section{DISCLAIMER}

Portions of this document may be illegible in electronic image products. Images are produced from the best available original document. 


\title{
A DATABASE OF WOODY VEGETATION RESPONSES TO ELEVATED ATMOSPHERIC $\mathrm{CO}_{2}$
}

\author{
Contributed by \\ Peter S. Curtis \\ Department of Evolution, Ecology, and Organismal Biology \\ The Ohio State University \\ Columbus, Ohio \\ Prepared by \\ Robert M. Cushman and Antoinette L. Brenkert* \\ Carbon Dioxide Information Analysis Center \\ * consultant, Washington, D.C. \\ Environmental Sciences Division \\ Publication No. 4888 \\ Date Published: September 1999 \\ Prepared for the \\ Environmental Sciences Division \\ Office of Biological and Environmental Research \\ U.S. Department of Energy \\ Budget Activity Number KP 1204010 \\ Prepared by the \\ Carbon Dioxide Information Analysis Center \\ Environmental Sciences Division \\ OAK RIDGE NATIONAL LABORATORY \\ Oak Ridge, Tennessee 37831-6335 \\ managed by \\ LOCKHEED MARTIN ENERGY RESEARCH CORP. \\ for the \\ U.S. DEPARTMENT OF ENERGY \\ under contract DE-AC05-96OR22464
}



CONTENTS

ABSTRACT

1. BACKGROUND INFORMATION

1

2. APPLICATIONS OF THE DATA $\ldots \ldots \ldots \ldots \ldots \ldots \ldots \ldots \ldots \ldots \ldots \ldots \ldots \ldots \ldots \ldots \ldots$

3. DATA LIMITATIONS AND RESTRICTIONS $\ldots \ldots \ldots \ldots \ldots \ldots \ldots \ldots \ldots \ldots \ldots$

4. DATA CHECKS AND PROCESSING PERFORMED BY CDIAC $\ldots \ldots \ldots \ldots \ldots \ldots \ldots 2$

5. INSTRUCTIONS FOR OBTAINING THE DATA AND DOCUMENTATION $\ldots \ldots \ldots \ldots 6$

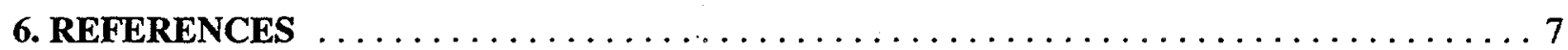

7. LISTING OF FILES PROVIDED $\ldots \ldots \ldots \ldots \ldots \ldots \ldots \ldots \ldots \ldots \ldots \ldots$

8. DESCRIPTION OF THE DOCUMENTATION FILE $\ldots \ldots \ldots \ldots \ldots \ldots \ldots \ldots$

9. DESCRIPTION, FORMAT, AND PARTIAL LISTINGS OF THE ASCII DATA FILES . . . . 9

10. DESCRIPTION AND FORMAT OF THE LOTUS 1-2-3 BINARY SPREADSHEET FILES

11. SAS@ AND FORTRAN CODES TO ACCESS THE DATA $\ldots \ldots \ldots \ldots \ldots \ldots \ldots \ldots$

APPENDIX A: SPECIES INCLUDED IN DATABASE $\ldots \ldots \ldots \ldots \ldots \ldots \ldots \ldots \ldots$ A-1

APPENDIX B: FULL LISTING OF REFS.DAT (FILE 4) $\ldots \ldots \ldots \ldots \ldots \ldots \ldots \ldots$ B-1

APPENDIX C: FULL LISTING OF COMMENTS.DAT (FILE 6) $\ldots \ldots \ldots \ldots \ldots \ldots$ C-1

APPENDIX D: REPRINT OF PERTINENT LITERATURE $\ldots \ldots \ldots \ldots \ldots \ldots \ldots \ldots$ D-1

A meta-analysis of elevated $\mathrm{CO}_{2}$ effects on woody plant mass, form, and physiology,

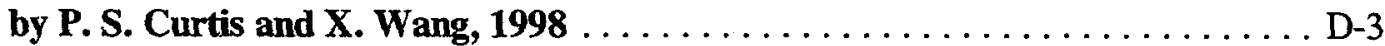





\begin{abstract}
Curtis, P. S., R. M. Cushman, and A. L. Brenkert. 1999. A Database of Woody Vegetation Responses to Elevated Atmospheric $\mathrm{CO}_{2}$. ORNL/CDIAC-120, NDP-072. Carbon Dioxide Information Analysis Center, U.S. Department of Energy, Oak Ridge National Laboratory, Oak Ridge, Tennessee, U.S.A. 63 pp.
\end{abstract}

To perform a statistically rigorous meta-analysis of research results on the response by woody vegetation to increased atmospheric $\mathrm{CO}_{2}$ levels, a multiparameter database of responses was compiled. Eighty-four independent $\mathrm{CO}_{2}$-enrichment studies, covering 65 species and 35 response parameters, met the necessary criteria for inclusion in the database: reporting mean response, sample size, and variance of the response (either as standard deviation or standard error). Data were retrieved from the published literature and unpublished reports.

This numeric data package contains a 29-field data set of $\mathrm{CO}_{2}$-exposure experiment responses by woody plants (as both a flat ASCII file and a spreadsheet file), files listing the references to the $\mathrm{CO}_{2}$-exposure experiments and specific comments relevant to the data in the data set, and this documentation file (which includes $\mathrm{SAS}_{{ }^{1}}{ }^{\mathrm{a}}$ and Fortran codes to read the ASCII data file).

The data files and this documentation are available without charge on a variety of media and via the Internet from the Carbon Dioxide Information Analysis Center (CDIAC).

NDP-072 is an enhancement of previously published CDIAC DB-1018, with additional quality control and documentation (and some corrections to the data, detailed herein).

Keywords: carbon dioxide, meta-analysis, vegetation

${ }^{1}$ SAS® is a registered trademark of the SAS Institute, Inc., Cary, North Carolina 27511. 


\section{BACKGROUND INFORMATION}

To perform a statistically rigorous synthesis of research results on the response by vegetation to increased atmospheric $\mathrm{CO}_{2}$ levels, a multiparameter database of woody-plant responses was compiled (Curtis 1996; Curtis and Wang 1998, included in this report as Appendix D). Eighty-four independent $\mathrm{CO}_{2}$-enrichment studies, covering 65 species (listed in Appendix A) and 35 response parameters, met the necessary criteria for inclusion in the database: reporting mean response, sample size, and variance of the response (either as standard deviation or standard error). Data were retrieved from the published literature and in a few instances from unpublished reports. Meta-analytical methods (Cooper and Hedges 1994; Gurevitch and Hedges 1993; Gurevitch et al. 1992) have been applied to part of this database (Curtis 1996; Curtis and Wang 1998).

Physiological "acclimation" or "downward regulation" of photosynthetic rates, stomatal conductance, dark respiration, and water-use efficiency of plants exposed to elevated $\mathrm{CO}_{2}$ levels can be analyzed, keeping the following definitions in mind. "Acclimation" is in general defined as "diminishing enhancement of photosynthesis by elevated $\mathrm{CO}_{2}$ with time" (Mousseau and Saugier 1992). "Downward regulation" can be defined as "the initial stimulation of enhanced photosynthesis and growth by atmospheric enrichment eroding with time" (Idso and Kimball 1992). The phenomenon is also called "downward acclimation" (Curtis and Teeri 1992):

"following prolonged exposure to high $\mathrm{CO}_{2}$, photosynthetic capacity measured at either elevated or ambient $\mathrm{CO}_{2}$ partial pressure falls to below that of plants exposed only to ambient $\mathrm{CO}_{2}$." When more than one elevated $\mathrm{CO}_{2}$ treatment level was reported, only the elevated $\mathrm{CO}_{2}$ level that was approximately twice the ambient level was included in the database. Only the longest lasting exposure experiment results on photosynthetic rates, stomatal conductance, dark respiration and water use efficiency are included, however, not multiple measurements over time from the same plant. And only responses of plants measured at elevated levels of $\mathrm{CO}_{2}$ are included for evaluation of acclimatory responses. Durations of experimental exposures are always reported.

\section{APPLICATIONS OF THE DATA}

This database was produced to support a meta-analysis of the effects of elevated $\mathrm{CO}_{2}$ on woody vegetation (Curtis 1996; Curtis and Wang 1998), and it was formatted accordingly. For other applications, the user should be aware that the data may be reported in more than one unit for a given variable (e.g., for dark respiration, the data are reported in units of $\mathrm{mg} / \mathrm{g} / \mathrm{d}, \mathrm{mmol} / \mathrm{g} / \mathrm{h}$, $\mathrm{mmol} / \mathrm{m}^{2} / \mathrm{h}, \mu \mathrm{mol} / \mathrm{g} / \mathrm{s}$, and $\mu \mathrm{mol} / \mathrm{m}^{2} / \mathrm{s}$; and the experimental $\mathrm{CO}_{2}$ concentrations are reported in units of $\mathrm{cm}^{3} / \mathrm{m}^{3}, \mathrm{~Pa}, \mathrm{ppm}, \mu \mathrm{bar}, \mu \mathrm{l} / \mathrm{l}$, and $\mu \mathrm{mol} / \mathrm{mol}$ ); this is not a problem for meta-analysis, but for other applications the user may need to convert the data to consistent units. 
The effects of environmental factors (e.g., nutrient levels, light intensity, temperature), stress treatments (e.g., drought, heat, ozone, ultraviolet- $\mathrm{B}$ radiation), and the effects of experimental conditions (e.g., duration of $\mathrm{CO}_{2}$ exposure, pot size, type of $\mathrm{CO}_{2}$ exposure facility) on plant responses to elevated $\mathrm{CO}_{2}$ levels can be explored with this database.

\section{DATA LIMITATIONS AND RESTRICTIONS}

In many papers, the data were reported graphically, rather than numerically. In such cases, the data values reported herein were digitized from the printed figures and may therefore be less accurate.

There might also have been some confusion because of the term "standard deviation." When a "standard deviation" was reported in a published paper, it was not generally possible to verify whether this value was a sample standard deviation or the standard deviation of the mean, which is sometimes used synonymously with standard error (i.e., standard error of the mean). Unfortunately, it was not possible to settle this issue definitively without personally contacting the authors of the published papers. In all cases, where not specified or known to be otherwise, a reported standard deviation was taken to be the sample standard deviation. If this was in error, then the standard deviation, standard error, and coefficient of variation reported in this database would all be incorrect.

In some cases an error bar in a figure or confidence interval in a table was not specified as standard deviation or standard error, in which case the data contributors had to make an assumption from the error bar or confidence interval and the sample size. Instances where data were obtained by personal communication with the authors, or where standard deviation or standard error was inferred from the published data, are documented in the comments.* files (included as Appendix C). Where it was not possible to determine whether the reported variability was standard deviation or standard error, it was assumed to be standard error, for the sake of conservatism.

In some cases (e.g., in long-term exposures), duration of the $\mathrm{CO}_{2}$ exposure was approximated.

As noted in Sect. 2, various units may be used for the same parameter, so the user should apply caution in integrating observations from more than one paper. The units are reported in this database.

\section{DATA CHECKS AND PROCESSING PERFORMED BY CDIAC}

An important part of the data packaging process at CDIAC involves the quality assurance (QA) of data before distribution. To guarantee data of the highest possible quality, CDIAC performs 
extensive QA checks, examining the data for completeness, reasonableness, and accuracy, through close cooperation with the data contributor.

This database was originally published as CDIAC DB-1018, for which all entries in the data file were visually inspected for reasonableness and selected entries were spot-checked against the original publications. Additional quality-assurance and documentation was performed in the preparation of this numeric data package, and some data were corrected, as described herein.

The following describes the additional data checks that were performed in the preparation of this numeric data package and the resulting revisions to the database.

Using Excel, the spreadsheet included in the original database (db1018.xls) was converted to Lotus 1-2-3 format (ndp072.wk1). Headings were added to all columns.

Lists of entries for each field were generated, to identify possible spelling variants, typographical errors, or order-of-magnitude errors in the original literature or in the compilation and data entry of the database. In fact, some variant spellings of GENUS, SPECIES, and P_UNIT were identified and corrected for the sake of consistency.

The definition of parameter LFTNC was corrected, from "leaf N (TNC free weight basis)" to "leaf total nonstructural carbohydrate."

The internal consistency of the reported standard errors (s.e.), standard deviations (s.d.), and sample sizes ( $\mathrm{n}$ ) was checked by calculating s.d. from the s.e. and $\mathrm{n}$ in DB-1018 and comparing the resulting values of s.d. with the values in DB-1018; discrepancies were resolved by checking the original publications.

The ratio of elev/amb for $\mathrm{X}, \mathrm{SE}, \mathrm{SD}$, and $\mathrm{N}$ was calculated; then all observations were ranked on the basis of each ratio to identify suspect values.

The following lists the changes that were made to the original database.

SOURCE: In entire spreadsheet, edited format of letters following $\mathrm{T}$ or $\mathrm{F}$ number to entirely lowercase.

OBS 39 \& 40 (PAP_NO 150): Corrected P_UNIT, from $\mathrm{molH}_{2} \mathrm{O} / \mathrm{m}^{2} / \mathrm{s}$ to $\mathrm{mmolH}{ }_{2} \mathrm{O} / \mathrm{m}^{2} / \mathrm{s}$.

OBS 142 (PAP_NO 340): Replaced existing value of SD_AMB (0.9798) with value calculated from SE_AMB \& N_AMB (2.4495).

OBS 143 \& 151 (PAP_NO 340): Corrected P_UNIT, from $0.01 \mathrm{~g} / \mathrm{m}^{2}$ to $10^{2} \mathrm{~g} / \mathrm{g}$. 
OBS 150 (PAP_NO 340): Replaced existing value of SD_AMB (3.9192) with value calculated from SE_AMB \& N_AMB (1.9596).

OBS 191 (PAP_NO 505): Corrected SOURCE, from F2b to F2c.

OBS 191 (PAP_NO 505): Replaced existing values of SD_AMB (5.134) and SD_ELEV (7.7972) with values calculated from SE \& N (SD_AMB = 10.268 and SD_ELEV = 3.487).

OBS 192 (PAP_NO 505): Replaced existing values of SD_AMB (5.367), SD_ELEV (5.747), SE_AMB (2.4), SE_ELEV (2.57), N_AMB (20), and N_ELEV (20) with values provided by author: SD_AMB (5.484), SD_ELEV (4.406), SE_AMB (2.452), SE_ELEV (1.970), N_AMB (5), and N_ELEV (5).

OBS 195 (PAP_NO 505): Corrected P_UNIT, from $\mathrm{mgdvvt} / \mathrm{cm}^{3}$ to $\mathrm{mgdwt} / \mathrm{cm}^{3}$.

OBS 210 \& 211 (PAP_NO 506): Corrected P_UNIT, from umol/ $/ \mathrm{H}_{2} \mathrm{O} / \mathrm{m}^{2} / \mathrm{s}$ to $\mathrm{mol} / \mathrm{H}_{2} \mathrm{O} / \mathrm{m}^{2} / \mathrm{s}$.

OBS 364 \& 365 (PAP_NO 746): Corrected SPECIES name from tulipfera to tulipifera.

OBS 598-599, 606-607, and 612-613 (PAP_NO 2110): Existing values for means, standard error, and standard deviation multiplied by 100 , based on personal communication from author, to correct for error in the published paper (in converting from $\%$ to $\mathrm{mg} / \mathrm{g}$, data were divided by 10 rather than multiplied by 10). Personal correspondence with author also confirmed that variance values given parenthetically in Table 2 were standard deviations; the tabulated data were corrected accordingly.

To search for possible confusion between standard error and standard deviation (see Sect. 3, DATA LIMITATIONS AND RESTRICTIONS), coefficients of variation CV* (after Sokal and Rohlf 1981) were calculated for each PARAM from each mean, standard deviation, and sample size. It was expected that, for any PARAM, an anomalously low coefficient of variation for a given observation might signal that a standard error was mislabeled as a standard deviation; but no such anomalies were obvious. The database was sorted by PARAM, then by CV*_AMB $^{*}$ and CV*_ELEV, and inspected for jumps of greater than fourfold between adjacent observations. The following lists those adjacent observations that warranted further scrutiny, along with the results of the checks:

PARAM $=\mathrm{BD}$

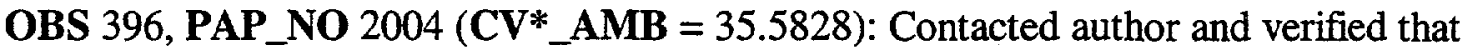
"mean \pm SD"actually referred to sample standard deviation rather than standard error of the mean.

OBS 758, PAP_NO $2224\left(\right.$ CV $\left.^{*} \_A M B=623.5\right)$ : Verified tabulated value against publication. 
PARAM = BGWT

OBS 380, PAP_NO 2003 (CV*_AMB=0) and OBS 378, PAP_NO 2003

(CV*_AMB=2.3864): Verified tabulated values against publication.

PARAM $=$ LFC

OBS 599, PAP_NO $2110\left(\mathrm{CV}^{*}\right.$ _AMB=3.2753): Personal correspondence with author confirmed that variance values given parenthetically in Table 2 were standard deviations; the tabulated data were corrected accordingly.

OBS 490, PAP_NO 2043 (CV*_AMB=16.6223): Verified tabulated value against publication.

PARAM = LFNM

OBS 414, PAP_NO 2027 (CV*_AMB=0.4532) and OBS 251, PAP_NO 550

(CV*_AMB=2.3447): Verified tabulated values against publication.

PARAM $=$ PN

OBS 513, PAP_NO 2045 (CV*_AMB=-99.0208): Verified tabulated value against publication.

OBS 638, PAP_NO $2120\left(\mathrm{CV}^{*}\right.$ _AMB=2.6460): Based on personal communication; did not verify.

PARAM $=$ PN_AC

OBS 520, PAP_NO 2045 (CV*_AMB=-99.0208) and OBS 622, PAP_NO 2117

(CV*_AMB=4.6109): Verified tabulated values against publication.

PARAM = RD_AC

OBS 589, PAP_NO 2068 (CV*_AMB=96.7737) and OBS 162, PAP_NO 468

(CV*_AMB=1073.9583): Verified tabulated values against publication.

PARAM $=$ INDLA

OBS 18, PAP_NO 44 (CV*_ELEV=10.1423) and OBS 17, PAP_NO 44

(CV*_ELEV=43.9153): Verified tabulated values against publication.

PARAM $=$ LFC

OBS 599, PAP_NO $2110\left(\mathrm{CV}^{*}\right.$ _ELEV =1.9585): Personal correspondence with author confirmed that variance values given parenthetically in Table 2 were standard deviations; the tabulated data were corrected accordingly.

OBS 490, PAP_NO 2043 (CV*_ELEV=13.8699): Corrected PARAM to LFTNC.

PARAM $=$ LFSTAR

OBS 151, PAP_NO 340 (CV*_ELEV=39.3519) and OBS 143, PAP_NO 340

(CV*_ELEV=554.3478): Verified tabulated values against publication. 
PARAM $=$ LFTNC

OBS 416, PAP_NO 2027 (CV*_ELEV=1.2777) and OBS 773, PAP_NO 2224

(CV*_ELEV=7.7891): Verified tabulated values against publication.

PARAM $=$ RD_AC

OBS 589, PAP_NO 2068 (CV*_ELEV=11.2191) and OBS 588, PAP_NO 2068

(CV*_ELEV=129.3295): Verified tabulated values against publication.

PARAM $=$ RGR

OBS 759, PAP_NO 2224 (CV*_ELEV=10.8333): Verified tabulated value against publication.

OBS $406 \&$ 407, PAP_NO 2026 (CV*_ELEV=78.1250): The value for X_ELEV was corrected, from 0.0052 to 0.052 , thereby lowering the calculated $\mathbf{C V}^{*} \_\mathbf{E L E V}$ to a less anomalous 7.8125 .

OBS 192, PAP_NO 505 (CV*_ELEV=105.7878): Tabulated data changed, as described earlier in this section, based on personal communication from author.

\section{PARAM $=$ TOTN}

OBS 613, PAP_NO $2110($ CV*_ELEV=39.0833) - Personal correspondence with author confirmed that variance values given parenthetically in Table 2 were standard deviations; the tabulated data were corrected accordingly.

OBS 243, PAP_NO 521 (CV*_ELEV=177.7945) - Error bar not labeled as to SD or $\mathrm{SE}$. Assumed by data contributor to be SE, based on size of the error bars and the sample size.

\section{INSTRUCTIONS FOR OBTAINING THE DATA AND DOCUMENTATION}

This database (NDP-072) is available free of charge from CDIAC. The files are available via the Internet, from CDIAC's World-Wide-Web site (http://cdiac.esd.ornl.gov), or from CDIAC's anonymous FTP (file transfer protocol) area (cdiac.esd.ornl.gov) as follows:

- $\quad$ FTP to cdiac.esd.ornl.gov (128.219.24.36).

- $\quad$ Enter "ftp" as the user id.

- $\quad$ Enter your electronic mail address as the password (e.g., fred@zulu.org).

- Change to the directory "pub/ndp072" (i.e., use the command "cd pub/ndp072").

- Set ftp to get ASCII files by using the ftp "ascii" command.

- Retrieve the ASCII database documentation file by using the ftp "get ndp072.txt" command.

- $\quad$ Retrieve the ASCII data files by using the ftp "mget *.dat" command.

- Set ftp to get binary files by using the ftp "binary" command.

- Retrieve the binary spreadsheet files by using the ftp "mget *.wkl" command.

- Exit the system by using the ftp "quit" command. 
Uncompress files on computer, if obtained in compressed format.

For non-Internet data acquisitions (e.g., floppy diskette or 8-mm tape), or for additional information, contact:

\section{User Services}

Carbon Dioxide Information Analysis Center

Oak Ridge National Laboratory

P.O. Box 2008

Oak Ridge, TN 37831-6335

U.S.A.

Telephone: $+1-423-574-3645$

Telefax: $+1-423-574-2232$

E-mail: cdiac@ornl.gov

Note: After 1 November 1999, the area code 423 will be changed to 865 .

\section{REFERENCES}

Cooper, H., and L. V. Hedges. 1994. The Handbook of Research Synthesis. Russell Sage Foundation, New York.

Curtis, P. S. 1996. A meta-analysis of leaf gas exchange and nitrogen in trees grown under elevated carbon dioxide. Plant, Cell and Environment 19:127-137.

Curtis, P. S., and J. A. Teeri. 1992. Seasonal responses of leaf gas exchange to elevated carbon dioxide in Populus grandidentata. Canadian Journal of Forest Research 22:1320-1325.

Curtis, P. S., and X. Wang. 1998. A meta-analysis of elevated $\mathrm{CO}_{2}$ effects on woody plant mass, form, and physiology. Oecologia 113:299-313. (Included as Appendix D in this numeric data package.)

Gurevitch, J., and L. V. Hedges. 1993. Meta-analysis: Combining the results of independent experiments. Pp. 378-398. In S. M. Scheiner and J. Gurevitch (eds.), Design and Analysis of Ecological Experiments. Chapman and Hall, New York.

Gurevitch, J., L. L. Morrow, A. Wallace, and J. S. Walsch. 1992. A meta-analysis of competition in field experiments. American Naturalist 140:539-572.

Idso, S. B., and B. A. Kimball. 1992. Effects of atmospheric $\mathrm{CO}_{2}$ enrichment on photosynthesis, respiration, and growth of sour orange trees. Plant Physiology 99:341-343. 
Mousseau, M., and B. Saugier. 1992. The direct effect of increased $\mathrm{CO}_{2}$ on gas exchange and growth of forest tree species. Joumal of Experimental Botany 43:1121-1130.

Sokal, R. R., and F. J. Rohlf. 1981. Biometry. W. H. Freeman and Company, New York.

Strain, B. R., and J. D. Cure. 1994. Direct effects of atmospheric $\mathrm{CO}_{2}$ enrichment on plants and ecosystems: An updated bibliographic database. ORNL/CDIAC-70. Carbon Dioxide Information Analysis Center, U.S. Department of Energy, Oak Ridge National Laboratory, Oak Ridge, Tennessee.

\section{LISTING OF FILES PROVIDED}

The database consists of seven files (see Table 1), including this documentation file. The data file (ndp072.dat and ndp072.wk1), reference file (refs.dat and refs.wk1), and comment file (comments.dat and comments.wk1) are each formatted in two ways: as flat ASCII files and as binary spreadsheet files (in Lotus ${ }^{2}$ 1-2-3 format, but readable by other spreadsheet programs).

The 29-field ndp072.dat and ndp072.wk1 files contain data (784 observations in all) relevant for $\mathrm{CO}_{2}$-exposure meta-analysis for woody plants. The ndp072.dat file can be read into SAS\& or Fortran programs, using the access codes provided in Sect. 11 of this numeric data package. The ndp072.dat file can also be converted into a spreadsheet file for processing, although it is simpler to use the ndp072.wk1 spreadsheet file provided in this numeric data package.

The refs.* files list the selected literature represented in the data files ( 84 references in all), and the comments.* files provide additional information about the studies, beyond what appears in the ndp072.* data files. The reference numbers in the refs.* and comments.* correspond to the paper numbers in the ndp072.* data files.

${ }^{2}$ Lotus $1-2-3$ is a registered trademark of the Lotus Development Corporation, Cambridge, Massachusetts 02142 
Table 1. Data files in the database

\begin{tabular}{lllll}
\hline $\begin{array}{c}\text { File } \\
\text { number }\end{array}$ & \multicolumn{1}{c}{ File name } & $\begin{array}{c}\text { File size } \\
(\mathrm{kB})\end{array}$ & \multicolumn{1}{c}{ File type } & \multicolumn{1}{c}{ File description } \\
\hline 1 & ndp072.txt & 81 & ASCII text & Documentation file \\
2 & ndp072.dat & 185 & ASCII text & Data file \\
3 & ndp072.wk1 & 392 & Binary spreadsheet & Data file \\
4 & refs.dat & 18 & ASCII text & Reference file \\
5 & refs.wk1 & 21 & Binary spreadsheet & Reference file \\
6 & comments.dat & 24 & ASCII text & Comment file \\
7 & comments.wk1 & 25 & Binary spreadsheet & Comment file \\
\hline
\end{tabular}

\section{DESCRIPTION OF THE DOCUMENTATION FILE}

ndp072.txt (File 1)

This file is an ASCII text equivalent to this document.

\section{DESCRIPTION, FORMAT, AND PARTIAL LISTINGS OF THE ASCII DATA FILES} ndp072.dat (File 2)

Table 2 describes the format and contents of the ASCII data file ndp072.dat distributed with this numeric data package. This table also indicates the column in the corresponding spreadsheet file ndp072.wk1 in which each variable is found. 
Table 2. Contents and format of ndp072.dat (File 2)

\begin{tabular}{|c|c|c|c|c|c|c|c|}
\hline Variable & $\begin{array}{c}\text { Variable } \\
\text { type }\end{array}$ & $\begin{array}{l}\text { Variable } \\
\text { width }\end{array}$ & $\begin{array}{l}\text { Starting } \\
\text { column }\end{array}$ & $\begin{array}{l}\text { Ending } \\
\text { column }\end{array}$ & Units & $\begin{array}{l}\text { Spreadsheet } \\
\text { column }\end{array}$ & $\begin{array}{l}\text { Definition and } \\
\text { comments }\end{array}$ \\
\hline OBSNO & Numeric & 3 & 1 & 3 & & A & $\begin{array}{l}\text { Observation } \\
\text { number }\end{array}$ \\
\hline PAP_NO & Numeric & 4 & 4 & 7 & See below & B & $\begin{array}{l}\text { Cited paper } \\
\text { numbers }\end{array}$ \\
\hline PARAM & Character & 6 & 8 & 13 & See below & C & $\begin{array}{l}\text { Measured } \\
\text { parameter }\end{array}$ \\
\hline P_UNIT & Character & 15 & 14 & 28 & & $\mathrm{D}$ & Unit for PARAM \\
\hline GENUS & Character & 13 & 29 & 41 & & $\mathrm{E}$ & Plant genus name \\
\hline SPECIES & Character & 25 & 42 & 66 & & F & $\begin{array}{l}\text { Plant species } \\
\text { name }\end{array}$ \\
\hline DIV1 & Character & 5 & 67 & 71 & See below & G & $\begin{array}{l}\text { Functional } \\
\text { division \#1 }\end{array}$ \\
\hline DIV2 & Character & 5 & 72 & 76 & See below & $\mathrm{H}$ & $\begin{array}{l}\text { Functional } \\
\text { division \#2 }\end{array}$ \\
\hline AMB & Character & 4 & 77 & 80 & $\begin{array}{l}\text { See } \\
\text { CO2_UNIT }\end{array}$ & I & $\begin{array}{l}\text { Ambient } \mathrm{CO}_{2} \\
\text { treatment level }\end{array}$ \\
\hline ELEV & Character & 4 & 81 & 84 & $\begin{array}{l}\text { See } \\
\mathrm{CO} 2 \_ \text {UNIT }\end{array}$ & $\mathbf{J}$ & $\begin{array}{l}\text { Elevated } \mathrm{CO}_{2} \\
\text { treatment level }\end{array}$ \\
\hline CO2_UNIT & Character & 8 & 85 & 92 & See below & $\mathbf{K}$ & $\begin{array}{l}\text { Units for } \mathrm{CO}_{2} \\
\text { exposure } \\
\text { concentration }\end{array}$ \\
\hline TIME & Numeric & 4 & 93 & 96 & Days & L & $\begin{array}{l}\text { Maximum } \\
\text { duration of } \mathrm{CO}_{2} \\
\text { exposure }\end{array}$ \\
\hline POT & Character & 6 & 97 & 102 & See below & $\mathrm{M}$ & Growing method \\
\hline METHOD & Character & 4 & 103 & 106 & See below & $\mathbf{N}$ & $\begin{array}{l}\mathrm{CO}_{2} \text {-exposure } \\
\text { facility }\end{array}$ \\
\hline STOCK & Character & 8 & 107 & 114 & See below & $\mathrm{O}$ & Planting stock \\
\hline XTRT & Character & 6 & 115 & 120 & See below & $\mathbf{P}$ & $\begin{array}{l}\text { Interacting } \\
\text { treatment }\end{array}$ \\
\hline LEVEL & Character & 7 & 121 & 127 & See below & $\mathrm{Q}$ & $\begin{array}{l}\text { Interacting } \\
\text { treatment level }\end{array}$ \\
\hline
\end{tabular}


Table 2 (continued)

\begin{tabular}{|c|c|c|c|c|c|c|c|}
\hline Variable & $\begin{array}{c}\text { Variable } \\
\text { type }\end{array}$ & $\begin{array}{l}\text { Variable } \\
\text { width }\end{array}$ & $\begin{array}{l}\text { Starting } \\
\text { column }\end{array}$ & $\begin{array}{l}\text { Ending } \\
\text { column }\end{array}$ & Units & $\begin{array}{l}\text { Spreadsheet } \\
\text { column }\end{array}$ & $\begin{array}{l}\text { Definition and } \\
\text { comments }\end{array}$ \\
\hline QUANT & Character & 24 & 128 & 151 & See below & $\mathbf{R}$ & $\begin{array}{l}\text { Quantity and unit } \\
\text { associated with } \\
\text { LEVEL }\end{array}$ \\
\hline SOURCE & Character & 6 & 152 & 157 & See below & $S$ & $\begin{array}{l}\text { Figure, table, or } \\
\text { page from which } \\
\text { data were taken }\end{array}$ \\
\hline X_AMB & Numeric & 10 & 158 & 167 & $\begin{array}{l}\text { See } \\
\text { P_UNIT }\end{array}$ & $\mathrm{T}$ & $\begin{array}{l}\text { Mean response of } \\
\text { plants grown in } \\
\text { ambient } \mathrm{CO}_{2}\end{array}$ \\
\hline SE_AMB & Numeric & 9 & 168 & 176 & $\begin{array}{l}\text { See } \\
\text { P_UNIT }\end{array}$ & $\mathrm{U}$ & $\begin{array}{l}\text { Standard error of } \\
\text { X_AMB }\end{array}$ \\
\hline SD_AMB & Numeric & 10 & 177 & 186 & $\begin{array}{l}\text { See } \\
\text { P_UNIT }\end{array}$ & $\mathrm{V}$ & $\begin{array}{l}\text { Standard } \\
\text { deviation of } \\
\text { responses of } \\
\text { plants grown in } \\
\text { ambient } \mathrm{CO}_{2}\end{array}$ \\
\hline CV*_AMB & Numeric & 9 & 187 & 195 & $\%$ & $W$ & $\begin{array}{l}\text { Coefficient of } \\
\text { variation of } \\
\text { responses of } \\
\text { plants grown in } \\
\text { ambient } \mathrm{CO}_{2}\end{array}$ \\
\hline N_AMB & Numeric & 3 & 196 & 198 & & $\mathrm{X}$ & $\begin{array}{l}\text { Sample size of } \\
\text { responses of } \\
\text { plants grown in } \\
\text { ambient } \mathrm{CO}_{2}\end{array}$ \\
\hline X_ELEV & Numeric & 10 & 199 & 208 & $\begin{array}{l}\text { See } \\
\text { P_UNIT }\end{array}$ & $\mathbf{Y}$ & $\begin{array}{l}\text { Mean response of } \\
\text { plants grown in } \\
\text { elevated } \mathrm{CO}_{2}\end{array}$ \\
\hline SE_ELEV & Numeric & 9 & 209 & 217 & $\begin{array}{l}\text { See } \\
\text { P_UNIT }\end{array}$ & $\mathrm{Z}$ & $\begin{array}{l}\text { Standard error of } \\
\text { X_ELEV }\end{array}$ \\
\hline SD_ELEV & Numeric & 10 & 218 & 227 & $\begin{array}{l}\text { See } \\
\text { P_UNIT }\end{array}$ & $\mathrm{AA}$ & $\begin{array}{l}\text { Standard } \\
\text { deviation of } \\
\text { responses of } \\
\text { plants grown in } \\
\text { elevated } \mathrm{CO}_{2}\end{array}$ \\
\hline
\end{tabular}


Table 2 (continued)

\begin{tabular}{|c|c|c|c|c|c|c|c|}
\hline Variable & $\begin{array}{l}\text { Variable } \\
\text { type }\end{array}$ & $\begin{array}{l}\text { Variable } \\
\text { width }\end{array}$ & $\begin{array}{l}\text { Starting } \\
\text { column }\end{array}$ & $\begin{array}{l}\text { Ending } \\
\text { column }\end{array}$ & Units & $\begin{array}{l}\text { Spreadsheet } \\
\text { column }\end{array}$ & $\begin{array}{l}\text { Definition and } \\
\text { comments }\end{array}$ \\
\hline CV*_ELEV & Numeric & 9 & 228 & 236 & $\%$ & $\mathrm{AB}$ & $\begin{array}{l}\text { Coefficient of } \\
\text { variation of } \\
\text { responses of } \\
\text { plants grown in } \\
\text { elevated } \mathrm{CO}_{2}\end{array}$ \\
\hline N_ELEV & Numeric & 3 & 237 & 239 & & $\mathrm{AC}$ & $\begin{array}{l}\text { Sample size of } \\
\text { responses of } \\
\text { plants grown in } \\
\text { elevated } \mathrm{CO}_{2}\end{array}$ \\
\hline
\end{tabular}

Where:

For PAP_NO, a value $<2000$ indicates abstracts in Strain and Cure (1994), and a value $>2000$ indicates more recent literature.

For PARAM, the following define the possible measured parameters:

plant parts

AGWT: total aboveground weight

BD: basal diameter

BGWT: total belowground weight

CRWT: coarse root weight

FRWT: fine root weight

HT: height

LFWT: total leaf weight

RGR: relative growth rate

SEEDWT: reproductive biomass

STWT: stem weight

TOTWT: whole plant weight

leaf area components

INDLA: maximum individual leaf area

LAR: leaf area ratio (leaf area/unit mass of plant)

MAXLA: maximum canopy leaf area

SLA: specific leaf area (leaf area/unit mass of leaf)

SLW: specific leaf weight (leaf mass/unit area of leaf)

gas-exchange parameters 
GS: stomatal conductance of ambient plants measured under ambient $\mathrm{CO}_{2}\left(\mathbf{X} \_\mathrm{AMB}\right)$ and elevated plants measured under elevated $\mathrm{CO}_{2}$ levels (X_ELEV)

GS_AC: stomatal conductance of ambient plants measured at elevated $\mathrm{CO}_{2}\left(\mathbf{X} \_\mathbf{A M B}\right)$ and elevated plants measured at elevated $\mathrm{CO}_{2}$ levels (X_ELEV)

JMAX: maximum rate of electron transport

PIRC: rate of phosphate regeneration

PN: net $\mathrm{CO}_{2}$ assimilation of ambient plants measured under ambient $\mathrm{CO}_{2}\left(\mathbf{X} \_\mathbf{A M B}\right)$ and elevated plants measured under elevated $\mathrm{CO}_{2}$ levels (X_ELEV)

PN_AC: net $\mathrm{CO}_{2}$ assimilation of ambient plants measured at elevated $\mathrm{CO}_{2}\left(\mathbf{X} \_\mathbf{A M B}\right)$ and elevated plants measured at elevated $\mathrm{CO}_{2}$ levels (X_ELEV)

$\mathrm{RD}$ : dark respiration of ambient plants measured under ambient $\mathrm{CO}_{2}\left(\mathbf{X} \_\mathrm{AMB}\right)$ and elevated plants measured under elevated $\mathrm{CO}_{2}$ levels (X_ELEV)

RD_AC: dark respiration of ambient plants measured at elevated $\mathrm{CO}_{2}\left(\mathbf{X} \_\mathrm{AMB}\right)$ and elevated plants measured at elevated $\mathrm{CO}_{2}$ levels (X_ELEV)

VCMAX: maximum carboxylation rate of Rubisco

WUE: water use efficiency of ambient plants measured under ambient $\mathrm{CO}_{2}\left(\mathbf{X} \_\mathbf{A M B}\right)$ and elevated plants measured under elevated $\mathrm{CO}_{2}$ levels (X_ELEV)

WUE_AC: water use efficiency of ambient plants measured at elevated $\mathrm{CO}_{2}\left(\mathbf{X} \_\mathbf{A M B}\right)$ and elevated plants measured at elevated $\mathrm{CO}_{2}$ levels (X_ELEV)

biochemical constituents

LFC: leaf total C (unit mass basis)

LFNA: leaf $\mathrm{N}$ (unit area basis)

LFNM: leaf $\mathrm{N}$ (unit mass basis)

LFTNC: leaf total non-structural carbohydrate

LFP: leaf P (unit mass basis)

LFSTAR: leaf starch (unit mass basis)

LFSUG: leaf sugar (unit mass basis)

TOTN: total N (concentration)

The value of PARAM is linked to that shown for P_UNIT (parameter units), $\mathbf{X} \_$AMB (parameter value for plants grown under ambient $\mathrm{CO}_{2}$ exposure conditions), and $\mathbf{X} \_\mathbf{E L E V}$ (parameter value for plants grown under elevated $\mathrm{CO}_{2}$ exposure conditions).

All entries for DIV1 are "WOODY" in this database.

Entries for DIV2 are:

ANGIO: angiosperms

GYMNO: gymnosperms

N2FIX: nitrogen fixation by species in experiment

The values of AMB and ELEV are linked to that shown for CO2_UNIT. 
Entries for CO2_UNIT are:

$\mathrm{Pa}$ (Pascals)

$\mu \mathrm{bar}(1 \mu \mathrm{bar}=0.1 \mathrm{~Pa})$

ppm

$\mu 1 / 1$

$\mathrm{cm}^{3} / \mathrm{m}^{3}$

$\mu \mathrm{mol} / \mathrm{mol}$

For POT, a numeric entry signifies pot size (in liters) used during the major part of the experiment; the other entries are:

GRND: plants rooted in the ground

HYDRO: solution or aeroponic culture

Entries for METHOD are:

BRANCH: branch chambers

GC: indoor, controlled environment: growth chambers

GH: sunlit greenhouses and chambers within greenhouses

OTC: field-based open-top chambers

SPAR: high-tech soil-plant-atmosphere chambers

Entries for STOCK are:

BRANCH: branches exposed

MATURE: mature plants exposed

SAP: plants started from cuttings

SEED: plants started from seeds

Entries for XTRT are:

NONE: no treatment

COMP: plant competition

FERT+L: soil fertility and light

FERT: soil fertility

H2O: well-watered vs drought

LIGHT: light treatment

TEMP: temperature treatment

OZONE: ozone exposure

UVB: ultraviolet-B radiation exposure

The entries for LEVEL (which qualitatively describes the treatment level) are treatmentdependent and cannot be further categorized; this field is linked with XTRT (which characterizes the treatment type) and QUANT (which quantifies the treatment level).

For XTRT $=$ NONE, COMP, or FERT $+\mathrm{L}$, LEVEL $=$. (missing value) (see entry for corresponding paper in comments.* file) 
For soil fertility treatment:

FERT - HI

LOW

CONTROL

missing (.) when treatment can not be clearly described (see entry for corresponding paper in comments.* file).

For $\mathrm{H} 2 \mathrm{O}$ treatment:

DRT: drought

WW: well-watered

For LIGHT treatment:

HI

LOW

For TEMP treatment:

HI

LOW

CONTROL

For stress interactions:

OZONE

HI

LOW

UVB

HI

LOW

Entries for QUANT, which quantify the interacting treatment level, are treatment-dependent. The combination of quantity and unit is reported in this one field (see also the corresponding entry in comments.* file). The missing-value indicator for QUANT is a period (.).

Possible entry formats for SOURCE are:

F1a (Fig. 1a)

T1 (Table 1)

P235 (Page 235 of text)

lemeta (personal communication with authors)

Entries for X_AMB, SE_AMB, SD_AMB, X_ELEV, SE_ELEV, and SD_ELEV are linked to the units given for P_UNIT. The suffix "AMB" refers to measurements of plants grown under ambient $\mathrm{CO}_{2}$ exposure conditions, and the suffix "ELEV" refers to measurements of plants grown under elevated $\mathrm{CO}_{2}$ exposure conditions. 
For CV*_AMB and CV*_ELEV, corrected (for small sample size) coefficient of variation was calculated according to Sokal and Rohlf (1981) as follows:

$$
C V^{*}=(1+1 / 4 \mathrm{~N})(\mathrm{SD} \times 100) / \mathrm{X}
$$

where $\mathrm{SD}=$ standard deviation, $\mathrm{X}=$ mean, and $\mathrm{N}=$ sample size.

First two data records:

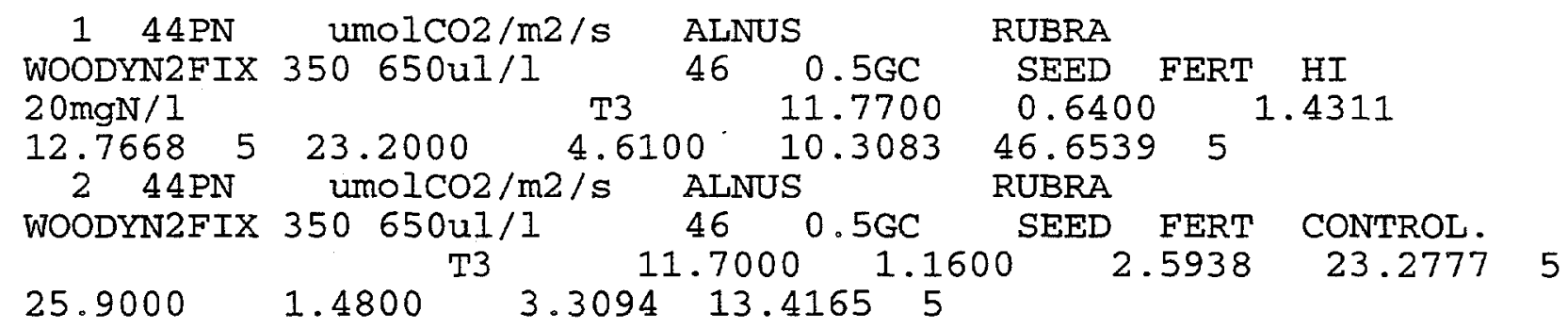

Last two data records:

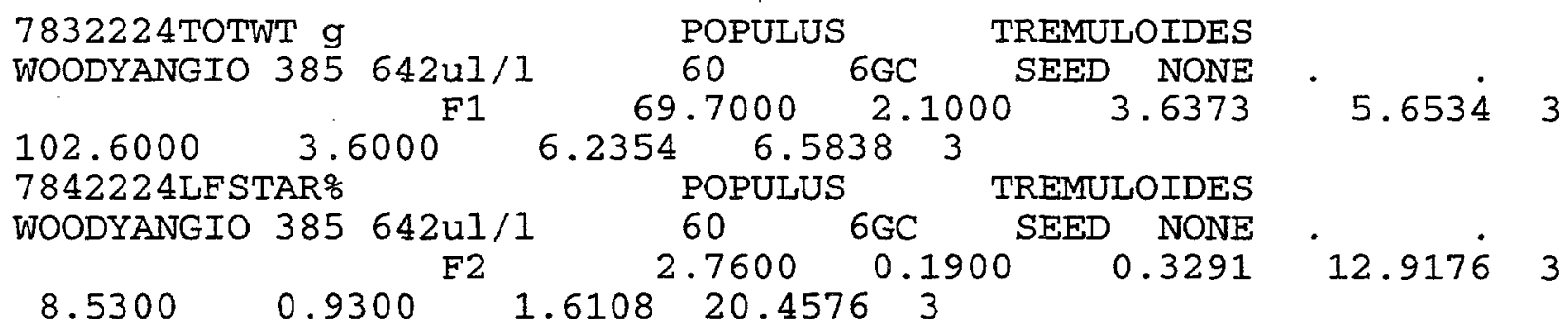

refs.dat (File 4)

This ASCII file provides citations of papers included in the database. A full listing of the file is included as APPENDIX B.

\section{comments.dat (File 6)}

This ASCII file provides experimental details from papers included in the database. A full listing of the file is included as APPENDIX C. 


\section{DESCRIPTION AND FORMAT OF THE LOTUS 1-2-3 BINARY SPREADSHEET FILES}

Three Lotus 1-2-3 binary spreadsheet files (files 3, 5, and 7) contain the same information as the corresponding *.dat ASCII files 2, 4, and 6.

\section{ndp072.wk1 (File 3)}

This Lotus 1-2-3 binary spreadsheet file corresponds to ASCII file ndp072.dat (File 2). Table 2, which describes the contents and format of ndp072.dat, also indicates the column of ndp072.wk1 in which each variable is found.

refs.wk1 (File 5)

This Lotus 1-2-3 binary spreadsheet file corresponds to ASCII file refs.dat (File 4).

comments.wk1 (File 7)

This Lotus 1-2-3 binary spreadsheet file corresponds to ASCII file comments.dat (File 6).

\section{SAS@ AND FORTRAN CODES TO ACCESS THE DATA}

The following is SASß code to read file ndp072.dat

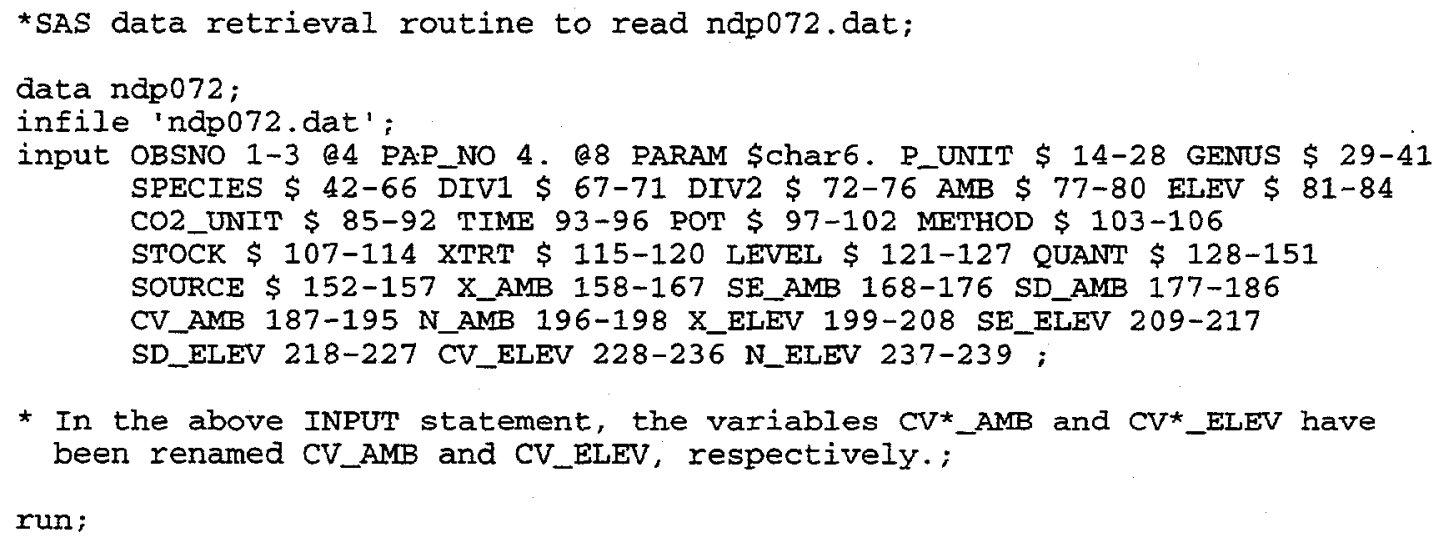

The following is Fortran code to read file ndp072.dat

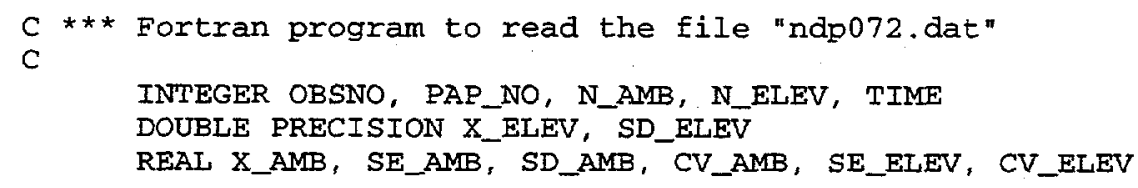


CHARACTER PARAM*6, P_UNIT*15, GENUS*13， SPECIES*25，DIV1*5，

$+\mathrm{DIV} 2 * 5, \mathrm{AMB}^{*} 4, \operatorname{ELEV} * 4, \mathrm{CO} 2 \_\mathrm{UNIT} * 8, \mathrm{POT} * 6, \mathrm{METHOD} 4, \mathrm{STOCK} * 8$,

$\mathrm{C}$

$+\mathrm{XTRT} * 6$, LEVEL $* 7$, QUANT $* 24$, SOURCE $* 6$

C

OPEN (UNIT $=1$, FILE $=$ 'NDP072.DAT')

C

C

10 READ $(1,100$, END=99) OBSNO, PAP_NO, PARAM, P_UNIT, GENUS, SPECIES,

+ DIVI, DIV2, AMB, ELEV, CO2_UNIT, TIME, POT, METHOD, STOCK, XTRT,

+ IEVEL, QUANT, SOURCE, X_AMB， SE_AMB， SD_AMB , CV_AMB, N_AMB , X_ELEV,

+ SE_ELEV, SD_ELEV, CV_ELEV, N_ELEV

100 FORMAT (I3, I $4, A 6, A 15, \bar{A} 13, \mathrm{~A} 25, \overline{2} \mathrm{~A} 5,2 \mathrm{~A} 4, \mathrm{~A} 8, \mathrm{~A} 4, \mathrm{~A} 6, \mathrm{~A} 4, \mathrm{~A} 8, \mathrm{~A} 6, \mathrm{~A} 7, \mathrm{~A} 24$,

$+\mathrm{A} 6, \mathrm{~F} 9.4,1 \mathrm{X}, \mathrm{F} 8.4,1 \mathrm{X}, 2(\mathrm{~F} 9.4,1 \mathrm{X}), \mathrm{I} 2,3$ (F9.4,1X), F8.4, 1X, I2)

$\mathrm{C}$

GO TO 10

99 CLOSE (UNIT=1)

STOP

END 


\section{APPENDIX A: SPECIES INCLUDED IN DATABASE}

Acacia mangium

Acer pensylvanicum

Acer pseudoplatanus

Acer rubrum

Acer saccharinum

Acer saccharum

Alnus glutinosa

Alnus rubra

Betula alleghaniensis

Betula lenta

Betula papyrifera

Betula pendula

Betula populifolia

Betula pubescens

Brachychiton populneum

Castanea sativa

Cecropia obtusifolia

Cedrus atlantica

Citrus aurantium

Citrus sinensis

Eucalyptus microtheca

Eucalyptus polyanthemus

Eucalyptus tetrodonta

Fagus grandifolia

Fagus sylvatica

Ficus obtusifolia

Fraxinus americana

Garcinia mangostana

Gliricidia sepium

Lindera Benzoin

Liquidambar styraciflua

Liriodendron tulipifera

Malus domestica

Maranthes corymbosa

Myriocarpa longipes

Nothofagus fusca

Picea abies

Picea glauca

Picea mariana

Pinus banksiana
Pinus echinata

Pinus eldarica

Pinus nigra

Pinus ponderosa

Pinus radiata

Pinus strobus

Pinus sylvestris

Pinus taeda

Piper auritum

Poncirus trifoliata $\mathrm{x}$ citrusparadisi

Poncirus trifoliata $\mathrm{x}$ citrussinensis

Populus euramericana

Populus grandidentata

Populus interamericana

Populus tremuloides

Populus x euramericana

Pseudotsuga menziesii

Quercus alba

Quercus prinus

Quercus robur

Quercus rubra

Senna multijuga

Tabebuia rosea

Trichospermum mexicanum 


\section{APPENDIX B: FULL LISTING OF REFS.DAT (FILE 4)}

The number at the beginning of each entry corresponds to PAP_NO, the cited paper number, as defined in Sect. 9.

44 Arnone, J.A., III, and J.C. Gordon. 1990. Effect of Nodulation, Nitrogen Fixation and $\mathrm{CO} 2$ Enrichment on the Physiology, Growth and Dry Mass Allocation of Seedlings of Alnus rubra Bong. New Phytologist 116:55-66.

2186 Bassow, S.I., K.D.M. McConnaughay, and F.A. Bazzaz. 1994. The Response of Temperate Tree Seedlings Grown in Elevated $\mathrm{CO} 2$ to Extreme Temperature Events. Ecological Applications 4(3):593-603.

2223 Bazzaz, F.A., and S.I. Miao. 1993. Successional Status, Seed Size, and Responses of Tree Seedlings to $\mathrm{CO} 2$, Light and Nutrients. Ecology $74(1): 104-112$.

2037 Bazzaz, F.A., S.L. Miao, and P.M. Wayne. 1993. CO2-induced Growth Enhancements of Co-occurring Tree Species Decline at Different Rates. Oecologia $96: 478-482$.

2217 Berryman, C.A., D. Eamus, and G.A. Duff. 1993. The Influence of CO2 Enrichment on Growth, Nutrient Content and Biomass Allocation of Maranthes corymbosa. Australian Journal of Botany 41:195-209.

112 Brown, K.R. 1991. Carbon Dioxide Enrichment Accelerates the Decline in Nutrient Status and Relative Growth Rate of Populus tremuloides Michx. Seedlings. Tree Physiology 8:161-173.

121 Bunce, J.A. 1992. Stomatal Conductance, Photosynthesis and Respiration of Temperate Deciduous Tree Seedlings Grown Outdoors at an Elevated Concentration of Carbon Dioxide. Plant, Cell and Environment 15:541-549.

2026 Callaway, R.M., E.H. Delucia, E.M. Thomas, and W.H. Schlesinger. 1994. Compensatory Responses of $\mathrm{CO} 2$ Exchange and Biomass Allocation and their Effects on the Relative Growth Rate of Ponderosa Pine in Different $\mathrm{CO} 2$ and Temperature Regimes. Oecologia 98:159-166.

2043 Cipollini, M.I., B.G. Drake, and D. Whigham. 1993. Effects of ElevatedCO2 on Growth and Carbon/Nutrient Balance in the Deciduous woody Shrub Lindera Benzoin (L.) Blume (Lauraceae). Oecologia 96:339-346.

150 Conroy, J.P., M. Kuppers, B. Kuppers, J. Virgona, and E.W.R. Barlow. 1988. The Influence of CO2 Enrichment, Phosphorus Deficiency and water Stress on the Growth, Conductance and water Use of Pinus radiata D. Don. Plant, Cell and Environment 11:91-98.

159 Couteaux, M.M., P. Bottner, H. Rouhier, and G. Billes. 1992. Atmospheric $\mathrm{CO} 2$ Increase and Plant Material Quality: Production, Nitrogen Allocation and Litter Decomposition of Sweet Chestnut. IN: Responses of Forest Ecosystems to Environmental Changes (A. Teller, P. Mathy, and J.N.R. Jeffers, eds.), Elsevier Applied Science, London, pp. 429-436. 
168 Curtis, P.S., and J.A. Teeri. 1992. Seasonal Responses of Leaf Gas Exchange to Elevated Carbon Dioxide in Populus grandidentata. Canadian Journal of Forest Research $22: 1320-1325$.

2039 Curtis, P.S., C.S. Vogel, K.S. Pregitzer, D.R. Zak, and J.A. Teeri. 1995. Interacting Effects of Soil Fertility and Atmospheric CO2 on Leaf Area Growth and Carbon Gain Physiology in Populus $x$ euramericana (Dode) Guinier. New Phytologist 129:253-263.

2129 Curtis, P.S., D.R. Zak, K.S. Pregitzer, and J.A. Teeri. 1994. Above- and Belowground Response of Populus grandidentata to Elevated Atmospheric $\mathrm{CO} 2$ and Soil N Availability. Plant and Soil 165:45-51.

184 Downton, W.J.S., W.J.R. Grant, and E.K. Chacko. 1990. Effect of Elevated Carbon Dioxide on the Photosymthesis and Early growth of Mangosteen (Garcinia mangostana L.). Scientia Horticulturae 44:215-225.

183 Downton, W.J.S., W.J.R. Grant, and B.R. Loveys. 1987. Carbon Dioxide Enrichment Increases Yield of Valencia Orange. Australian Journal of Plant Physiology 14:493-501.

2047 Eamus, D., C.A. Berryman, and G.A. Duff. 1993. Assimilation, Stomatal Conductance, Specific Leaf Area and Chlorophyll Responses to Elevated CO2 of Maranthes corymbosa a Tropical Rain Forest Species. Australian Journal of Plant Physiology 20:741-755.

2071 Eamus, D., C.A. Berryman, and G.A. Duff. 1995. The Impact of CO2 Enrichment on Water Relations in Maranthes corymbosa and Eucalyptus tetrodonta. Australian Journal of Botany 43:273-282.

2070 Eamus, D., G.A. Duff, and C.A. Berryman. 1995. Photosynthetic Responses to Temperature, Light, Flux-density, $\mathrm{CO} 2$ Concentration and Vapour Pressure Deficit in Eucalyptus tetrodonta Grown under $\mathrm{CO} 2$ Enrichment. Environmental Pollution 90:41-49.

208 El Kohen, A., J.-Y. Pontailler, and M. Mousseau. 1991. Effect of Doubling of Atmospheric $\mathrm{CO} 2$ Concentration on Dark Respiration in Aerial Parts of Young Chestnut Trees (Castanea sativa Mill.). Comptes Rendus des Sciences (Paris) t. 312, serie III:477-481.

209 El Kohen, A., H. Rouhier, and M. Mousseau. 1992. Changes in Dry weight and Nitrogen Partitioning Induced by Elevated $\mathrm{CO} 2$ Depends on Soil Nutrient Availability in Sweet Chestnut (Castanea sativa Mill.). Annales des Sciences Forestieres $49: 83-90$.

210 E1 Kohen, A., L. Venet, and M. Mousseau. 1993. Growth and Photosynthesis of Two Deciduous Forest Species at Elevated Carbon Dioxide. Functional Ecology $7: 480-486$.

221 Ferguson, J.J., W.T. Avigne, L.H. Allen, and K.E. Koch. 1986. Growth of CO2-enriched Sour Orange Seedlings Treated with Gibberellins/Cytokinins. Proceedings of the Florida State Horticultural Society 99:37-39.

222 Fetcher, N., C.H. Jaeger, B.R. Strain, and N. Sionit. 1988. Long-term Elevation of Atmospheric $\mathrm{CO} 2$ Concentration and the Carbon Exchange Rates of Saplings of Pinus taeda $\mathrm{L}$. and Liquidambar styraciflua I. Tree Physiology $4: 255-262$. 
2041 Garcia, R.I., S.B. Idso, G.W. Wall, and B.A. Kimball. 1994. Changes in net Photosynthesis and Growth of Pinus eldarica Seedlings in Response to Atmospheric CO2 Enrichment. Plant, Cell and Environment 17:971-978.

233 Gaudillere, J.-P., and M. Mousseau. 1989. Short Term Effect of CO2 Enrichment on Leaf Development and Gas Exchange of Young Poplars (Populus euramericana CV I 214). Acta Oecologica/Oecologia Plantarum 10:95-105.

2002 Gorissen, A., P.J. Kuikman, and H. van de Beek. 1995. Carbon Allocation and water Use in Juvenile Douglas Fir under Elevated $\mathrm{CO}$. New Phytologist $129: 275-282$.

2036 Grulke, N.E., J.L. Hom, and S.W. Roberts. 1993. Physiological Adjustment of two Full-sib Families of Ponderosa Pine to Elevated CO2. Tree Physiology $12: 391-401$.

2035 Gunderson, C.A., R.J. Norby, and S.D. Wullschleger. 1993. Foliar Gas Exchange Responses of two Deciduous Hardwoods during 3 Years of Growth in Elevated CO2: no Loss of Photosynthetic Enhancement. Plant, Cell and Environment 16:797-807.

290 Hollinger, D.Y. 1987. Gas Exchange and Dry Matter Allocation Responses to Elevation of Atmospheric $\mathrm{CO} 2$ Concentration in Seedlings of three Tree Species. Tree Physiology 3:193-202.

314 Idso, S.B., and B.A. Kimball. 1991. Downward Regulation of Photosynthesis and Growth at High CO2 Levels. Plant Physiology 96:990-992.

318 Idso, S.B., and B.A. Kimball. 1993. Effects of Atmospheric CO2 Enrichment on Net Photosynthesis and Dark Respiration Rates of Three AustralianTree Species. Journal of Plant Physiology 141:166-171.

313 Idso, S.B., B.A. Kimball, and S.G. Allen. 1991. CO2 Enrichment of Sour Orange Trees: 2.5 Years into a Long-term Experiment. Plant, Cell and Environment 14:351-353.

322 Idso, S.B., B.A. Kimball, and S.G. Allen. 1991. Net Photosynthesis of Sour Orange Trees Maintained in Atmospheres of Ambient and Elevated $\mathrm{CO} 2$ Concentration. Agricultural and Forest Meteorology 54:95-101.

2123 Jarvis, P.G., H.S.J. Lee, and C.V.M. Barton. 1994. The Likely Impact of rising $\mathrm{CO} 2$ and Temperature on European Forests. Institute of Ecology. and Resource Management, University of Edinburgh.

2045 Johnsen, K.H. 1993. Growth and Ecophysiological Responses of Black Spruce seedlings to Elevated $\mathrm{CO} 2$ under varied water and Nutrient Additions. Canadian Journal of Forest Research 23:1033-1042.

2109 Johnson, D., D. Geisinger, R. Walker, J. Newman, J. Vose, K. Elliot, and T. Ball. 1994. Soil pCO2, Soil Respiration, and Root Activity in CO2-fumigated and Nitrogen-fertilized Pondersosa Pine. Plant and Soil 165:129-138.

340 Kaushal, P., J.M. Guehl, and G. Aussenac. 1989. Differential Growth Response to Atmospheric Carbon Dioxide Enrichment in Seedlings of Cedrus atlantica and Pinus nigra ssp. Laricio var. Corsicana. Canadian Journal of Forest Research 19:1351-1358. 
362 Koch, K.E., P. Jones, W.T. Avigne, and L.H. Allen Jr. 1986. Growth, Dry Matter Partitioning, and Diurnal Activities of RuBP Carboxylase in Citrus Seedlings Maintained at Two Levels of CO2. Physiologia Plantarum $67: 477-484$.

2121 Kubiske, M.E., and K.S. Pregitzer. 1994. Effect of Elevated CO2 and Light Availability on the Photosynthetic Light Response of Trees of Contrasting Shade Tolerance. Tree Physiology; in press.

2120 Laboratorium Voor Plantecologie. 1992. Effect of Increased Atmospheric $\mathrm{CO} 2$ Concentration on Primary Productivity and Carbon Allocation in Typical Belgian Forest Ecosystems. Progress report 1992.

2028 Lavola, A., and R. Julkunen-Tiitto. 1994. The Effect of Elevated Carbon Dioxide and Fertilization on Primary and Secondary Metabolites in Birch, Betula pendula (Roth). Decologia 99:315-321.

2165 Lewis, J.D., R.B. THomas, and B.R. Strain. 1994. Effect of Elevated CO2 on Mycorrhizal Colonization of Loblolly Pine (Pinus taeda L.) Seedlings. Plant and Soil 165:81-88.

2224 Lindroth, R.L., K.K. Kinney, and C.L. Platz. 1993. Responses of Deciduous Trees to Elevated Atmospheric CO2: Productivity, Phytochemistry, and Insect Performance. Ecology $74(3): 763-777$.

2065 Liu, S., and R.O. Teskey. 1995. Responses of Foliar Gas Exchange to Long-term Elevated $\mathrm{CO} 2$ Concentrations in Mature Loblolly Pine Trees. Tree Physiology 15:351-359.

2069 Marek, M.V., J. Kalina, and M. Matouskova. 1995. Response of Photosynthetic Carbon Assimilation of Norway Spruce Exposed to Long-term Elevation of $\mathrm{CO} 2$ Concentration. Photosynthetica 31:209-220.

2117 Mortensen, L.M. 1994. Effects of Carbon Dioxide Concentration on Assimilate Partitioning, Photosynthesis and Transpiration of Betula pendula Roth. and Picea abies (L.) Karst. Seedlings at two Temperatures. Acta Agriculturae Scandinavica, Section $B$, Soil and Plant Sciences 44:164-169.

2003 Mortensen, L.M. 1995. Effect of Carbon Dioxide Concentration on Biomass Production and Partitioning in (Betula pubescens Ehrh.) Seedlings at Different Ozone and Temperature Regimes. Environmental Pollution 87:337-343.

468 Mousseau, M. 1993. Effects of Elevated CO2 on Growth, Photosynthesis and Respiration of Sweet Chestnut (Castanea sativa Mill.). Vegetatio 104/105: 413-419.

470 Mousseau, M., and H.Z. Enoch. 1989. Carbon Dioxide Enrichment Reduces Shoot Growth in Sweet Chestnut Seedlings (Castanea sativa Mill.). Plant, Cell and Environment 12:927-934.

502 Norby, R.J., C.A. Gunderson, S.D. Wullschleger, E.G. O'Neill, and M.K. McCracken. 1992. Productivity and Compensatory Responses of Yellow-poplar Trees in Elevated CO2. Nature 357:322-324.

505 Norby, R.J., and E.G. O'Neil1. 1989. Growth Dynamics and Water Use of Seedlings of Quercus alba L. in $\mathrm{CO} 2$-enriched Atmospheres. New Phytologist $111: 491-500$. 
506 Norby, R.J., and E.G. O'Neill. 1991. Leaf Area Compensation and Nutrient Interactions in CO2-enriched seedlings of Yellow-poplax (Liriodendron tulipifera L.). New Phytologist 117:515-528.

503 Norby, R.J., E.G. O'Neill, W.G. Hood, and R.J. Luxmoore. 1987. Carbon Allocation, Root Exudation and Mycorrhizal Colonization of Pinus echinata Seedlings Grown under CO2 Enrichment. Tree Physiology 3:203-210.

504 Norby, R.J., E.G. O'Neill, and R.J. Luxnoore. 1986. Effects of Atmospheric $\mathrm{CO} 2$ Enrichment on the Growth and Mineral Nutrition of Quercus alba Seedlings in Nutrient-poor Soil. Plant Physiology 82:83-89.

2131 Norby, R.J., Wullschleger, and C.A. Gunderson. 1996. Tree Responses to Elevated $\mathrm{CO} 2$ and Implications for Forests. IN: Carbon Dioxide and Terrestrial Ecosystems (G.W. Koch and H.A. Mooney, eds.), Academic Press, New York, pp. $1-21$.

510 O'Neill, E.G., R.J. Luxmoore, and R.J. Norby. 1987. Increases in Mycorrhizal Colonization and Seedling Growth in Pinus echinata and Quercus alba in an Enriched $\mathrm{CO} 2$ Atmosphere. Canadian Journal of Forest Research $17: 878-883$.

521 Overdieck, D. 1990. Effects of Elevated CO2-concentration Levels on Nutrient Contents of Herbaceous and Woody Plants. IN: The Greenhouse Effect and Primary Productivity in European Agro-ecosystems; 5-10 April 1990; Wageningen, The Netherlands ( $J$. Goudriaan, H. van Keulen, and H.H. van Laar, eds.), Pudoc, Wageningen, pp. 31-37.

550 Pettersson, R., and A.J.S. MCDonald. 1992. Effects of Elevated Carbon Dioxide Concentration on Photosynthesis and Growth of Small Birch Plants (Betula pendula Roth.) at Optimal Nutrition. Plant, Cell and Environment $15: 911-919$.

2027 Pettersson, R., A.J.S. McDonald, and I. Stadenberg. 1993. Response of Small Birch Plants (Betula pendula Roth.) to Elevated $\mathrm{CO} 2$ and Nitrogen Supply. Plant, Cell and Environment 16:1115-1121.

553 Polle, A., T. Pfirrmann, S. Chakrabarti, and H. Rennenberg. 1993. The Effects of Enhanced Ozone and Enhanced Carbon Dioxide Concentrations on Biomass, Pigments and Antioxidative Enzymes in Spruce seedlings. Plant, Cell and Environment 16:311-316.

2110 Pregitzer, K.S., D.R. Zak, P.S. Curtis, M.E. Kubiske, J.A. Teeri, and C.S. Vogel. 1995. Atmospheric CO2, Soil Nitrogen and Turnover of Fine Roots. New Phytologist $129(4): 579-585$.

582 Reekie, E.G., and F.A. Bazzaz. 1989. Competition and Patterns of Resource Use among Seedlings of Five Tropical Trees Grown at Ambient and Elevated $\mathrm{CO}$. Oecologia 79:212-222.

2046 Reid, C.D., and B.R. Strain. 1994. Effects of CO2 Enrichment on Whole-plant Carbon Budget of Seedlings of Fagus grandifolia and Acer saccharum in low Irradiance. Oecologia 98:31-39.

596 Rochefort, L., and F.A. Bazzaz. 1992. Growth Response to Elevated CO2 in Seedlings of Four Co-occurring Birch Species. Canadian Journal of Forest Research $22: 1583-1587$. 
2038 Roth, S.K., and R.I. Lindroth. 1994. Effects of CO2-mediated Changes in Paper Birch and White Pine Chemistry on Gypsy Moth Performance. Oecologia $98: 133-138$.

644 Sharkey, T.D., F. Loreto, and C.F. Delwiche. 1991. High Carbon Dioxide and Sun/Shade Effects on Isoprene Emission from Oak and Aspen Tree Leaves. Plant, Cell and Environment 14:333-338.

655 Sionit, N., B.R. Strain, H. Hellmers, G.H. Riechers, and C.H. Jaeger. 1985. Long-term Atmospheric CO2 Enrichment Affects the Growth and Development of Iiquidambar styraciflua and Pinus taeda Seedlings. Canadian Journal of Forest Research 15:468-471.

666 Stewart, J.D., and J. Hoddinott. 1993. Photosynthetic Acclimation to Elevated Atmospheric Carbon Dioxide and UV Irradiation in Pinus banksiana. Physiologia Plantarum 88:493-500.

2042 Sullivan, J.H., and A.H. Teramura. 1994. The Effects of UV-B Radiation on Loblolly Pine. 3. Interaction with $\mathrm{CO} 2$ Enhancement. Plant, Cell and Environment 17:311-317.

676 Surano, K.A., P.F. Daley, J.L.J. Houpis, J.H. Shinn, J.A. Helms, R.J. Palassou, and M.P. Costella. 1986. Growth and Physiological Responses of Pinus ponderosa Dougl. ex P. Laws. to Long-term Elevated $\mathrm{CO} 2$ Concentration. Tree Physiology $2: 243-259$.

2005 Teskey, R.O. 1995. A Field Study of the Effects of Elevated CO2 on Carbon Assimilation, Stomatal Conductance and Leaf Branch Growth of Pinus taeda Trees. Plant, Cell and Environment 18:565-573.

682 Thomas, R.B., D.D. Richter, H. Ye, P.R. Heine, and B.R. Strain. 1991.Nitrogen Dynamics and Growth of Seedlings of an N-fixing Tree (Gliricidia sepium (Jacq.) Walp.) Exposed to Elevated Atmospheric Carbon Dioxide. Oecologia $88: 415-421$.

2044 Tissue, D.T., R.B. Thomas, and B.R. Strain. 1993. Long-term Effects of Elevated $\mathrm{CO} 2$ and Nutrients on Photosynthesis and Rubisco in Loblolly Pine Seedlings. Plant, Cell and Environment 16:859-865.

2032 Tschaplinski, T.J., R.J. Norby, and S.D. Wullschleger. 1993. Responses of Loblolly Pine Seedlings to Elevated $\mathrm{CO} 2$ and Fluctuating Water Supply. Tree Physiology $13: 283-296$.

2122 Voge1, C.S., and P.S. Curtis. 1995. Leaf Gas Exchange and Nitrogen Dynamics of N2-fixing, Field-grown Alnus glutinosa under Elevated Atmospheric CO2. Global Change Biology 1:55-61.

2068 Wang, K., S. Kellomaki, and K. Laitinen. 1995. Effects of Needle Age, Long-term Temperature and $\mathrm{CO} 2$ Treatments on the Photosynthesis of Scots Pine. Tree Physiology 15:211-218.

2152 Williams, R.S., D.E. Lincoln, and R.B. Thomas. 1994. Loblolly Pine Grown under Elevated $\mathrm{CO} 2$ Affects Early Instar Pine Sawfly Performance. Oecologia $98: 64-71$. 
747 Wullschleger, S.D., and R.J. Norby. 1992. Respiratory Cost of Leaf Growth and Maintenance in White Oak Saplings Exposed to Atmospheric $\mathrm{CO} 2$ Enrichment. Canadian Journal of Forest Research 22:1717-1721.

746 Wullschleger, S.D., R.J. Norby, and C.A. Gunderson. 1992. Growth and Maintenance Respiration in Leaves of Liriodendron tulipifera L. Exposed to Long-term Carbon Dioxide Enrichment in the Field. New Phytologist 21:515-523.

2004 Wullschleger, S.D., R.J. Norby, and P.J. Hanson. 1995. Growth and Maintenance Respiration in Stems of Quercus alba after Four Years of $\mathrm{CO} 2$ Enrichment. Physiologia Plantarum 93:47-54.

7J45 Wullschleger, S.D., R.J. Norby, and D.L. Hendrix. 1992. Carbon Exchange Rates, Chlorophyll Content, and Carbohydrate status of Two Forest Tree Species Exposed to Carbon Dioxide Enrichment. Tree Physiology 10:21-31.

2048 Yakimchuk, R., and J. Hoddinott. 1994. The Influence of Ultraviolet-B Light and Carbon Dioxide Enrichment on the Growth and Physiology of Seedlings of Three Conifer Species. Canadian Journal of Forest Research 24:1-8.

756 Ziska, I.H., K.P. Hogan, A.P. Smith, and B.G. Drake. 1991. Growth and Photosynthetic Response of Nine Tropical Species with Long-term Exposure to Elevated Carbon Dioxide. Oecologia 86:383-389. 


\section{APPENDIX C: FULL LISTING OF COMMENTS.DAT (FILE 6)}

The number at the beginning of each entry corresponds to PAP_NO, the cited paper number, as defined in Sect. 9.

Listed are paper numbers, authors, $\mathrm{CO}_{2}$ exposure facility, light, temperature, watering and nutrient conditions when available, location of experimental

set-up, and comments. For the $\mathrm{CO}_{2}$ exposure facilities, watering regimes, and locations the following distinctions were made:

CO2-exposure facilities:

BRANCH - branch chambers

GC - indoor, controlled environment: growth chambers

GH - sunlit greenhouses and chambers within greenhouses

OTC - field-based open-top chambers

SPAR - high tech soil-plant-atmosphere chambers

Watering regime:

WW - well watered

W - watered

Locations :

NA - North America

CA - Central America

AU - Australia

EU - Europe

44 Arnone, J.A., III, and J.C. Gordon, 1990

GC

Light: $400 \mathrm{umol} / \mathrm{m} 2 / \mathrm{s}$

Photoperiod: $16 \mathrm{~h}$

Temperature: $26 / 20$ degC

Watering regime: Ww/drip

Nutrients: daily $1 / 4$ strength Hoagland

$\mathrm{N}$ Treatment: 0 vs $20 \mathrm{mg}$ NH4NO3-N/I

NA: North Carolina

Root nodules from inocculation with Frankia cells

112 Brown, K.R., 1991

GC

Light: $400 \mathrm{umol} / \mathrm{m} 2 / \mathrm{s}$ at canopy level Photoperiod: $18 \mathrm{~h}$

Temperature: $22 / 17$ degC

Watering regime: WW $6 \mathrm{~d} / \mathrm{wk}$ Humidity: $45 \%$

Macronutrients $6 \mathrm{~d} / \mathrm{wk} ; \mathrm{N}$ Treatment: 0.155 vs $15.5 \mathrm{mM}$ NH4NO3-N

NA: Canada: Alberta

$S E$ estimated from confidence interval

121 Bunce, J.A., 1992

$\mathrm{GH}$

Light: $27-49 \mathrm{~mol} / \mathrm{m} 2 / \mathrm{d}$

Temperature: 30-19degC

Watering regime: WW $2 e$ or $3 e$ day

fertile sandy loam+fertilizer/ 3 wks

NA: Maryland

SE and SD pers. comm. 
150 Conroy, J.P., M. Kuppers, B. Kuppers, J. Virgona, and E.W.R. Barlow, 1988

GC

Light: $450 \mathrm{umol} / \mathrm{m} 2 / \mathrm{s}$ at top of plants Photoperiod: $16 \mathrm{~h}$

Temperature: $25 / 18$ degC

watering regime: daily water

nutrients added; $P$ treatment: $P$ levels at $4.4 \mathrm{vs} 40 \mathrm{mg} / \mathrm{pot}$

$\mathrm{AU}$

P-deficient needles of $0.7-0.8 \mathrm{mgP} / \mathrm{gdrywt}$ or $1-1.5 \mathrm{mgP} / \mathrm{gdrywt}$

159 Couteaux, M.M., P. Bottner, H. Rouhier, and G. Billes, 1992

$\mathrm{GC}$

soil with micro flora, fauna and litter

EU: S France

Se assumed

168 Curtis, P.S., and J.A. Teeri, 1992

OTC

Temperature: $10 \mathrm{cal}+1.5 / 1 / 2 \mathrm{degC}$

Watering regime: Precip+w

available $\mathrm{N}: 2.7 \mathrm{ug} / \mathrm{g}$ soil

$\mathrm{NA}: \mathrm{N}$-Michigan

183 Downton, W.J.S., W.J.R. Grant, and B.R. Loveys, 1987

$\mathrm{GH}$

Light: $600-350 \mathrm{umol} / \mathrm{m} 2 / \mathrm{s}$ : top of plants-pot level Photoperiod: $10 \mathrm{~h}$

Temperature: $25 / 18$ degC

Watering regime: WW

Humidity: $60-90 \%$

$1 / 2$ strength Hoagland $2 * w k$

$\mathrm{AU}$

fruit dry wt

184 Downton, W.J.S., W.J.R. Grant, and E.K. Chacko, 1990

GC

Light: $450 \mathrm{umol} / \mathrm{m} 2 / \mathrm{s}$ initially

Photoperiod: $14-12 \mathrm{~h}$

Temperature: $30 / 22$ degC

Watering regime: WW daily Humidity: 50\%

oscomote each 3-4mo

$\mathrm{AU}$

208 El Kohen, A., J.-Y. Pontailler, and M. Mousseau, 1991

OTC

EU: France

209 El Kohen, A., H. Rouhier, and M. Mousseau, 1992

$\mathrm{GH}$

Watering regime: WW/drip

NPK Treatment: $0 \mathrm{NPK}$ vs $0.82 \mathrm{~g} \mathrm{~N}, 0.78 \mathrm{gP}, 0.4 \mathrm{gK} / \mathrm{month}$

$\mathrm{EU}$ : France

210 El Kohen, A., L. Venet, and M. Mousseau, 1993

$\mathrm{GH}$

Temperature: 1 ocal+-1.8degC

Watering regime: $\mathrm{W}$ daily

EU: France.

N(\#) Castanea from total \# plants Castanea; from Fagus from F4 
221 Ferguson, J.J., W.T. Avigne, L.H. Allen, and K.E. Koch, 1986

$\mathrm{GH}$

Light: $85 \%$ from outside

Temperature: $31 / 23$ degC

Watering regime: WW

nutrients added: NPK 20:20:20; Peter's

NA: Florida

part of gibberellin and cytokinin treatment experiment

222 Fetcher, N., C.H. Jaeger, B.R. Strain, and N. Sionit, 1988

$\mathrm{GH}$

Light: $1900 \mathrm{umol} / \mathrm{m} 2 / \mathrm{s}$ for gas exchange measurements

Temperature controlled for 30yr average

NA: N Carolina

$\mathrm{N}$ (\#) for stomatal conductance assumed same as for assimilation rate

233 Gaudillere, J.-P., and M. Mousseau, 1989

GC

Light: $250 \mathrm{umol} / \mathrm{m} 2 / \mathrm{s}$ at top of canopy Photoperiod: $16 \mathrm{~h}$

Temperature: $22 / 15$ degC

Watering regime: WW Humidity: $50 \%$

EU: France

290 Hollinger, D.Y., 1987

GC

Light: 700 umol $/ \mathrm{m} 2 / \mathrm{s}$ at top of canopy Photoperiod: $14 \mathrm{~h}$

Temperature: $20 / 10$ degC

Watering regime: WW Humidity: $70 / 90 \%$

$A U$

$\mathrm{SE}$ of mass estimated

313 Idso, S.B., B.A. Kimball, and S.G. Allen, 1991

OTC

Watering regime: WW

nutrients added

$\mathrm{NA}$ : Arizona

314 Idso, S.B., and B.A. Kimball, 1991

OTC

Watering regime: WW

nutrients added

NA: Arizona

$S D$ of mass estimated from area of $F 1$

318 Idso, S.B., and B.A. Kimball, 1993

OTC

Watering regime: WW

nutrients added

NA: Arizona

Assimilation rate and $\mathrm{N}(\#)$ estimated from $\mathrm{F} 3$

322 Idso, S.B., B.A. Kimball, and S.G. Allen, 1991

OTC

Watering regime: WW

nutrients added

NA: Arizona 
340 Kaushal, P., J.M. Guehl, and G. Aussenac, 1989

GH

Light: $80 \%$ of natural outside light $+160 \mathrm{umol} / \mathrm{m} 2 / \mathrm{s}$ at shoot level $6 \mathrm{~h} / \mathrm{d}$ Temperature: local:10-23degC

Watering regime: WW

Humidity: $80-90 \%$

EU: France

$\mathrm{SE} / \mathrm{SD}$ pers comm.

362 Koch, K.E., P. Jones, W.T. Avigne, and L.H. Allen Jr., 1986

GC

Light: $85 \%$ of incident light of outside

Temperature: $31 / 23$ degC

Watering regime: $W W$

nutrients added (Peter's)

NA: Florida

$\mathrm{SE} / \mathrm{SD}$ pers comm

468 Mousseau, M., 1993

OTC

Temperature: $35-10 / 22-5$ degC

Watering regime: WW

nutrients added

EU: France

$N(\#)$ of mass assumed as in $T 1$ pap 471

470. Mousseau, M., and H.Z. Enoch, 1989

OTC

Temperature: local+max4degC

watering regime: WW/drip

nutrients added/yr

EU: France

502 Norby, R.J., C.A. Gunderson, S.D. Wullschleger, E.G. O'Neill, and M.K. McCracken, 1992

OTC

soils potentially NP deficient

NA: $35.9 \mathrm{degN} 84.4 \mathrm{deg} W$

note on drought and nutrient deficiency

503 Norby, R.J., E.G. O'Neill, W.G. Hood, and R.J. Luxmoore, 1987

GC

Light: $540 \mathrm{umol} / \mathrm{m} 2 / \mathrm{s}$

Photoperiod: $14 \mathrm{~h}$

Temperature: $25 / 7 \mathrm{degC}$

watering regime: $W$

soils potentially NP deficient

Humidity: 65\%

NA: Tennessee

potential soil nutrient deficient

504 Norby, R.J., E.G. O'Neill, and R.J. Luxmoore, 1986

GC

Iight: 660 umol/m2/s at top of canopy Photoperiod: 14h

Temperature: $25 / 15 \mathrm{degC}$

watering regime: WW/arip

Humidity: $65 \%$

soils potentially NP deficient

NA: Tennessee

SE/SD for F1,T1,T2: e-mail; soil potentially nutrient deficient 
$\mathrm{GH}$

Light: $580 \mathrm{umol} / \mathrm{m} 2 / \mathrm{s}$

Photoperiod: $14 \mathrm{~h}$

Temperature: $26 / 10 \mathrm{degC}$

Watering regime: WW

Humidity: $65 / 95 \%$

NPK treatment: $\quad 0$ NPK vs $5,1.5,1.9 \mathrm{mg} \mathrm{N}, \mathrm{P}, \mathrm{K} /$ pot/wk

NA: Tennessee

SE/SD: e-mail

506 Norby, R.J., and E.G. O'Neill,1991

GC

Light: $600 \mathrm{umol} / \mathrm{m} 2 / \mathrm{s}$

Photoperiod: $14 \mathrm{~h}$

Temperature: $26 / 12 \mathrm{deg}$

Watering regime: $W W$

Humidity: $70 / 90 \%$

nutrients: $20.0 \cdot 4 \cdot 5,16.5 \mathrm{mg} \mathrm{NPK}+/ \mathrm{wk}$; later $2^{*} \mathrm{wk}$

NA: Tennessee

$N(\#)$ from author

510 O'NeilI, E.G., R.J. Luxmoore, and R.J. Norby, 1987

GC

Light: 450 umol $/ \mathrm{m} 2 / \mathrm{s}$

Photoperiod: $14 \mathrm{~h}$

Temperature: $26 / 10$ degC

Watering regime: WW

no nutrients added

NA: Tennessee

521 Overdieck, D., 1990

GC

Watering regime: $W$ as precip

soils of average fertility

$\mathrm{EU}$ : Germany: 52degN 8degE

550 Pettersson, R., and A.J.S. McDonald, 1992

GC

Light: $600 \mathrm{umol} / \mathrm{m} 2 / \mathrm{s}$

Photoperiod: $18 \mathrm{~h}$

Temperature: $20 \mathrm{deg} \mathrm{C}$

hydroponics

nutrient solution

EU: Sweden

$N$ (\#) 2-5: pers comm for gas exchange; as T1 for other measures

553 Polle, A., T. Pfirrmann, S. Chakrabarti, and H. Rennenberg, 1993

GC

controlled as for local environment

watering regime: WW: drip acidic mists

Ozone Treatment: 0.02 vs $0.08 \mathrm{~cm} 3 / \mathrm{m} 3: 24 \mathrm{hrs} / \mathrm{d}$ like higher elevations

EU: Germany:Bavaria

582 Reekie, E.G., and F.A. Bazzaz, 1989

$\mathrm{GH}$

Light: local with 1000-1200 umol/m2/s max levels

Temperature: local 30/27degC

Watering regime: WW

monthly Peter's fertilization $(20: 20: 20)$

Plant competition of tropical plants

NA: Massachusetts 
GH

Light: 900 umol $/ \mathrm{m} 2 / \mathrm{s}$ clear days

Temperature: $28 / 20 \mathrm{degC}$

watering regime: Ww

nutrients added each 2 weeks

Humidity: $73 \%$

NA: Massachusetts

644 Sharkey, T.D., F. Loreto, and C.F. Delwiche, 1991

$\mathrm{GH}$

Light: $300-500 \mathrm{umol} / \mathrm{m} 2 / \mathrm{s}$ (gas measurements at $900 \mathrm{umol} / \mathrm{m} 2 / \mathrm{s}$ )

Photoperiod: $15 \mathrm{~h}$

Temperature: 25/20degC Humidity: $70 \% / 85 \%$

NA: Wisconsin

Partly a shading and isoprene emission experiment

655 Sionit, N., B.R. Strain, H. Hellmers, G.H. Riechers, and C.H. Jaeger, 1985

$\mathrm{GH}$

Temperature: night temp controlled

watering regime: WW/drip

nutrients (Hoagland 1/15 strength daily

NA: North Carolina

666 Stewart, J.D., and J. Hoddinott, 1993

$\mathrm{GH}$

Light: 600 umol $/ \mathrm{m} 2 / \mathrm{s}$ as maximum

Photoperiod: $18 \mathrm{~h}$

Temperature: 15-32degC (local)

Watering regime: WW: 2 *wk

nutrients $1 / w k$

UVB Treatment: $0.005-0.03$ vs $0.25-0.90 \mathrm{~W} / \mathrm{m} 2$

NA: Canada: Alberta

676 Surano, K.A., P.F. Daley, J.L.J. Houpis, J.H. Shinn, J.A. Helms, R.J. Palassou, and M.P. Costella, 1986

OTC

Iight: 80-90\% from outside

Temperature: 10cal+upto5degC

Watering regime: WW:3*wk+ Humidity: down to $10 \%$

nutrients added/month: NPK $+2.2,1.8,1.3 \mathrm{~g} / \mathrm{pot} / \mathrm{month}$

NA: California

682 Thomas, R.B., D.D. Richter, H. Ye, P.R. Heine, and B.R. Strain,

GC

Light: $1000 \mathrm{umol} / \mathrm{m} 2 / \mathrm{s}$

Temperature: $29 / 23$ degC

watering regime: $W W$

Photoperiod: $14 \mathrm{~h}$

nutrients added daily with/without $N$

Humidity: $70 \%$

$\mathrm{N}$ Treatment: 0 vs $7.0 \mathrm{mM}$ NH4NO3-N

NA: South Carolina

Seeds inocculated with Rhizobium

745 Wullschleger, S.D., R.J. Norby, and D.L. Hendrix, 1992

OTC

gas exchange measures at $1300 \mathrm{umol} / \mathrm{m} 2 / \mathrm{s}$

NA: $35.9 \mathrm{degN} 84.4 \mathrm{degW}$

Precip $169 \mathrm{~cm}$ at study site compared to $139 \mathrm{~cm}$ as $30 \mathrm{yr}$ average 
746 Wullschleger, S.D., R.J. Norby, and C.A. Gunderson, 1992

OTC

NA: $35.9 \mathrm{degN} 84.4 \mathrm{degW}$

747 Wullschleger, S.D., and R.J. Norby, 1992

OTC

NA: $35.9 \mathrm{degN} 84.4 \mathrm{deg} W$

756 Ziska, I.H., K.P. Hogan, A.P. Smith, and B.G. Drake, 1991

OTC

Light: $740 \mathrm{umol} / \mathrm{m} 2 / \mathrm{s}$ average; $1200 \mathrm{umol} / \mathrm{m} 2 / \mathrm{s} \max$ Photoperiod: 10h

Temperature: $36.5 / 21.2 \mathrm{degC}$

Watering regime: WW 2 day

nutrients added (Osmocote)

Humidity: $60 \% / 85 \%$

$\mathrm{CA}: 83.9 \mathrm{degN} 9.2 \mathrm{degW}$

Values differ slightly from Table: pers comm

2002 Gorissen, A., P.J. Kuikman, and H. Van De Beek, 1995

GC

Light: $400 \mathrm{umol} / \mathrm{m} 2 / \mathrm{s}$

Photoperiod: $16 \mathrm{~h}$

Temperature: $18 / 14 \mathrm{degC}$

Watering regime: $\mathrm{W}$

Humidity: $70-80 \%$

$\mathrm{EU}: 52.2 \mathrm{degN} 5.8 \mathrm{degE}$

2003 Mortensen, I.M., 1995

GC

Light: $18 \mathrm{~mol} / \mathrm{m} 2 /$ day for temp treatment

Light: $22 \mathrm{~mol} / \mathrm{m} 2 /$ day for Ozone treatment Photoperiod: 24h

Temperature: $17.3 \mathrm{deg}=\mathrm{control}$

Watering regime: Ww

nutrients added

2 Treatments: Ozone: 7 vs $62 \mathrm{nmol} / \mathrm{mol}$ for $8 \mathrm{hrs}$

$\mathrm{EU}: 60.8 \mathrm{degN} 11.5 \mathrm{degE}$ Temperature: 15.3 vs 20 degC

2004 Wullschleger, S.D., R.J. Norby, and P.J. Hanson, 1995

OTC

NA: $35.9 \mathrm{degN} 84.4 \mathrm{deg} W$

Pisolithus tinctorius mycorrhizal inoculum; stem respiration

2005 Teskey, R.O., 1995

BRANCH

Light: $1200 \mathrm{umol} / \mathrm{m} 2 / \mathrm{s}$ for gas exchange measurements

Watering regime: irrigated

NA: Georgia: $33.9 \mathrm{degN} 82.3 \mathrm{degW}$

2026 Callaway, R.M., E.H. Delucia, E.M. Thomas, and W.H. Schlesinger, 1994 GC

Light: $1000 \mathrm{umol} / \mathrm{m} 2 / \mathrm{s}$

Photoperiod: $12 \mathrm{~h}$

Temperature Treatment: $25 / 10$ degC vs $30 / 25$ degC

watering regime: WW

Humidity: 45\%i during day

nutrients $1 / 2$ strength Hoagland

NA: Nevada

2027 Pettersson, R., A.J.S. McDonald, and I. Stadenberg, 1993

GC 
Light: $500 \mathrm{umol} / \mathrm{m} 2 / \mathrm{s}$ Temperature: $20 \mathrm{deg} C$ Hydroponic nutrient solution

$\mathrm{N}$ Treatment: 0.07 vs $0.15 \mathrm{molN} / \mathrm{molN} / \mathrm{d}$

$\mathrm{EU}$ : Sweden

2028 Lavola, A., and R. Julkunen-Tiitto, 1994

$\mathrm{GH}$

Light: local -- 1137-175 umol/m2/s

Temperature: $22 / 15 \mathrm{degC}$

NKP Treatment: 0 vs $500 \mathrm{~kg} / \mathrm{ha}$

$\mathrm{EU}$ : Finland

2032 Tschaplinski, T.J., R.J. Norby, and S.D. Wullschleger, 1993

GC

Light: 720 umol/m2/s

Temperature: $26 / 16$ degC

H20 Treatment: weekly vs biweekly watering Humidity: 85-90\% fertilized/month (Peter's NPK 20:20:20)

NA: Tennessee

2035 Gunderson, C.A.,.R.J. Norby, and S.D. Wullschleger, 1993 OTC

Light: 1100-2300 umol/m2/s for gas exchange measurements

Temperature: local

Watering regime: precip

NA: $35.9 \operatorname{degN} 84.4 \mathrm{degW}$

2036 Grulke, N.E., J.I. Hom, and S.W. Roberts, 1993

GC

Light: $713 \mathrm{umol} / \mathrm{m} 2 / \mathrm{s}$ at canopy height Photoperiod: 12hr later 14h Temperature: $25 / 19$ degC

Watering regime: WW

Humidity: $46-57 \% / 81 \%$

fertilized weekly

NA: California

2037 Bazzaz, F.A., S.L. Miao, and P.M. Wayne, 1993

\section{$\mathrm{GH}$}

Light: $37 \%$ and $75 \%$ of full sun

Temperature: $30 / 23 \mathrm{degC}$

2 Treatments: Light: $37 \%$ and $75 \%$ of full sun

NA: Massachusetts

Fertilizer: 0.18 and $1.8 \mathrm{~g}$ Oscomote

2038 Roth, S.K., and R.L. Lindroth, 1994

GC

Light: $501 \mathrm{umol} / \mathrm{m} 2 / \mathrm{s}$

Temperature: $25 / 20$ degc

Watering regime: WW/drip

Photoperiod: $15 \mathrm{~h}$

fertilized $1 / 2$ strength Hoagland 2 *per day

NA: Wisconsin

2039 Curtis, P.S., C.S. Vogel, K.S. Pregitzer, D.R. Zak, and J.A. Teeri, 1995 OTC

Light: gas exchange measures at $1800 \mathrm{unol} / \mathrm{m} 2 / \mathrm{s}$

Temperature: local 
Watering regime: WW

Soil Treatment: 45 vs $346 \mathrm{ug} N / \mathrm{g} / \mathrm{d} \mathrm{N}$ mineralization in soils

64 vs $110 \mathrm{mg}$ extractable $\mathrm{PO} / \mathrm{kg}$ soil

NA: N-Michigan

2041 Garcia, R.L., S.B. Idso, G.W. Wall, and B.A. Kimball, 1994

OTC

Watering regime: WW

fertilized

NA: Arizona

2042 Sullivan, J.H., and A.H. Teramura, 1994

$\mathrm{GH}$

Light: $\sim 80-85 \%$ of outdoors

Temperature: $27 / 23$ degC

Watering regime: Ww/daily

fertilized $1 / 2$ strength Hoagland

UVB Treatment: $8 \mathrm{hrs}$ daily 8.8 vs $13.8 \mathrm{~kJ} / \mathrm{m} 2$

NA: Maryland

$S E$ for $T 1 S E$ for $F 1$ (e-mail)

2043 Cipollini, M.I., B.G. Drake, and D. Whigham, 1993

OTC

Light: 10-100-occasionally $1000 \mathrm{umol} / \mathrm{m} 2 / \mathrm{min}$

NA: Maryland

2044 Tissue, D.T., R.B. Thomas, and B.R. Strain, 1993

OTC

Watering regime: precip

$1 / 2$ strength Hoagland $2{ }^{*}$ week

2 Treatments: High $\mathrm{NP}: 7 \mathrm{~mol} / \mathrm{m} 2 \mathrm{NH} 4 \mathrm{NO} 3+1 \mathrm{~mol} / \mathrm{m} 3 \mathrm{PO} 4$; low $\mathrm{P}:$ same $\mathrm{N}+0.2 \mathrm{~mol} / \mathrm{m} 3 \mathrm{P}$;

NA: North Carolina

lowN : $1 \mathrm{~mol} / \mathrm{m} 3 \mathrm{NH} 4 \mathrm{NO} 3+1 \mathrm{mo} 1 / \mathrm{m} 3 \mathrm{PO} 4$

$\mathrm{N}(\#)$ in $\mathrm{T} 1$ does not match text

2045 Johnsen, K.H., 1993

GC

Light: $450 \mathrm{umol} / \mathrm{m} 2 / \mathrm{s}$ at bench height Photoperiod: $19 \mathrm{~h}$ Temperature: $20 / 15$ degC

watering treatment

treatment within $1 / 3$ strength Ingestad

Humidity: $70 / 90 \%$

2 Treatments:

WW vs drought cycles (fertilized with $8 \mathrm{~mL} 300 \mathrm{ppmN}$ : Ingestad);

Fertilization: $6 \mathrm{~mL} / \mathrm{wk}$ then $12 \mathrm{~mL}$ after 71 days vs $12 \mathrm{~mL}$,

$18 \mathrm{~mL}, 24 \mathrm{~mL}, 32 \mathrm{~mL}$ after day $1,42,71$ and 104

NA: Canada: Ontario

2046 Reid, C.D., and B.R. Strain, 1994

GC

Light: $65 \mathrm{umol} / \mathrm{m} 2 / \mathrm{s}$

Photoperiod: $12 \mathrm{~h}$

Temperature: 19/15degC

watering regime: WW daily

1/4 strength Hoagland

NA: North Carolina

2047 Eamus, D., C.A. Berryman, and G.A. Duff, 1993 
OTC

Light: ambient local

Temperature: local-up to $1.5 \mathrm{deg} C$

$\mathrm{AU}$

2048 Yakimchuk, R., and J. Foddinott, 1994

GC

Light: $150 \mathrm{umol} / \mathrm{m} 2 / \mathrm{s}+2 \mathrm{hrs} 40 \mathrm{umol} / \mathrm{m} 2 / \mathrm{s}$ Photoperiod: $18 \mathrm{~h}$

Temperature: $20 / 18 \mathrm{degc}$

Watering regime: WW Humidity: 65\%

fertilized weekly

ozone treatment: $1.1 \mathrm{uW} / \mathrm{cm} 2$ vs $150 \mathrm{uW} / \mathrm{cm} 28 \mathrm{hrs} /$ day

NA: Canada: Alberta

potsize: pers. com.

2065 Liu, S., and R.O. Teskey, 1995

BRANCH

Light: gas exchange at $1000-2000 \mathrm{umol} / \mathrm{m} 2 / \mathrm{s}$

Temperature: $16.5 \mathrm{degC}$

Watering regime: $w+$ precip

low to medium soil fertility

NA: 33.9 degN 83.3 degW

mature trees, low fertility site

2068 Wang, K., S. Kellomaki, and K. Laitinen, 1995

OTC

Temperature treatment: ambient vs hot $=a m b+2 d e g c$ in summer, $a m b+5-20 d e g c$ Watering regime: $W+$ precip

sandy soil

EU: 62.8 degN $30.9 \mathrm{degE}$

chamber around coniferous saplings; elevated $\mathrm{CO} 2$ only during daytime

2069 Marek, M.V., J. Kalina, and M. Matouskova, 1995

OTC

native Coniferous

$\mathrm{EU}: 49.5 \mathrm{degN} 18.5 \mathrm{degW}$

native coniferous; elevated $\mathrm{CO} 2$ level is saturating level

2070 Eamus, D., G.A. Duff, and C.A. Berryman, 1995

SPAR

Light: $68 \%$ of full

Temperature: local minus upto $3 \mathrm{degC}$

watering regime: WW/drip

Osmocote in soils

$\mathrm{AU}$

2071 Eamus, D., C.A. Berryman, and G.A. Duff, 1995

SPAR

Light: $66 \%$ of full

Temperature: local minus upto $3 \mathrm{deg} C$

Watering regime: WW 2 *day

fertilized each 2 weeks

$\mathrm{AU}$

2109 Johnson, D., D. Geisinger, R. Walker, J. Newman, J. Vose, K. Elliot, and T. Ball, 1994

OTC 
Watering regime: WW

$\mathrm{N}$ treatment: 0 vs $20 \mathrm{~g} / \mathrm{m} 2 / \mathrm{yr}$ ammonium sulfate

NA: California

SE vs SD estimates F5; chamber description in Ball et al (1992)

2110 Pregitzer, K.S., D.R. Zak, P.S. Curtis, M.E. Kubiske, J.A. Teeri, and C.S. Vogel, 1995

OTC

Watering regime: WW

Soil treatment: 45 vs $348 \mathrm{ug} \mathrm{N} / \mathrm{g} / \mathrm{d} \mathrm{N}$ mineralization in soils;

NA: N-Michigan

64 vs $110 \mathrm{mg}$ extractable $P 04 / \mathrm{kg}$ soil

2117 Mortensen, L.M., 1994

GC

Light treatment: $15 \mathrm{~mol} / \mathrm{m} 2 / \mathrm{d}$ then $22 \mathrm{~mol} / \mathrm{m} 2 / \mathrm{d}$ for birch,

$21 \mathrm{~mol} / \mathrm{m} 2 / \mathrm{d}$ for spruce

Photoperiod: $24 \mathrm{~h}$

Temperature Treatment: 15.3 vs 20.0 degC

watering regime: WW 600 vs $1000 \mathrm{~Pa}$ as wvpd at 15.3 vs $20 \mathrm{degC}$

fertilized, see Mortensen, 1994

EU: Norway

2120 Laboratorium Voor Plantecologie

GC

Light: $270 \mathrm{umol} / \mathrm{m} 2 / \mathrm{s}$

Temperature: $22 / 17.5$ degC

Watering regime: WW/drip

fertilized at optimal levels

1992

EU: Belgium

2121 Kubiske, M.E., and K.S. Pregitzer, 1994

OTC

Light Treatment: low and high; understory imitation

NA: N-Michigan

2122 Vogel, C.S., and P.S. Curtis, 1995

OTC

Temperature: 1ocal+2.6degC

fertilized with $4.5 \mathrm{~g} / \mathrm{m} 2 \mathrm{~N}$

NA: $45.6 \mathrm{degN} 84.7 \mathrm{deg} W$

nodule inoculations

2123 Jarvis, P.G., H.S.J. Lee, and C.V.M. Barton, 1994

OTC

Light and temperature not reported for growth

$\mathrm{EU}$ : Scotland

$\mathrm{N}(\#)$ pers comm for $\mathrm{T} 2$

2129 Curtis, P.S., D.R. Zak, K.S. Pregitzer, and J.A. Teeri, 1994

OTC

Temperature: 1 ocal $+3 \mathrm{degC}$

watering regime: precip+w

All rootboxes received $4.5 \mathrm{~g} / \mathrm{m} 2 \mathrm{~N}$; similar to natural dry oak forest

NA: N-Michigan

2131 Norby, R.J., Wullschleger, and C.A. Gunderson, 1996

\section{C-11}


OTC

NA: Tennessee

Sample size and SD from pers comm.

2152 Williams, R.S., D.E. Lincolm, and R.B. Thomas, 1994

OTC

Watering regime: precip+W

modified Hoagland 7mmol $\mathrm{NH} 4 \mathrm{NO} 3+1 \mathrm{mmolPO} 4 / \mathrm{wk}$

NA: North Carolina

2165 Lewis, J.D., R.B. Thomas, and B.R. Strain, 1994

$\mathrm{GH}$

Temperature: $28 / 17-28 / 22$ degC

Watering regime: WW

1/2 strength Hoagland/wk; P Treatment: $0.083 \mathrm{mM}$ KH2PO4 vs $0.5 \mathrm{mM} \mathrm{KH2PO4:}$

NA: North Carolina

P stress

inocculation Pisolithus tinctorius vs not

2186 Bassow, S.L., K.D.M. McConnaughay, and F.A. Bazzaz, 1994

$\mathrm{GH}$

Light: natural+supplement when light $<500 u m o l / \mathrm{m} 2 / \mathrm{s}$ i

Photoperiod local: 6-19h

Temperature: $28 / 22$ degC

Fertilizer Treatment: 0.12 vs $1.2 \mathrm{~g}$ Osmocote $>\mathrm{N}$ input of

40 vs $400 \mathrm{~kg} \mathrm{~N} / \mathrm{ha} / \mathrm{Yr} ; 3 \mathrm{mo}$ after initial osmocote weekly $200 \mathrm{ml}$ Peter's solution $(20: 20: 20)$ at

NA: Massachusetts

$0.042 \mathrm{v}$ s $0.42 \mathrm{~g} / 1 / \mathrm{wk}$

N(\#) FI: pers. comm

2217 Berryman, C.A., D. Eamus, and G.A. Duff, 1993

OTC

Light: $65 \%$ of full

Temperature: $29.7 \mathrm{degC}$

Watering regime: WW: $3 *$ day

nutrients added; also $5 \mathrm{~g}$ low $\mathrm{P}$ Osmocote

$\mathrm{AU}$

2223 Bazzaz, F.A., and S.L. Miao, 1993

$\mathrm{GH}$

Light treatment: full gap light vs $37 \%$ thereof

Temperature: $27 / 20>30 / 23$ degC

Watering regime: WW

nutrient treatment: $N$ equivalents of $40 \mathrm{vs} 400 \mathrm{~kg} \mathrm{~N} / \mathrm{ha} / \mathrm{Yr}$ i.e.

NA: Massachusetts

0.18 vs $1.8 \mathrm{~g}$ Osmocote/pot

2224 Lindroth, R.L., K.K. Kinney, and C.L. Platz, 1993

$\mathrm{GH}$

Light: $490 \mathrm{~mol} / \mathrm{m} 2 / \mathrm{s} 70 \mathrm{~cm}$ above pots Photoperiod: $15 \mathrm{~h}$

Temperature: $25 / 20 \mathrm{degC}$

watering regime: WW/drip

Humidity: $70 / 80 \%$

1/2 strength Hoagland

NA: Wisconsin

native mycorrhiza in soil 


\section{APPENDIX D: REPRINT OF PERTINENT LITERATURE}

Curtis, P. S., and X. Wang. 1998. A meta-analysis of elevated $\mathrm{CO}_{2}$ effects on woody plant mass, form, and physiology. Oecologia 113:299-313.

(c) Springer-Verlag (Heidelberg, Germany) and reprinted with kind permission from the publisher. 

Peter S. Curtis $\cdot$ Xianzhong Wang

\section{A meta-analysis of elevated $\mathrm{CO}_{2}$ effects on woody plant mass, form, and physiology}

Received: 16 May 1997 / Accepted: 9 September 1997

\begin{abstract}
Quantitative integration of the literature on the effect of elevated $\mathrm{CO}_{2}$ on woody plants is important to aid our understanding of forest health in coming decades and to better predict terrestrial feedbacks on the global carbon cycle. We used meta-analytic methods to summarize and interpret more than 500 reports of effects of elevated $\mathrm{CO}_{2}$ on woody plant biomass accumulation and partitioning, gas exchange, and leaf nitrogen and starch content. The $\mathrm{CO}_{2}$ effect size metric we used was the log-transformed ratio of elevated compared to ambient response means weighted by the inverse of the variance of the $\log$ ratio. Variation in effect size among studies was partitioned according to the presence of interacting stress factors, length of $\mathrm{CO}_{2}$ exposure, functional group status, pot size, and type of $\mathrm{CO}_{2}$ exposure facility. Both total biomass $\left(W_{\mathrm{T}}\right)$ and net $\mathrm{CO}_{2}$ assimilation $(A)$ increased significantly at about twice ambient $\mathrm{CO}_{2}$, regardless of growth conditions. Low soil nutrient availability reduced the $\mathrm{CO}_{2}$ stimulation of $W_{\mathrm{T}}$ by half, from $+31 \%$ under optimal conditions to $+16 \%$, while low light increased the response to $+52 \%$. We found no significant shifts in biomass allocation under high $\mathrm{CO}_{2}$. Interacting stress factors had no effect on the magnitude of responses of $A$ to $\mathrm{CO}_{2}$, although plants grown in growth chambers had significantly lower responses $(+19 \%)$ than those grown in greenhouses or in open-top chambers $(+54 \%)$. We found no consistent evidence for photosynthetic acclimation to $\mathrm{CO}_{2}$ enrichment except in trees grown in pots $<0.51(-36 \%)$ and no significant $\mathrm{CO}_{2}$ effect on stomatal conductance. Both leaf dark respiration and leaf nitrogen were significantly reduced under elevated $\mathrm{CO}_{2}(-18 \%$ and $-16 \%$ respectively, data
\end{abstract}

P.S. Curtis $(\varangle)^{\prime} \cdot X$. Wang

Dept. of Plant Biology, The Ohio State University,

1735 Neil Ave., Columbus, OH 43210, USA

Present address:

'Dept. of Plant Biology, The Ohio State University,

1735 Neil Ave., Columbus, OH 43210-1293, USA

e-mail: curtis.7@osu.edu; Fax: 614-292-6345 expressed on a leaf mass basis), while leaf starch content increased significantly except in low nutrient grown gymnosperms. Our results provide robust, statistically defensible estimates of elevated $\mathrm{CO}_{2}$ effect sizes against which new results may be compared or for use in forest and climate model parameterization.

Key words Elevated $\mathrm{CO}_{2} \cdot$ Meta-analysis - Woody plants

\section{Introduction}

Forested ecosystems cover approximately $35 \%$ of the world's land surface and may accounted for as much as $70 \%$ of terrestrial net primary productivity (Meyer and Turner 1992; Mellilo et al. 1993). Their future prospects are of concern to many millions of people who rely on forests directly or indirectly for food, fuel, building material, and the myriad of ecological goods and services they provide. Increasing atmospheric $\mathrm{CO}_{2}$ has the potential to fundamentally alter forest ecosystem functioning through effects on tree growth, resource use, and species interactions (Eamus and Jarvis 1989). Because of their prominent role in the global carbon cycle, forests may in turn affect the rate of atmospheric $\mathrm{CO}_{2}$ increase (Walker and Kasting 1992). The extent and manner with which trees respond to changes in $\mathrm{CO}_{2}$ concentration has thus been of interest to the forest products industry, natural resource managers, ecologists, and atmospheric scientists.

Empirical research on $\mathrm{CO}_{2}$ effects in forests has proceeded along numerous lines of inquiry, but the great majority of studies share certain common features. In these experiments, the $\mathrm{CO}_{2}$ treatments to which plants are exposed are typically ambient $(c .35 \mathrm{~Pa})$ and twice ambient (c. $70 \mathrm{~Pa}$ ) $\mathrm{CO}_{2}$ partial pressure with additional levels occasionally included. Atmospheric $\mathrm{CO}_{2}$ levels are expected to reach $70 \mathrm{~Pa}$ in the next $100-150$ years (Houghton et al. 1990). Elevated $\mathrm{CO}_{2}$ treatments are imposed as a single step change from ambient $\mathrm{CO}_{2}$ levels 
by adding $100 \% \mathrm{CO}_{2}$ to the input air supply of controlled environment growth chambers (GC), greenhouses $(\mathrm{GH})$ or field-based open-top chambers (OTC) (Schulze and Mooney 1994). First-year seedlings or young plants propagated from cuttings are used most often as experimental material, although occasionally mature trees or branches of trees are studied (e.g., Cipollini et al. 1993; Liu and Teskey 1995). Of considerable interest to workers studying elevated $\mathrm{CO}_{2}$ has been the effect of interacting environmental variables on the magnitude of $\mathrm{CO}_{2}$ responses by trees. Consequently, experiments are often set up as two-way factorial designs, with $\mathrm{CO}_{2}$ crossed with another factor such as nitrogen availability or ozone level. While the specific objectives of individual researchers and the duration of their experiments vary widely, basic measures of plant growth (e.g., biomass, leaf area), physiological performance (e.g., gas exchange), and tissue composition (e.g., leaf $\mathrm{N}$ content) are often reported.

These common design and measurement characteristics are an advantage when attempting to integrate results across studies. Nonetheless (and not surprisingly), there is a substantial degree of variation in the magnitude of reported $\mathrm{CO}_{2}$ effects on trees, ranging from significant inhibition of growth by elevated $\mathrm{CO}_{2}$, to enhancements in excess of $500 \%$ relative to ambient grown plants (McGuire et al. 1995). An important goal in reviews of this work is to partition this variation into that which can be explained by treatment effects common to groups of studies and that which is due to sampling error or other idiosyncratic effects specific to individual studies. For example, in a set of 102 measurements of total tree biomass, growth at elevated $\mathrm{CO}_{2}$ resulted in an average weight gain of $29 \%$ across a range of from $-31 \%$ (inhibition) to $+284 \%$ (stimulation) (Fig. 1). One obvious way to partition this data set is by whether or not another factor that could affect the magnitude of the $\mathrm{CO}_{2}$ response was included in the experimental design of each study. While this narrows the range of responses within groups, there remains both broad overlap in responses between groups and substantial variation within groups (Fig. 1). Further partitioning of groups might be according to factors not considered explicit treatments by the primary researchers but that could help account for this remaining variation, such as length of study, size of pots in which plants were grown, or "quality" of the science being reported (however that might be defined). One objective of such an exercise is to identify groups of studies whose combined results can lead to meaningful generalizations regarding the response parameter under study, in this case percent change in whole plant biomass.

In a traditional narrative literature review, results from those individual studies that are judged by the reviewer to be representative or otherwise noteworthy are summarized qualitatively, serving as the basis for generalization, extrapolation, or other objectives of the reviewer. Although the narrative approach has been, and will no doubt continue to be, of fundamental importance

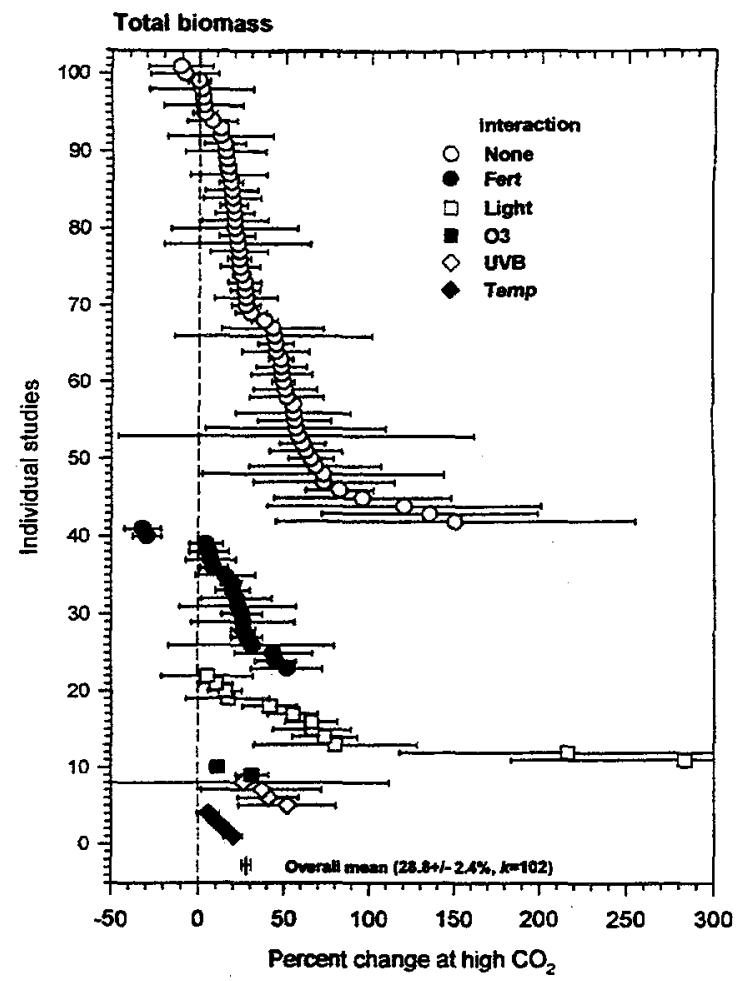

Fig. 1 Percent change in total (above + belowground) biomass in woody plants grown under elevated compared to ambient $\mathrm{CO}_{2}$ as reported in 102 different experiments. Results are grouped according to whether plants were exposed either to no stress (None), low nutrient availability (Fert), low light levels ( $L$ ight $)$, high ozone (O3), high UVB $(U V B)$ or low or high temperature (Temp) in addition to the $\mathrm{CO}_{2}$ treatment. Mean $\pm 1 \mathrm{SE}$ calculated from the log-transformed response ratio

in synthesizing many types of scientific research, it is inadequate for the quantitative integration of large numbers of research reports (Cooper and Rosenthal 1980). Review of the literature on elevated $\mathrm{CO}_{2}$ has for some time included both narrative reviews and quantitative summaries, with the latter in some cases involving results from hundreds of published reports (e.g., Cure 1985; Idso and Idso 1994). Quantitative summaries have been important in model parameterization and in establishing benchmarks against which other work can be compared (e.g., Kimball 1983). Unfortunately, their utility has been hampered by ad hoc sampling and analysis methods that do not allow statistically robust hypothesis testing or comparison among groups.

Statistical methods have been developed for the quantitative integration of research results from independent experiments (Hedges and Olkin 1985; Cooper and Hedges 1994). Such formal integration, or metaanalysis, of data has been conducted extensively in the social and medical sciences (Mann 1994) and has recently been extended to ecological studies (Arnqvist and Wooster 1995). The advantage of meta-analysis over quantitative methods previously used in reviews of work on elevated $\mathrm{CO}_{2}$ is the ability to place confidence limits 
around effect size estimates, to discriminate statistically among subsets of the data, and to compare critically the variance within and among studies. More generally, it requires of reviewers the same rigor in sampling and analysis as is required of primary researchers.

Here, we used meta-analytic methods to summarize and interpret 508 reports of $\mathrm{CO}_{2}$ effects on tree physiology and growth taken from 79 separate publications and 59 species (Appendices 1 and 2). This paper extends the work of Curtis (1996) and introduces a new metaanalytic metric, the weighted log ratio. Our review has two primary objectives: (1) to provide estimates of the magnitude and significance of elevated $\mathrm{CO}_{2}$ effects on tree biomass accumulation and partitioning, gas exchange, and leaf nitrogen and starch content; and (2) to determine how experimental design factors or taxonomic affinity affects the magnitude of these $\mathrm{CO}_{2}$ responses. We do not address the issue of how, or under what conditions, these results may be scaled up to predict the behavior of entire forests or biomes. As with any effort to integrate and interpret scientific information, considerable caution is advised when extrapolating beyond the range of ones data.

\section{Methods}

\section{Database development}

Bibliographic resources used in developing the meta-database were Strain and Cure (1986, 1994), and the Current Advances in Plant Science and Current Contents citation indices. Our literature survey was intended to be comprehensive, with all published studies conducted with woody species available through December 1995 included. We extracted information on 36 response variables, ten of which will be reported on here. Those are: total above- + belowground biomass $\left(W_{\mathrm{T}}\right)$, below-ground biomass $\left(W_{\mathrm{B}}\right)$, stem biomass $\left(W_{\mathrm{S}}\right)$, total leaf biomass $\left(W_{\mathrm{L}}\right)$, light saturated net $\mathrm{CO}_{2}$ assimilation $(A)$, photosynthetic acclimation or downregulation $\left(A_{\text {acel }}\right)$, stomatal conductance $\left(g_{\mathrm{s}}\right)$, leaf dark respiration $\left(R_{d}\right.$, expressed on a leaf mass basis), leaf starch concentration ( $\mathrm{St}_{\mathrm{L}}$, expressed on a mass basis), and leaf nitrogen concentration ( $N_{\mathrm{L}}$, expressed on a mass basis).

For results from any given study to be included in the metadatabase there was a general requirement that response means
$\left(\bar{X}_{e}, \bar{X}_{a}\right)$, standard deviations $\left(S_{e}, S_{a}\right)$ (or standard errors), and sample sizes $\left(n_{e}, n_{a}\right)$ of elevated and ambient $\mathrm{CO}_{2}$ grown plants respectively be reported as numerical or graphical data in the manuscript, or be available by personal communication. This requirement was necessary for the weighting of response ratios according to precision of the primary results. Given the unevenness with which these basic statistical measures were reported, this requirement resulted in many published observations being excluded from consideration. An additional requirement was that ambient treatments be below $40 \mathrm{~Pa} \mathrm{CO}$ and elevated treatments be between 60 and $80 \mathrm{~Pa} \mathrm{CO}_{2}$. Most meta-analytic methods require that individual observations be statistically independent so only one measurement point per treatment per study was used. In most cases these were data obtained following the longest period of $\mathrm{CO}_{2}$ exposure reported in that study. "Treatment" included species identity as well as crossed experimental factors interacting with $\mathrm{CO}_{2}$ such as ozone level or soil nutrient availability. Thus, a study examining a number of species in a multi-factorial design could contribute several observations for each response variable measured (e.g., Bazzaz and Miao 1993; Kubiske and Pregitzer 1996)

We were specifically interested in how different categorical variables influenced the magnitude of elevated $\mathrm{CO}_{2}$ responses. The five categorical variables whose effects we discuss here are, environmental stress factors (Stress), plant functional group (Func Grp), length of $\mathrm{CO}_{2}$ exposure (Time), pot size (Pot), and type of exposure facility (Method) (Table 1). We required information on each of these variables for a study to be included in the database. For purposes of meta-analysis we established discrete levels for each variable and coded each observation accordingly. In most cases coding decisions were unambiguous but occasionally subjective interpretations were required to place a particular experimental design or treatment within one of these categorical levels. For example, field studies having "native soil" were considered unstressed unless some stress factor had been clearly identified by the author. Low $N$ studies with $N_{2}$-fixing plants and low $\mathbf{P}$ studies with mycorrhizal plants were also considered unstressed. The basis for coding decisions was described in more detail by Curtis (1996). The Stress factor associated with each study is also listed in Appendix 2.

\section{Meta-analysis of response ratios}

Meta-analytic studies depend on some estimate of treatment effect size, commonly the magnitude of an experimental treatment mean (in this case, $\bar{X}_{e}$ ) relative to the control treatment mean (in this case, $\bar{X}_{a}$ ) (Cooper and Hedges 1994). In a previous meta-analysis of the elevated $\mathrm{CO}_{2}$ literature, Curtis (1996) used the standardized difference between experimental and control means, the so-called $d$-index, as the estimate of $\mathrm{CO}_{2}$ effect size from a particular study. While the $d$-index had certain statistical advantages and was widely used in the social and medical sciences, it was not an effect size
Table 1 Categorical variables used in describing experimental conditions, and the values (levels) they could assume in the analysis of between-group heterogeneity $\left(Q_{b}\right)$. Note that Time and Pot were entered as continuous variables in the meta-database. There were additional Stress levels encountered in the $\mathrm{CO}_{2}$ literature but not considered in this analysis

\begin{tabular}{|c|c|c|c|c|c|c|c|c|}
\hline $\begin{array}{l}\text { Categorical } \\
\text { variable }\end{array}$ & $\begin{array}{l}\text { Level } \\
1\end{array}$ & $\begin{array}{l}\text { Level } \\
2\end{array}$ & $\begin{array}{l}\text { Level } \\
3\end{array}$ & $\begin{array}{l}\text { Level } \\
4\end{array}$ & $\begin{array}{l}\text { Level } \\
5\end{array}$ & $\begin{array}{l}\text { Level } \\
6\end{array}$ & $\begin{array}{l}\text { Level } \\
7\end{array}$ & $\begin{array}{l}\text { Level } \\
8\end{array}$ \\
\hline Stress & $\begin{array}{l}\text { None } \\
\text { (optimal } \\
\text { growth } \\
\text { conditions) }\end{array}$ & $\begin{array}{l}\text { Fert } \\
\text { (low } N \text { or } P \\
\text { treatment) }\end{array}$ & $\begin{array}{l}\text { Light } \\
\text { (low light } \\
\text { treatment) }\end{array}$ & $\begin{array}{l}\mathrm{O}_{3} \\
\text { (high ozone } \\
\text { treatment) }\end{array}$ & $\begin{array}{l}\text { UVB } \\
\text { (high UV-B } \\
\text { treatment) }\end{array}$ & $\begin{array}{l}\text { Temp } \\
\text { (low or high } \\
\text { temperature } \\
\text { treatment) }\end{array}$ & $\begin{array}{l}\mathrm{H}_{2} \mathrm{O} \\
\text { (drought } \\
\text { treatment) }\end{array}$ & $\begin{array}{l}\text { Comp } \\
\text { (competition } \\
\text { treatment) }\end{array}$ \\
\hline $\begin{array}{l}\text { Time } \\
\text { Func Grp } \\
\text { Pot } \\
\text { Method }\end{array}$ & $\begin{array}{l}\leq 59 \text { days } \\
\text { Angiosperm } \\
\leq 0.51 \\
\text { GC (indoor } \\
\text { growth } \\
\text { chamber) }\end{array}$ & $\begin{array}{l}\text { 60-99 days } \\
\text { Gymnosperm } \\
0.6-2.41 \\
\text { GH } \\
\text { (greenhouse) }\end{array}$ & $\begin{array}{l}100-365 \text { days } \\
\mathrm{N}_{2} \text { fixer } \\
2.5-91 \\
\text { OTC } \\
\text { (open-top } \\
\text { chamber) }\end{array}$ & $\begin{array}{l}>365 \text { days } \\
\geq 101 \\
\text { FACE } \\
\text { (free-air } \\
\mathrm{CO}_{2} \\
\text { enrichment) }\end{array}$ & $\begin{array}{l}\text { In ground } \\
\text { Branch } \\
\text { (branch } \\
\text { chamber) }\end{array}$ & & & \\
\hline
\end{tabular}


metric commonly used to assess responses to elevated $\mathrm{CO}_{2}$. A much more common effect size metric in elevated $\mathrm{CO}_{2}$ studies (as well as in other areas of ecology) is the response ratio, $r=\bar{X}_{e} / \bar{X}_{a}$. An impediment to the meta-analysis of response ratios, however, has been poor understanding of the sampling distribution of $r$ and the lack of any formal statistical methods for its integration across independent studies.

L.V. Hedges, J. Gurevitch, and P.S. Curtis (unpublished ms) have developed new statistical methods for the meta-analysis of response ratios. These methods have been incorporated into statistical software for performing meta-analyses (MetaWin, Rosenberg et al. 1996) and this software was used in the present study. In brief, $r$ first must be $\log$-transformed such that $l r=\ln (r)=$ $\ln \left(\bar{X}_{e}\right)-\ln \left(\bar{X}_{a}\right)$. If $\bar{X}_{e}$ and $\bar{X}_{a}$ are normally distributed and $\bar{X}_{a}$ is unlikely to be negative, then $\mathrm{l} r$ is approximately normally distributed with a mean of approximately the true response $\log$ ratio and variance, $v$, equal to

$v=\frac{S_{e}^{2}}{n_{e} \bar{X}_{e}^{2}}+\frac{s_{a}^{2}}{n_{a} \bar{X}_{a}^{2}}$

The $95 \%$ confidence interval for an individual log response ratio is then

$95 \% \mathrm{CI}=\mathrm{l} r-1.96 \sqrt{ } v$ to $\mathrm{l} r+1.96 \sqrt{ } v$

and the corresponding confidence limits for the unlogged response ratio obtained by computing their respective antilogs.

In summarizing results from independent studies, weighted means are normally used since individual experiments often differ in their statistical precision (e.g., Fig. 1). Giving greater weight to experiments whose estimates have greater precision (i.e.,- smaller standard error) will increase the precision of the combined estimate. The weighted mean $\log$ ratio $\left(\overline{r^{*}}\right)$ that produces the greatest precision (minimum variance) is

$\overline{\mathrm{I}}^{*}=\frac{\sum_{i=1}^{k} w_{i}^{*} \mathrm{i} r_{i}}{\sum_{i=1}^{k} w_{i}^{*}}$

where the weighting factor $w_{i}^{*}=1 /\left(v_{i}+\hat{\sigma}_{\lambda}^{2}\right)$ is the reciprocal of the total variance of $1 r_{i}$. Here, a mixed model analysis is assumed in which the pooled within-class variance, $\hat{\sigma}_{\lambda}^{2}$, is added to $v$ (Gurevitch and Hedges 1993).

Because each of the $k$ individual $\log$ ratios is approximately normally distributed, the weighted mean is normally distributed with confidence intervals calculated as in Eq. 2, where the standard error is

$S\left(\overline{1 r^{*}}\right)=\sqrt{1 / \sum_{i=1}^{k} w_{i}^{*}}$

Partitioning variance within and between groups

With meta-analysis, one can test whether categorical groups (e.g., angiosperms or gymnosperms) are homogeneous with respect to effect size (i.e., that observed differences in $1 r$ among studies are due to sampling error). and whether there are significant differences in mean response between those groups (Hedges and Olkin 1985). In a procedure analogous to the partitioning of variance in analysis of variance, the total heterogeneity for a group of comparisons $\left(Q_{T}\right)$ is partitioned into within-class heterogeneity $\left(Q_{w}\right)$ and between-class heterogeneity $\left(Q_{\mathrm{b}}\right)$, such that $Q_{\mathrm{T}}=Q_{\mathrm{w}}+Q_{\mathrm{b}}$. The $Q$ statistic follows a chi-square distribution, with $k-1$ degrees of freedom.

A central goal of our meta-analysis was to understand the source of variation in $\mathrm{CO}_{2}$ effect size among studies and to determine whether particular growth conditions or groups of species elicited quantitatively different responses. The approach we took was to partition total heterogeneity $\left(Q_{T}\right)$ within and between levels of each categorical variable. For example, the categorical variable Time (= length of the $\mathrm{CO}_{2}$ exposure) was partitioned into short ( $\leq 59$ days), medium (60-99 days), long (100-365 days) and very long ( $>365$ days) exposure periods (levels). Grouping the data according to Time classes we could test whether there was signifcant between-group heterogeneity with respect to $\mathrm{CO}_{2}$ exposure duration. This is analogous to examining the significance level of a particular source of variation in a conventional analysis of variance.

Partitioning of variance proceeded in two steps. First, betweengroup heterogeneity $\left(Q_{\mathrm{b}}\right)$ for each categorical variable was examined across all data for a given response variable. Second, the data set was subdivided according to levels of those categorical variables revealing significant $Q_{\mathrm{b}}$ and the first step repeated. Mean log ratios were calculated when the number of categorical variables exhibiting significant $Q_{b}$ had been reduced to one or zero, suggesting no further partitioning of the dataset was justified. Means were considered to be significantly different from one another if their $95 \%$ CIs were non-overlapping and were significantly different from zero if the $95 \% \mathrm{CI}$ did not overlap zero (Gurevitch and Hedges 1993).

\section{Results}

Biomass responses to elevated $\mathrm{CO}_{2}$ were strongly affected by environmental stress factors and to a lesser degree by duration of $\mathrm{CO}_{2}$ exposure and functional group affiliation (Table 2). Total biomass increased significantly at high $\mathrm{CO}_{2}(+28.8 \%, k=102$, Fig. 1) but there were also significant differences among stress categories (Fig. 2). Plants grown under nutrient stress showed only half the percentage growth stimulation $(+15.5 \%)$ of plants with no stress treatment $(+30.9 \%)$ and one-third that of plants grown under low light $(+52.3 \%)$. Examination of each of these sub-groups for other significant categorical divisions (e.g., Pot or Time) showed no additional significant between-group heterogeneity $\left(Q_{b}\right)$ (data not shown). This suggests that across all studies, there were significant differences in $\mathrm{CO}_{2}$ response among plants grown under different stress regimes, but not, for example, among those grown in different pot size classes. The small number of studies incorporating environmental stresses other than Fert and Light (e.g., O3, UVB, Temp) resulted in large confidence

Table 2 Between-group heterogeneity $\left(Q_{\mathrm{b}}\right)$ for $\mathrm{CO}_{2}$ effect size across five categorical variables for total biomass $\left(W_{\mathrm{T}}\right)$, belowground biomass $\left(W_{\mathrm{B}}\right)$, stem biomass $\left(W_{\mathrm{S}}\right)$, leaf biomass $\left(W_{\mathrm{L}}\right)$, net $\mathrm{CO}_{2}$ assimilation $(A)$, photosynthetic acclimation $\left(A_{\text {accl }}\right)$. stomatal conductance $\left(g_{\mathrm{s}}\right)$, leaf dark respiration $\left(R_{\mathrm{d}}\right)$, leaf starch concentration $\left(\mathrm{St}_{\mathrm{L}}\right)$, and leaf nitrogren concentration $\left(N_{\mathrm{L}}\right)$. The categorical variables and their levels are as in Table 1. Each response variable was represented by $k$ studies

\begin{tabular}{|c|c|c|c|c|c|c|}
\hline Variable & $k$ & Func Grp & Time & Pot & Method & Stress \\
\hline $\begin{array}{l}W_{\mathrm{T}} \\
W_{\mathrm{B}} \\
W_{\mathrm{S}} \\
W_{\mathrm{L}} \\
A \\
A_{\mathrm{acd}} \\
g_{\mathrm{S}} \\
R_{\mathrm{d}} \\
\mathrm{Si}_{\mathrm{L}} \\
N_{\mathrm{L}}\end{array}$ & $\begin{array}{r}102 \\
64 \\
47 \\
50 \\
79 \\
28 \\
48 \\
16 \\
17 \\
41\end{array}$ & $\begin{array}{l}0.23 \\
2.23 \\
1.94 \\
5.97^{*} \\
0.71 \\
0.24 \\
0.22 \\
0.26 \\
5.96^{*} \\
0.32\end{array}$ & $\begin{array}{l}3.75 \\
9.40^{*} \\
4.88 \\
5.60 \\
6.19 \\
3.64 \\
2.32 \\
1.46 \\
6.58 \\
6.39\end{array}$ & $\begin{array}{c}1.13 \\
3.20 \\
1.24 \\
2.58 \\
10.33^{*} \\
9.57^{*} \\
4.15 \\
3.15 \\
6.65^{*} \\
1.85\end{array}$ & $\begin{array}{l}2.03 \\
1.40 \\
1.10 \\
2.20 \\
7.91^{*} \\
3.64 \\
2.14 \\
2.46 \\
4.84 \\
1.35\end{array}$ & $\begin{array}{c}21.74^{* * *} \\
9.23^{*} \\
8.47^{*} \\
11.80^{* *} \\
1.20 \\
2.23 \\
1.34 \\
0.38 \\
7.46^{* *} \\
0.03\end{array}$ \\
\hline
\end{tabular}

* $P<0.05,{ }^{* *} P<0.01,{ }^{* * *} P<0.001$ 
limits and little power to draw statistical inferences regarding the relative magnitude of their mean effects.

Belowground biomass responses to $\mathrm{CO}_{2}$ were highly significant overall $(+38 \%, k=64)$ but were affected by environmental stress factors and length of the $\mathrm{CO}_{2}$ exposure (Table 2). Thus, there were significant time effects (across all stress types), but also significant stress effects (across all time categories). Further partitioning of this dataset showed that for plants exposed to no stress treatment, time categories were no longer significantly different nor was there any other significant $Q_{\mathrm{b}}$

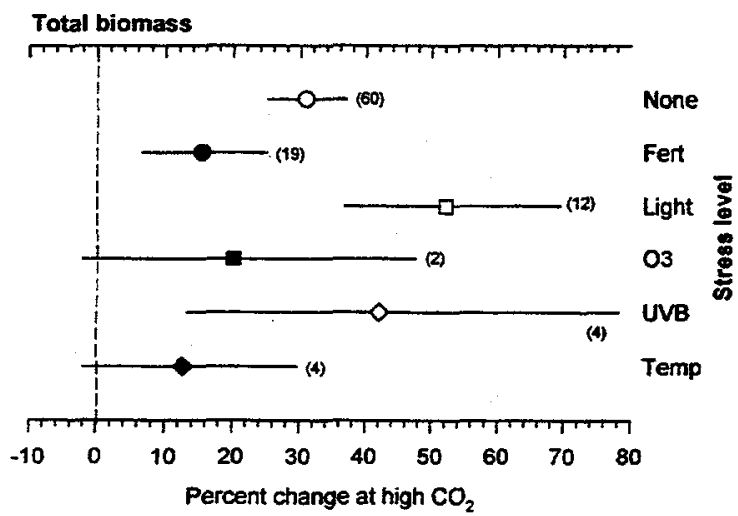

Fig. 2 The effect of environmental stress on the biomass response of trees to elevated $\mathrm{CO}_{2}$. Plants were exposed either to no stress (None), low nutrient availability (Fert), low light levels (Light), high ozone (O3), high UVB (UVB) or low or high temperature (Temp). Mean $\pm 95 \%$ confidence interval $(k)$

Table 3 Between-group heterogeneity $\left(Q_{b}\right)$ for subgroups of response variables presented in Table 2 . Data sets were partitioned according to the variable level in bold type, and $Q_{b}$ for all catego-

\begin{tabular}{|c|c|c|c|c|c|c|c|c|c|c|c|}
\hline Var & $k$ & $\begin{array}{l}\text { Stress } \\
\text { level }\end{array}$ & $\begin{array}{l}\text { Stress } \\
Q_{\mathrm{b}}\end{array}$ & $\begin{array}{l}\text { Time } \\
\text { level }\end{array}$ & $\begin{array}{l}\text { Time } \\
Q_{\mathrm{b}}\end{array}$ & $\begin{array}{l}\text { Func Grp } \\
\text { level }\end{array}$ & $\begin{array}{l}\text { Func Grp } \\
Q_{b}\end{array}$ & $\begin{array}{l}\text { Pot } \\
\text { level }\end{array}$ & $\begin{array}{l}\text { Pot } \\
Q_{\mathrm{b}}\end{array}$ & $\begin{array}{l}\text { Method } \\
\text { level }\end{array}$ & $\begin{array}{l}\text { Method } \\
Q_{\mathrm{b}}\end{array}$ \\
\hline$W_{\mathrm{B}}$ & 36 & None & - & All & 5.26 & $\begin{array}{l}\text { Angio, } \\
\text { Gymno }\end{array}$ & 0.01 & $1-4$ & 1.77 & All & 0.05 \\
\hline$W_{\mathrm{B}}$ & 25 & $\begin{array}{l}\text { Fert, UVB, } \\
\text { Light }\end{array}$ & 5.58 & 3,4 & $7.83^{* *}$ & $\begin{array}{l}\text { Angio, } \\
\text { Gymno }\end{array}$ & $4.62^{*}$ & $\begin{array}{l}1-3 \\
5\end{array}$ & 4.35 & All & 4.72 \\
\hline$W_{B}$ & 22 & $\begin{array}{l}\text { Fert, UVB, } \\
\text { Light }\end{array}$ & $12.44 * *$ & 3 & - & $\begin{array}{l}\text { Angio, } \\
\text { Gymno }\end{array}$ & 2.33 & $1-3$ & 0.61 & $\begin{array}{l}\mathrm{GC} \\
\mathrm{GH}\end{array}$ & 0.66 \\
\hline$W_{\mathrm{L}}$ & 37 & None & - & All & 4.78 & $\begin{array}{l}\text { Angio, } \\
\text { Gymno }\end{array}$ & 2.05 & All & 4.53 & All & 0.95 \\
\hline$W_{\mathrm{L}}$ & 10 & $\begin{array}{l}\text { Fert, } \\
\text { UVB }\end{array}$ & $5.38^{*}$ & 3 & - & $\begin{array}{l}\text { Angio, } \\
\text { Gymno }\end{array}$ & $6.69 * *$ & $1-3$ & $8.06^{*}$ & $\begin{array}{l}\mathrm{GC} \\
\mathrm{GH}\end{array}$ & $3.98^{*}$ \\
\hline$A$ & 59 & All & 0.90 & All & 5.78 & All & 0.12 & All & $11.31^{*}$ & $\begin{array}{l}\text { GH, } \\
\text { OTC }\end{array}$ & 2.78 \\
\hline$A$ & 50 & All & 0.80 & All & $8.94^{*}$ & All & 0.59 & $3-5$ & 4.49 & $\begin{array}{l}\text { GH, } \\
\text { OTC }\end{array}$ & 0.42 \\
\hline$A$ & 19 & $\begin{array}{l}\text { None, } \\
\text { Fert }\end{array}$ & 1.03 & $1-3$ & 0.43 & All & 4.04 & $1-4$ & 2.54 & GC & - \\
\hline$A_{\text {accl }}$ & 24 & None & - & All & 2.04 & All & 0.40 & $2-5$ & 0.53 & $\begin{array}{l}\text { GC, GH, } \\
\text { OTC }\end{array}$ & 1.15 \\
\hline $\mathrm{St}_{\mathrm{L}}$ & 12 & $\begin{array}{l}\text { None, } \\
\text { Fert }\end{array}$ & 0.90 & $1-3$ & 0.87 & Angio & - & $3-5$ & 0.92 & $\begin{array}{l}\text { GC, } \\
\text { OTC }\end{array}$ & 0.85 \\
\hline $\mathrm{St}_{\mathrm{L}}$ & 4 & $\begin{array}{l}\text { None, } \\
\text { Fert }\end{array}$ & $7.45^{* *}$ & 4 & - & Gymno & - & 4 & - & OTC & - \\
\hline
\end{tabular}

${ }^{*} P<0.05,{ }^{* *} P<0.01,{ }^{* * *} P<0.001$
(Table 3). It should be noted that as the data set was divided, not every categorical variable level was represented in each sub-group. For example, there was no pot level 5 (=planting in ground) represented in the 36 studies reporting $W_{\mathrm{B}}$ measurements in unstressed trees. In this group, $W_{\mathrm{B}}$ increased $41.5 \%$ under elevated $\mathrm{CO}_{2}$ (Fig. 3).

In contrast to the unstressed group, among all remaining $W_{B}$ studies (i.e., those including Fert, UVB, and

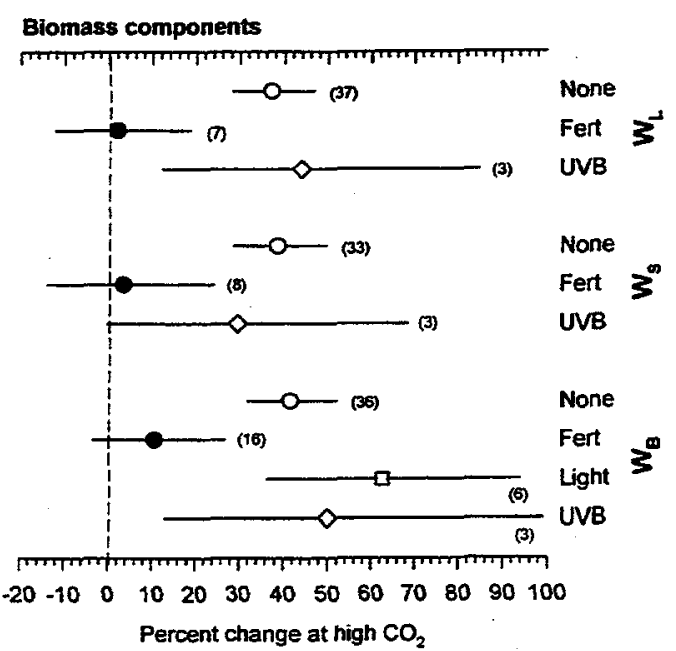

Fig. 3 The effect of elevated $\mathrm{CO}_{2}$ on biomass allocation to leaves $\left(W_{\mathrm{L}}\right)$, stem $\left(W_{\mathrm{S}}\right)$, or roots $\left(W_{\mathrm{B}}\right)$ in plants grown with (Fert, UVB, Light) or without (None) interacting stress conditions. Mean $\pm 95 \%$ confidence interval $(k)$

rical variables was then calculated. The specific levels represented for each categorial variable in the $k$ set of studies are also presented 
Light stress) there were significant Time and Func Grp effects but no significant differences among Stress categories (Table 3). Examination of these data revealed a small $(n=2)$ group of long-duration studies ( $>365$ days), both involving gymnosperms, whose belowground response was over twice that of the remaining 22 studies. Excluding those two studies (both from Johnson et al. 1994), which restricted Time to level 3 (100-365 days), resulted in a significant Stress $Q_{\mathrm{b}}$ but no other. That is, there were significant differences among Stress category means, but only after removal of the two outlier studies. While these two studies might well merit further examination (e.g., why were they outliers?), they were clearly distinct from the other 22 studies and obscured significant differences among Stress categories in that group. Below-ground biomass response to $\mathrm{CO}_{2}$ was not significantly different from zero under fertility stress $(+10.6 \%, \mathrm{~ns})$ and was not affected by low light or UVB stress relative. to unstressed plants although low sample sizes renders this latter conclusion very tentative (Fig. 3).

Leaf biomass responses to $\mathrm{CO}_{2}$ also showed signifcant $Q_{b}$ for several categorical variables. Across the entire dataset, leaf biomass increased significantly under high $\mathrm{CO}_{2}(+31 \%, k=50)$ but the magnitude of this response depended on both interacting stresses and on functional group affiliation (Table 2). Studies with no interacting stress treatment $(k=37)$ had no other significant $Q_{\mathrm{b}}$ (Table 3) and showed a mean stimulation of $W_{\mathrm{L}}$ under high $\mathrm{CO}_{2}$ of $37.1 \%$ (Fig. 3). The remaining ten studies showed significant variation among Stress (Fert, UVB), Func Grp (Angiosperm, Gymnosperm), Pot $(<0.5-91)$, and Method (GC, GH) levels. It was not possible to partition this variation completely since several categorical variables were confounded. For example, all four gymnosperm studies were conducted in growth chambers in pots $<2.51$. Stress treatments were not confounded with any other variable, however. Fertility stress reduced the $W_{1} C O_{2}$ response to zero while the magnitude of the $\mathrm{CO}_{2}$ response under UVB stress was not significantly different from that of unstressed plants (Fig. 3). Stem biomass response to $\mathrm{CO}_{2}$ showed a very similar pattern to $W_{\mathrm{B}}$ and $W_{\mathrm{L}}$ (Table 2 , Fig. 3), with unstressed plants having a highly significant response $(+38.6 \%, k=33)$ but with low soil fertility reducing this growth stimulation to zero.

There was no evidence for significant Stress, Time, or Func Grp effects on $A$ at high $\mathrm{CO}_{2}$ (Table 2), Pot and Method did, however, show significant $Q_{\mathrm{b}}$. For plants grown in GCs there was no Pot $Q_{\mathrm{b}}$ (Table 3 ) and an overall mean stimulation of $A$ of $27.5 \%$ at high $\mathrm{CO}_{2}$ (Fig. 4). For plants grown in GHs or OTCs and in pots $>2.4 \mathrm{~L}, A$ was stimulated $54.3 \%$ under $\mathrm{CO}_{2}$ enrichment (Table 3, Fig. 4), although there remained a significant Time $Q_{\mathrm{b}}$ for this group. The time effect was difficult to account for, with the level 3 mean (100-365 days) being greater than means from levels 1,2 , or 4 which were not different from one another (data not shown). Net $\mathrm{CO}_{2}$ assimilation in GH or OTC plants grown in pots $<2.51$ was significantly less $(19 \%, k=9)$ than in plants grown in larger pots or in the ground.

Elevated $\mathrm{CO}_{2}$ stimulation of $A$ in mature, opengrown Pinus taeda exposed to $c$. $55 \mathrm{~Pa} \mathrm{CO}_{2}$ for 2 years in a FACE experiment (Ellsworth et al. 1997) was $31 \%$, outside the $95 \% \mathrm{CI}$ of OTC and GH grown plants but very similar to the GC mean (Fig. 4). Part of the explanation for a reduced response relative to other 'fieldgrown' trees may be lower $\mathrm{CO}_{2}$ levels used in this free-air $\mathrm{CO}_{2}$ enrichment (FACE) study compared to most OTC experiments (c. $70 \mathrm{~Pa})$. Photosynthetic acclimation could also be more severe than in non-FACE systems (see below). With a sample size of one it is impossible to test for a "FACE effect" per se, and additional data are of great importance in resolving differences in the $\mathrm{CO}_{2}$ response, if any, between FACE-grown trees and those from the bulk of our other experimental systems.

Photosynthetic acclimation, calculated as the ratio of $A$ in elevated compared to ambient grown plants both measured at elevated $\mathrm{CO}_{2}$, was affected overall only by pot size, with plants in small pots $(<0.51)$, showing significant $A_{\text {accl }}(-36 \%, k=5)$, while plants grown in larger pots showed no evidence for $A_{\text {accl }}$ under any conditions (Tables 2, 3, Fig. 4). FACE-grown Pinus taeda showed $A_{\text {accl }}$ of $-16.5 \%$, outside the $95 \% \mathrm{CI}$ of other "large pot" studies. The likelihood of low water or nutrient supply contributing to the FACE $A_{\mathrm{accl}}$ response was low since Stress showed no significant $Q_{\mathrm{b}}$ in the overall data set. Increased sample size and estimates of among-FACE experiment variation clearly are needed to increase the power of these quantitative comparisons. Stomatal conductance showed a modest $(-11 \%)$ but not statistically significant reduction in plants grown under high $\mathrm{CO}_{2}$ while $R_{\mathrm{d}}$ (expressed on a leaf mass basis) was significantly reduced (-18\%) (Fig. 4). Neither $g_{\mathrm{s}}$ nor $R_{\mathrm{d}}$

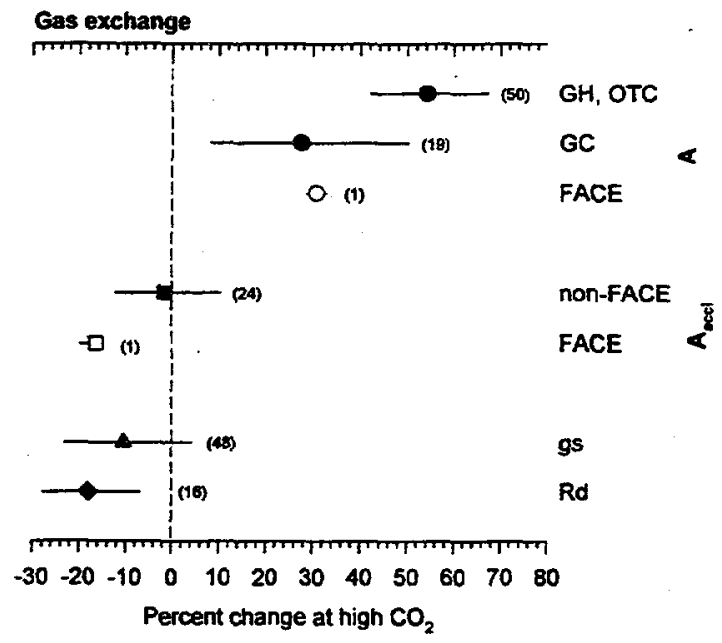

Fig. 4 Gas exchange responses of trees to elevated $\mathrm{CO}_{2}$. Net $\mathrm{CO}_{2}$ assimilation rate $(A)$, acclimation to elevated $\mathrm{CO}_{2}\left(A_{\text {acol }}\right)$, stomatal conductance $\left(g_{\mathrm{s}}\right)$ and leaf dark respiration $\left(R_{\mathrm{d}}\right)$ in plants grown under elevated compared to ambient $\mathrm{CO}_{2}$. Mean $\pm 95 \%$ confidence interval $(k)$ ( $G H$ greenhouse, $O T C$ field-based open-top chamber, $F A C E$ free-air $\mathrm{CO}_{2}$ enrichment, $G C$ growth chamber) 


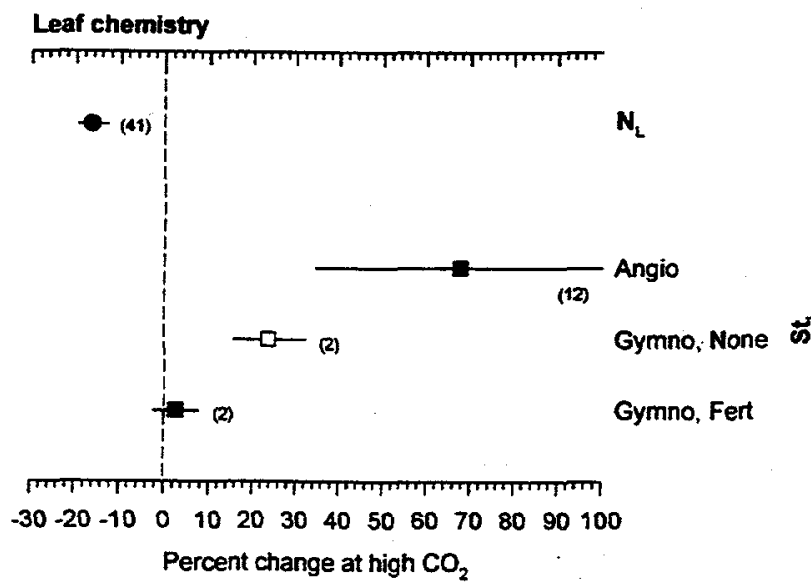

Fig. 5 Leaf nitrogen $\left(N_{\mathrm{L}}\right)$ and starch $\left(\mathrm{St}_{\mathrm{L}}\right)$ content in elevated compared to ambient $\mathrm{CO}_{2}$ grown plants. Both nitrogen and starch were reported on a tissue mass basis. Further subdivision of $\mathrm{St}_{\mathrm{L}}$ studies was by angiosperm (Angio) vs. gymnosperm (Gymno) and no interacting stress (None) vs. low-fertility stress (Fert). Mean $\pm 95 \%$ confidence interval $(k)$

responses were affected by any categorical variable (Table 2).

Leaf nitrogen (mass basis) showed a highly significant reduction at high $\mathrm{CO}_{2}(-16.4 \%$, Fig. 5) and this response was unaffected by Stress level or other categorical variables (Table 2). Leaf starch response to elevated $\mathrm{CO}_{2}$ was affected by Stress, Pot, and Func Grp (Table 2). In angiosperms, $\mathrm{St}_{\mathrm{L}}$ increased $67.6 \%$ at high $\mathrm{CO}_{2}$, significantly more than in unstressed $(+23.6 \%)$, or stressed (ns) gymnosperms (Fig. 5).

\section{Discussion}

Our meta-analysis of $\mathrm{CO}_{2}$ responses in trees leads to a number of conclusions that we can state with considerable certainty, being based on many independent studies sharing numerous experimental design features. In particular, it is clear that both $A$ and $W_{\mathrm{T}}$ increase significantly at twice ambient $\mathrm{CO}_{2}$, regardless of growth conditions. These results agree qualitatively with other reviews of this literature, but our quantitative summary of $\mathrm{CO}_{2}$ effect sizes often differ significantly from earlier estimates. For example, our $\mathrm{CO}_{2}$ effect size estimate of $+31 \%$ for $W_{\mathrm{T}}$ under non-stressed, control conditions was less than half the $\mathrm{CO}_{2}$ effect calculated by McGuire et al. (1995). In their review of 77 studies of elevated $\mathrm{CO}_{2}$ involving $\mathrm{N}$ manipulations they found a $71 \%$ biomass increase in high $\mathrm{CO}_{2}$, higher $\mathrm{N}$ treatment trees compared to ambient $\mathrm{CO}_{2}$, higher $\mathrm{N}$ treatment trees. However, as their results were drawn only from studies involving soil $\mathrm{N}$ manipulations, the higher $\mathrm{N}$ and lowest $\mathrm{N}$ treatments could have provided greater soil $\mathrm{N}$ than the typical nostress and low fertility treatments respectively in our analysis. Interestingly, the $50 \%$ relative reduction in the $\mathrm{CO}_{2}$ growth response calculated by McGuire et al.
(1995) as due to low soil $\mathrm{N}$ availability (i.e., only a $35 \%$ growth enhancement in the lowest $\mathbf{N}$ treatments) was identical to our observation of a $50 \%$ reduction in $\mathrm{CO}_{2}$ stimulation of $W_{T}$ in nutrient-stressed plants $(+16 \%)$. Eamus and Jarvis (1989) also estimated a significantly greater biomass response to elevated $\mathrm{CO}_{2}(+40 \%)$ than we found, while Ceulemans and Mousseau (1994) distinguished between the $\mathrm{CO}_{2}$ growth response of conifers $(+38 \%)$ and broadleaved species $(+68 \%)$, a division with no statistical basis in our dataset. Lastly, Wullschleger et al. (1995) calculated virtually the same overall dry weight response to $\mathrm{CO}_{2}$ in unstressed plants $(+32 \%, k=295)$ as we did, but found no reduction in this response under low nutrient conditions $(+30 \%$, $k=82$ ).

These reviews differ from one another in many respects, including their overall objectives, their scope, and the collection of literature under consideration. It is difficult, therefore, to identify precisely the component(s) responsible for these differences in $\mathrm{CO}_{2}$ effect size estimates. A contributing factor certainly must be basic differences in the authors' approach to quantitative research integration and the statistical tools (or lack thereof) that were used. To the extent that resolving differences of 2-3 fold in our estimates of $\mathrm{CO}_{2}$ effects on tree growth is of importance (and we suggest it is) we must abandon ad hoc or ill-defined concepts for summarizing independent research results in favor of statistically robust meta-analytic methods. Only then will we be able to critically evaluate competing estimates of the likely magnitude of $\mathrm{CO}_{2}$ stimulated tree growth on, for example, low nutrient soils, or the relative importance of taxonomic or functional group affiliation in the $\mathrm{CO}_{2}$ response.

There has been considerable debate whether $\mathrm{CO}_{2}$ enrichment results in shifts in root:shoot ratio $(R / S)$ and, if so, under what conditions this occurs. Biomass allocation models such as functional balance (Davidson 1969) and carbon/nutrient substrate ratio (Reynolds and Thornley 1982) predict that as tissue $C: N$ ratios rise and $\mathrm{N}$ becomes more limiting relative to $\mathrm{C}$, biomass allocation to roots will increase. Thus, high $\mathrm{CO}_{2}$ should elicit similar shifts in R/S as does low soil N. Evidence for such a $\mathrm{CO}_{2}$ effect in trees has been equivocal, however. Eamus and Jarvis (1989) considered the bulk of the evidence to indicate an increase in $R / S$, particularly under low nutrient conditions, a conclusion supported by Ceulemans and Mousseau (1994). Norby (1994) observed that $\mathrm{CO}_{2}$ effects on root allocation could easily be confounded with $\mathrm{CO}_{2}$ effects on developmental rate and he estimiated a modest $(+6 \%)$ increase in $\mathrm{R} / \mathrm{S}$ at high $\mathrm{CO}_{2}$, with no differential response under nutrient stress. Similarly, neither McGuire et al. (1995) nor Wullschleger et al. (1995) found evidence for a significant $\mathrm{CO}_{2}$ effect on biomass allocation under any conditions. We analyzed $\mathrm{CO}_{2}$ effects on individual biomass components rather than $\mathrm{R} / \mathrm{S}$, which are rarely reported with error estimates, and found little evidence to support signifcant shifts in allocation, whether to leaves, stems, or 
roots, under most environmental or cultural conditions. The only condition under which allocation might shift in favor of roots was nutrient stress, but this response was not statistically significant. It is interesting to note, however, that the $\mathrm{CO}_{2}$ effect on $W_{\mathrm{T}}$ under nutrient stress although reduced was still significant and the only biomass component with a similar mean $\mathrm{CO}_{2}$ effect size under nutrient stress was $W_{\mathrm{B}}$. This observation lends qualified support to predictions of increased $R / S$ at high $\mathrm{CO}_{2}$ under low soil nutrient availability but additional data clearly will be needed to resolve this important issue.

There is broad agreement among reviewers on the overall magnitude of tree photosynthetic responses to $\mathrm{CO}_{2}$ enrichment, although less so on factors affecting that response. Estimates of overall $\mathrm{CO}_{2}$ effects on $\mathrm{A}$ range from $+44 \%$ (Gunderson and Wullschleger 1994) to $+54 \%$ (this study). Low soil nutrients have often been considered of primary importance in reducing the magnitude of this response (e.g., McGuire et al. 1995; Curtis 1996) but rarely have the relative effects of other environmental factors been compared quantitatively to that of soil nutrients. We found significant Pot and Method $Q_{b}$ across all 79 studies in our database but no significant differences among stress categories. However, of $50 \mathrm{GH}$ and OTC studies that were conducted in large pots or in the ground, only 7 involved low nutrient treatments, a small sample conveying relatively little statistical power. While our failure to detect significant nutrient effects may be due to sampling error, this example illustrates a general concern that must be confronted by quantitative reviewers of the literature on the effects of elevated $\mathrm{CO}_{2}$. That is, all identifiable sources of variation in a dataset must be examined before summary statistics are calculated and conclusions drawn. If this is not done, variation due to one factor (e.g., pot size) may be confounded with that of another (e.g., soil nutrients), leading to inaccurate or erroneous conclusions regarding the importance of either factor. This is particularly true for studies with elevated $\mathrm{CO}_{2}$ where cultural conditions are known to affect the magnitude of the treatment response (Thomas and Strain 1991; McConnaughay et al. 1993; Kennedy 1995). Our results clearly show that environmental stress is of less importance than certain cultural factors in altering the magnitude of photosynthetic responses to high $\mathrm{CO}_{2}$ and that significant, sustained increases in $A$ can be expected in trees as atmospheric $\mathrm{CO}_{2}$ levels rise.

Photosynthetic acclimation, or down-regulation, represents a suite of physiological processes which cause photosynthetic capacity in plants grown under high $\mathrm{CO}_{2}$ to decline relative to plants grown under ambient $\mathrm{CO}_{2}$ (Stitt 1991). To evaluate the magnitude of $A_{\text {acod }}$ in trees grown under high $\mathrm{CO}_{2}$ we adopted the convention suggested by Gunderson and Wullschleger (1994) of comparing $A$ in plants grown under elevated and ambient $\mathrm{CO}_{2}$ measured at a common $\mathrm{CO}_{2}$ level (either internal or external to the leaf). Our results show no consistent evidence for $A_{\text {accl }}(-1 \%$, ns), except in trees grown in pots $<0.51(-36 \%, P<0.01)$. This is in contrast to both the prevailing view based on narrative reviews (Ceulemans and Mousseau 1994; McGuire et al. 1995 ) and the overall $21 \%$ acclimation response across 20 studies reported by Gunderson and Wullschleger (1994). The 24 "larger pot" studies remaining in our dataset were almost evenly divided among those showing strong $A_{\text {accl }}$ (e.g., Johnsen 1993; Curtis et al. 1995), no $A_{\text {accl }}$ (e.g., Downton et al. 1990; Grulke et al. 1993), and significant up-regulation (e.g., Kaushal et al. 1989; Sharkey et al. 1991). Given the heterogeneity of this group, and the small number of studies with common stress treatments, we suggest it is premature to conclude that photosynthetic acclimation is a universal response by trees to growth under high $\mathrm{CO}_{2}$ under any particular set of conditions. Additional results from forest FACE experiments could help define those conditions but within and among-study variance estimates will be required for any rigorous statistical tests to be made.

Interpreting the effects of elevated $\mathrm{CO}_{2}$ on tree $\mathrm{gs}_{\mathrm{s}}$ presents similar problems to those raised regarding $A_{\text {accl }}$. Reviewers of data on $g_{\mathrm{s}}$ responses, including measurements from herbaceous species, generally suggest a significant reduction in $g_{s}$ to be the norm, with the well documented sensitivity of stomata to internal $\mathrm{CO}_{2}$ level (Farquhar and Sharkey 1982) offered as a plausible response mechanism. Acclimation of $g_{\mathrm{s}}$ to high $\mathrm{CO}_{2}$ is a possibility, however, and while no physiological mechanism for acclimation has been proposed, one result of acclimation could be a change in stomatal sensitivity to $\mathrm{CO}_{2}$ (Sage 1994). Eamus and Jarvis (1989) estimated a reduction of from $-10 \%$ to $-60 \%$ in $g_{s}$ of trees grown under elevated compared to ambient $\mathrm{CO}_{2}$ but acknowledged numerous exceptions. We found considerable variation in the magnitude of $\mathrm{CO}_{2}$ effects on $g_{\mathrm{s}}$ as well. Although the overall mean response across 48 studies was a modest $-11 \%$, this effect was not statistically different from zero, nor were there significant stress or cultural modifiers to this response. As with the distribution of $A_{\text {accl }}$ values, our $g_{\mathrm{s}}$ dataset contained numerous studies reporting strongly negative (e.g., Bassow et al. 1994; Eamus et al. 1995), not statistically signifcant (e.g., Hollinger 1987; Bunce 1992), and strongly positive (e.g., Norby and O'Neill 1991; Pettersson and McDonald 1992) effects of high $\mathrm{CO}_{2}$ on $g_{s}$. Additional data will be required before we can state with certainty either the magnitude or the direction of $\mathrm{CO}_{2}$ effects on tree $g_{s}$.

In contrast to the uncertainty regarding $\mathrm{CO}_{2}$ effects on $A_{\text {acel }}$ and $g_{s}$, our analysis provides strong support and robust summary statistics for the widely accepted view (e.g., Amthor 1994; Wullschleger et al. 1994) that growth at elevated $\mathrm{CO}_{2}$ results in significant reductions in $R_{\mathrm{d}}$ and $N_{\mathrm{L}}$ when both are expressed on a tissue mass basis. Working with a similar, though somewhat smaller dataset, Curtis (1996) found reduced $N_{\mathrm{L}}$ when reported on a leaf mass but not when reported on a leaf area basis, suggesting that in most circumstances the massbased $\mathrm{N}$ reduction under $\mathrm{CO}_{2}$ enrichment was due to increased leaf density rather than $\mathrm{N}$ reallocation. In the 
present study we documented large increases in $S t_{L}$ under all conditions except in nutrient stressed gymnosperms. Given the strong positive relationship between tissue $\mathrm{N}$ content and both photosynthesis (Field and Mooney 1986) and maintenance respiration (Ryan 1991) it is important to determine when growth at high $\mathrm{CO}_{2}$ leads to a net decrease in non-storage leaf $\mathrm{N}$ content as opposed to reduced leaf $\mathrm{N}$ concentration due to changes in specific leaf area. The extent to which $\mathrm{CO}_{2}$ enrichment leads to functional decreases in $N_{\mathrm{L}}$ could be an important determinant of long-term growth and allocational responses to elevated $\mathrm{CO}_{2}$ (Luo et al. 1994). It is also important to determine whether reduced $N_{\mathrm{L}}$ of green leaves carries over into an increased C: $N$ ratio of naturally senesced leaf litter. Although evidence that elevated $\mathrm{CO}_{2}$ alters leaf decomposition rates is at present equivocal (O'Neill and Norby 1996), reduced N mineralization from soil organic matter could provide a potent negative feedback on long-term forest productivity with rising $\mathrm{CO}_{2}$ (Zak et al. 1993).

It is important to note that no single meta-analysis is likely to be definitive, and that multiple approaches and perspectives should be encouraged. For example, while our conclusions regarding $\mathrm{CO}_{2}$ effects on $A, A_{\text {accl}}$, and $g_{s}$ are in broad agreement with those of Curtis (1996), the differences in effect size metric ( $r$ vs. $d$-index) and in the strategies for partitioning within and between group variance in the two meta-analyses resulted in several qualitatively different outcomes. The most important was for $A_{\text {accl}}$, where Curtis (1996, Fig. 3a) found a highly significant (although numerically modest) overall $\mathrm{CO}_{2}$ effect, while in the present study we found no $\mathrm{CO}_{2}$ effect in non-FACE studies (Fig. 4). However, the overall mean effect size estimate in Curtis (1996) included the responses of plants grown in small pots $(<0.51)$ which were shown in both studies to have significantly greater $A_{\text {accl }}$ than plants grown in larger pots. Here, these plants were excluded from the overall analysis, leading to the result of no significant $A_{\text {accl }}$. In addition, where the number of studies within a category is small, as was the case in numerous instances here, it is particularly important to repeat the meta-analysis as new data becomes available.

In conclusion, quantitative integration of the elevated $\mathrm{CO}_{2}$ literature has been hampered by inappropriate sampling and statistical methods, leading to uncertainty in the magnitude of $\mathrm{CO}_{2}$ effects on fundamental processes controlling carbon gain in woody vegetation and of the importance of environmental factors in altering the magnitude of these effects. Statistically defensible methods of integrating diverse research results have been developed over the past 50 years and are now firmly. in place in the medical and social sciences (Mann 1990). Meta-analysis is not a substitute for well designed, multi-factorial experiments and it is important to acknowledge the limits to establishing causal relationships from meta-analytic results where categorical groups created by the meta-analyst were not randomly assigned treatments within the primary studies (Miller and Pol- lock 1994). What meta-analysis does offer is.an objective and statistically rigorous methodology for integrating primary research results with the goal of estimating the magnitude of treatment effects within and among categorical groups. We suggest that it is important from a scientific as well as a policy perspective that elevated $\mathrm{CO}_{2}$ research results continue to be integrated using these tools.

Ackmowledgeinents We thank Kennetha Mays for assistance in data input and members of the working group on Meta Analysis, Interaction Strength and Effect Size at the National Center for Ecological Analysis and Synthesis for many helpful discussions. This work was supported by the interagency program on Terrestrial Ecosystems and Global Change, USDA grant no. 9504800 to P.S.C.

\section{Appendix 1 References to works included in the database}

Arnone JA III, Gordon JC (1990) Effect of nodulation, nitrogen fixation and $\mathrm{CO}_{2}$ enrichment on the physiology, growth and dry mass allocation of seedlings of Alnus rubra Bong. New Phytol 116:55-66

Bassow SL, McConnaughay KDM, Bazzaz FA (1994) The response of temperate tree seedlings grown in elevated $\mathrm{CO}_{2}$ to extreme temperature events. Ecol Appl 4:593-603

Bazzaz FA, Miao SL (1993) Successional status, seed size, and responses of tree seedlings to $\mathrm{CO}_{2}$, light and nutrients. Ecology 74:104-112

Bazzaz FA, Miao SL, Wayne PM (1993) $\mathrm{CO}_{2}$-induced growth enhancements of co-occuring tree species decline at different rates. Oecologia 96:478-482

Berryman CA, Eamus D, Duff GA (1993) The influence of $\mathrm{CO}_{2}$ enrichment on growth, nutrient content and biomass allocation of Maranthes corymbosa. Aust J Bot 41:195-209

Brown KR (1991) Carbon dioxide enrichment accelerates the decline in nutrient status and relative growth rate of Populus tremuloides Michx. seedlings. Tree Physiol 8:161-173

Bunce JA (1992) Stomatal conductance, photosynthesis and respiration of temperate deciduous tree seedlings grown outdoors at an elevated concentration of carbon dioxide. Plant Cell Environ 15:541-549

Callaway RM, DeLucia EH, Thomas EM, Schlesinger WH (1994) Compensatory responses of $\mathrm{CO}_{2}$ exchange and biomass allocation and their effects on the relative growth rate of ponderosa pine in different $\mathrm{CO}_{2}$ and temperature regimes. Oecologia. 98:159-166

Cipollini ML, Drake BG, Whigham D (1993) Effects of elevated $\mathrm{CO}_{2}$ on growth and carbon/nutrient balance in the deciduous woody shrub Lindera benzoin (1.) Blume (Lauraceae). Oecologia 96:339-346

Conroy JP, Kuppers M, Kuppers B, Virgona J, Barlow EWR (1988) The influence of $\mathrm{CO}_{2}$ enrichment, phosphorus deficiency and water stress on the growth, conductance and water use of Pinus radiata D. Don. Plant Cell Environ 11:91-98

Couteaux MM, Bottner P, Rouhier H, Billes G (1992) Atmospheric $\mathrm{CO}_{2}$ increase and plant material quality: production, nitrogen allocation and litter decomposition of sweet chestnut. In: Teller A, Mathy P, Jeffers JNR (eds) Responses of forest ecosystems to environmental changes. Elsevier, London, pp 429-436

Curtis PS, Teeri JA (1992) Seasonal reponses of leaf gas exchange to elevated carbon dioxide in Populus grandidentata. Can J For Res 22:1320-1325

Curtis PS, Vogel CS, Pregitzer KS, Zak DR, Teeri JA (1995) Interacting effects of soil fertility and atmospheric $\mathrm{CO}_{2}$ on leaf area growth and carbon gain physiology in Populus euramericana (Dode) Guinier. New Phytol 129:253-263

Curtis PS, Zak DR, Pregitzer KS, Teeri JA (1994) Above- and belowground response of Populus grandidentata to elevated atmospheric $\mathrm{CO}_{2}$ and soil $\mathrm{N}$ availability. Plant Soil 165:45-51 
Downton WJS, Grant WJR, Chacko EK (1990) Effect of elevated carbon dioxide on the photosynthesis and early growth of Mangosteen (Garcinia mangostana L.). Sci Hort 44:215-225

Downton WJS, Grant WJR, Loveys BR (1987) Carbon dioxide enrichment increases yield of valencia orange. Aust J Plant Physiol 14:493-501

Eamus D, Berryman CA, Duff GA (1993) Assimilation, stomatal conductance, specific leaf area and chlorophyll responses to elevated $\mathrm{CO}_{2}$ of Maranthes corymbosa a tropical rain forest species. Aust J Plant Physiol 20:741-755

Eamus D, Berryman CA, Duff GA (1995a) The impact of $\mathrm{CO}_{2}$ enrichment on water relations in Maranthes corymbosa and Eucalyptus tetrodonta. Aust J Bot 43:273-282

Eamus D, Duff GA, Berryman CA (1995b) Photosynthetic responses to temperature, light fiux density, $\mathrm{CO}_{2}$ concentration and vapour pressure deficit in Eucalyptus tetrodonta grown under $\mathrm{CO}_{2}$ enrichment. Environ Pollut 90.41-49

El Kohen A, Pontailler J-Y, Mousseau M (1991) Effect of doubling of atmospheric $\mathrm{CO}_{2}$ concentration on dark respiration in aerial parts of young chestnut trees (Castanea sativa Mill.). C R Sci Paris 312:477-481

El Kohen A, Rouhier H, Mousseau M (1992) Changes in dry weight and nitrogen partitioning induced by elevated $\mathrm{CO}_{2}$ depend on soil nutrient availability in sweet chestnut (Castanea sativa Mill.). Ann Sci For 49:83-90

El Kohen A, Venet L, Mousseau M (1993) Growth and photosynthesis of two deciduous forest species at elevated carbon dioxide. Func Ecol 7:480-486

Ellsworth DS, LaRoche J, Hendrey GR (1997) Photosynthesis and leaf nitrogen in a maturing pine forest under free-air $\mathrm{CO}_{2}$ enrichment (FACE) (Report BNL \#61741). Department of Applied Science, Brookhaven National Laboratory, Upton

Ferguson JJ, Avigne WT, Allen LH, Koch KE (1986) Growth of $\mathrm{CO}_{2}$-enriched sour orange seedlings treated with Gibberellins/ Cytokinins. Proc Fl State Hort Soc 99:37-39

Fetcher N, Jaeger CH, Strain BR, Sionit N (1988) Long-term elevation of atmospheric $\mathrm{CO}_{2}$ concentration and the carbon exchange rates of saplings of Pinus taeda $\mathrm{L}$. and Liquidambar styracifua L. Tree Physiol 4:255-262

Garcia RL, Idso SB, Wall GW, Kimball BA (1994) Changes in net photosynthesis and growth of Pinus eldarica seedlings in response to atmospheric $\mathrm{CO}_{2}$ enrichment. Plant Cell Environ 17:971-978

Gaudiliere J-P, Mousseau M (1989) Short term effect of $\mathrm{CO}_{2}$ enrichment on leaf development and gas exchange of young poplars (Populus euramericana cv 1 214). Acta Oecol Oecol Plant 10:95-105

Gorissen A, Kuikman PJ, Van De Beek H (1995) Carbon allocation and water use in juvenile Douglas fir under elevated $\mathrm{CO}_{2}$ New Phytol 129:275-282

Grulke NE, Hom JL, Roberts SW (1993) Physiological adjustment of two full-sib families of ponderosa pine to elevated $\mathrm{CO}_{2}$. Tree Physiol 12:391-401

Gunderson CA, Norby RJ. Wullschleger SD (1993) Foliar gas exchange responses of two deciduous hardwoods during 3 years of growth in elevated $\mathrm{CO}_{2}$ : no loss of photosynthetic enhancement. Plant Cell Environ 16:797-807

Hollinger DY (1987) Gas exchange and dry matter allocation responses to elevation of atmospheric $\mathrm{CO}_{2}$ concentration in seedlings of three tree species. Tree Physiol 3:193-202

Idso SB, Kimball BA (1993) Effects of atmospheric $\mathrm{CO}_{2}$ enrichment on net photosynthesis and dark respiration rates of three Australian tree species. J Plant Physiol 141:166-171

Idso SB, Kimball BA. Allen SG (1991) Net photosynthesis of sour orange trees maintained in atmospheres of ambient and elevated $\mathrm{CO}_{2}$ concentration. Agric For Meteorol 54:95-101

Jarvis PG, Lee HSJ, Barton CVM (1994) The likely impact of rising $\mathrm{CO}_{2}$ and temperature on European forests. Institute of Ecology and Resource Management. University of Edinburgh. Edinburgh

Johnsen KH (1993) Growth and ecophysiological responses of black spruce seedlings to elevated $\mathrm{CO}_{2}$ under varied water and nutrient additions. Can J For Res 23:1033-1042
Johnson D, Geisinger D, Walker R, Newman J, Vose J, Elliot K, Ball $T$ (1994) Soil $\mathrm{pCO}_{2}$, soil respiration, and root activity in $\mathrm{CO}_{2}$-fumigated and nitrogen-fertilized pondersosa pine. Plant Soil 165:129-138

Kaushal P, Guehl JM, Aussenac G (1989) Differential growth response to atmospheric carbon dioxide enrichment in seedlings of Cedrus atlantica and Pinus nigra ssp. Laricio var. Corsicana. Can J For Res 19:1351-1358

Kubiske ME, Pregitzer KS (1996) Effects of elevated $\mathrm{CO}_{2}$ and light availability on the photosynthetic light response of trees of contrasting shade tolerance. Tree Physiol 16:351-358

Lemeur R, Lootens P, Debruyckere E (1992) Effect of increased atmospheric $\mathrm{CO}_{2}$ concentration on primary productivity and carbon allocation in typical Belgian forest ecosystems (Progress report 1992, to the Belgium Impulse Programme Global Change). University of Ghent, Ghent

Lewis JD, Thomas RB, Strain BR (1994) Effect of elevated $\mathrm{CO}_{2}$ on mycorrhizal of loblolly pine seedlings. Plant Soil 165:81-88

Lindroth RL, Kinney KK, Platz CL (1993) Responses of deciduous trees to elevated atmospheric $\mathrm{CO}_{2}$ : productivity, phytochemistry, and insect performance. Ecology 74:763-777

Liu S, Teskey RO (1995) Responses of foliar gas exchange to longterm elevated $\mathrm{CO}_{2}$ concentrations in mature loblolly pine trees. Tree Physiol 15:351-359

Marek MV, Kalina J, Matouskova M (1995) Response of photosynthetic carbon assimilation of Norway spruce exposed to long-term elevation of $\mathrm{CO}_{2}$ concentration. Photosynthetica 31:209-220

Mortensen LM (1994) Effects of carbon dioxide concentration on assimilate partitioning, photosynthesis and transpiration of Betula pendula roth. and Picea abies (L.) Karst. seedlings at two temperatures. Acta Agric Scand B Soil Plant Sci 44:164-169

Mortensen LM (1995) Effect of carbon dioxide concentration on biomass production and partitioning in (Betula pubescens Ehrh.) seedlings at different ozone and temperature regimes. Environ Pollut 87:337-343

Mousseau M (1993) Effects of elevated $\mathrm{CO}_{2}$ on growth, photosynthesis and respiration of sweet chestnut (Castanea sativa Mill.). Vegetatio 104/105:413-419

Mousseau M, Enoch HZ (1989) Carbon dioxide enrichment reduces shoot growth in sweet chestnut seedlings (Castanea sativa Mill.). Plant Cell Environ 12:927-934

Norby RJ, Gunderson CA, Wullschleger SD, O'Neill EG, McCracken MK (1992) Productivity and compensatory responses of yellow-poplar trees in elevated $\mathrm{CO}_{2}$. Nature 357:322-324

Norby RJ, O'Neill EG (1989) Growth dynamics and water use of seedlings of Quercus alba $\mathrm{L}$. in $\mathrm{CO}_{2}$-enriched atmospheres. New Phytol 111:491-500

Norby RJ, O'Neill EG (1991) Leaf area compensation and nutrient interactions in $\mathrm{CO}_{2}$-enriched seedlings of yellow-poplar (Liriodendron tulipifera L.). New Phytol 117:515-528

Norby RJ, O'Neill EG, Hood WG, Luxmoore RJ (1987) Carbon allocation, root exudation and mycorrhizal colonization of Pinus echinata seedlings grown under $\mathrm{CO}_{2}$ enrichment. Tree Physiol 3:203-210

Norby RJ, O'Neill EG, Luxmoore RJ (1986) Effects of atmospheric $\mathrm{CO}_{2}$ enrichment on the growth and mineral nutrition of Quercus alba seedlings in nutrient-poor soil. Plant Physiol 82:83-89

Norby RJ, Wullschleger, Gunderson CA (1996) Tree responses to elevated $\mathrm{CO}_{2}$ and implications for forests. In: Koch $\mathrm{GW}$ Mooney HA (eds) Carbon dioxide and terrestrial ecosystems. Academic Press, New York, pp 1-21

O'Neill EG, Luxmoore RJ, Norby RJ (1987) Increases in mycorrhizal colonization and seedling growth in Pinus echinato and Quercus alba in an enriched $\mathrm{CO}_{2}$ atmosphere. Can J For Res 17:878-883

Pettersson R, McDonald AJS (1992) Effects of elevated carbon dioxide concentration on photosynthesis and growth of small birch plants (Betula pendula Roth.) at optimal nutrition. Plant Cell Environ 15:911-919 
Pettersson R, McDonald AJS, Stadenberg I (1993) Response of small birch plants (Betula pendula Roth.) to elevated $\mathrm{CO}_{2}$ and nitrogen supply. Plant Cell Environ 16:1115-1121

Polle A, Pfirmann T, Chakrabarti S, Rennenberg H (1993) The effects of enhanced ozone and enhanced carbon dioxide concentrations on biomass, pigments and antioxidative enzymes in spruce seedlings. Plant Cell Environ 16:311-316

Pregitzer KS, Zak DR. Curtis PS, Kubiske ME. Teeri JA, Vogel CS (1995) Atmospheric $\mathrm{CO}_{2}$, soil nitrogen and turnover of fine roots. New Phytol 129:579-585

Reekie EG, Bazzaz FA (1989) Competition and patterns of resource use among seedlings of five tropical trees grown at ambient and elevated $\mathrm{CO}_{2}$. Oecologia 79:212-222

Reid CD, Strain BR (1994) Effects of $\mathrm{CO}_{2}$ enrichment on wholeplant carbon budget of seedlings of Fagus grandifolia and Acer saccharum in low irradiance. Oecologia 98:31-39

Rochefort L, Bazzaz FA (1992) Growth response to elevated $\mathrm{CO}_{2}$ in seedlings of four co-occurring birch species. Can J For Res 22:1583-1587

Roth SK, Lindroth RL (1994) Effects of $\mathrm{CO}_{2}$-mediated changes in paper birch and white pine chemistry on gypsy moth performance. Oecologia 98:133-138

Sharkey TD, Loreto F, Delwiche CF (1991) High carbon dioxide and sun/shade effects on isoprene emission from oak and aspen tree leaves. Plant Cell Environ 14:333-338

Stewart JD, Hoddinott J (1993) Photosynthetic acclimation to elevated atmospheric carbon dioxide and UV irradiation in Pinus banksiana. Physiol Plant 88:493-500

Sullivan JH, Teramura AH (1994) The effects of UV-B radiation on loblolly pine. Plant Cell Environ 17:311-317

Surano KA, Daley PF, Houpis JLJ, Shinn JH, Helms JA, Palassou RJ, Costella MP (1986) Growth and physiological responses of Pinus ponderosa Dougl. ex P. Laws. to long-term elevated $\mathrm{CO}_{2}$ concentration. Tree Physiol 2:243-259

Teskey RO (1995) A field study of the effects of elevated $\mathrm{CO}_{2}$ on carbon assimilation, stomatal conductance and leaf branch growth of Pinus taeda trees. Plant Cell Environ 18:565-573

Thomas RB, Richter DD, Ye H, Heine PR, Strain BR (1991) Nitrogen dynamics and growth of seedlings of an $\mathrm{N}$-fixing tree
(Gliricidia sepium (Jacq.) Walp.) exposed to elevated atmospheric carbon dioxide. Oecologia 88:415-421

Tissue DT, Thomas RB, Strain BR (1993) Long-term effects of elevated $\mathrm{CO}_{2}$ and nutrients on photosynthesis and rubisco in loblolly pine seedlings. Plant Cell Environ 16:859-865

Tschaplinski TJ, Norby RJ, Wullschleger SD (1993) Responses of loblolly pine seedlings to elevated $\mathrm{CO}_{2}$ and fluctuating water supply. Tree Physiol 13:283-296

Vogel CS, Curtis PS (1995) Leaf gas exchange and nitrogen dynamics of $\mathrm{N}_{2}$-fixing field-grown Alnus glutinosa under elevated atmospheric $\mathrm{CO}_{2}$. Global Change Biol 1:55-61

Wang K, Kellomaki S, Laitinen K (1995) Effects of needle age, long-term temperature and $\mathrm{CO}_{2}$ treatments on the photosynthesis of scots pine. Tree Physiol 15:211-218

Williams RS, Lincoln DE, Thomas RB (1994) Loblolly pine grown under elevated $\mathrm{CO}_{2}$ affects early instar pine sawfly performance. Oecologia 98:64-71

Wullschleger SD, Norby RJ (1992) Respiratory cost of leaf growth and maintenance in white oak saplings exposed to atmospheric $\mathrm{CO}_{2}$ enrichment. Can I For Res 22:1717-1721

Wullschleger SD, Norby RJ, Gunderson CA (1992a) Growth and maintenance respiration in leaves of Liriodendron tulipifera $\mathbf{L}$. exposed to long-term carbon dioxide enrichment in the field. New Phytol 21:515-523

Wullschleger SD, Norby RJ, Hendrix DL (1992b) Carbon exchange rates, chlorophyll content, and carbohydrate status of two forest tree species exposed to carbon dioxide enrichment. Tree Physiol 10:21-31

Wullschleger SD, Norby RJ, Hanson PJ (1995) Growth and maintenance respiration in stems of Quercus alba after four years of $\mathrm{CO}_{2}$ enrichment. Physiol Plant 93:47-54

Yakimchuk R, Hoddinott $J$ (1994) The influence of ultraviolet-B light and carbon dioxide enrichment on the growth and physiology of seedlings of three conifer species. Can J For Res 24: $1-8$

Ziska LH, Hogan KP, Smith AP, Drake BG (1991) Growth and photosynthetic response of nine tropical species with longterm exposure to elevated carbon dioxide. Oecologia 86:383389
Appendix 2 The species, environmental stress factors in addition to $\mathrm{CO}_{2}$ (Stress), variables measured, and citation for all studies used in the meta-analysis. The variables measured were: total above+ below-ground biomass $\left(W_{\mathrm{T}}\right)$, below-ground biomass $\left(W_{\mathrm{B}}\right)$, stem biomass $\left(W_{\mathrm{S}}\right)$, total leaf biomass $\left(W_{\mathrm{L}}\right)$, light saturated net $\mathrm{CO}_{2}$ assimilation $(A)$, photosynthetic acclimation or downregulation ( $\left.A_{\mathrm{accl}}\right)$, stomatal conductance $\left(g_{\mathrm{s}}\right)$, leaf dark respiration $\left(R_{\mathrm{d}}\right.$, expressed on a leaf mass basis), leaf nitrogen concentration ( $N_{\mathrm{L}}$ ex pressed on a mass basis), and leaf starch concentration ( $\mathrm{St}_{\mathrm{L}}$ expressed on a mass basis). The entire database, containing nearly 800 observations (at the time of this writing), is available for public use from the Carbon Dioxide Information and Analysis Center (CDIAC, Oak Ridge National Laboratory). Files may be obtained by anonymous FTP at address: cdiac.esd.oml.gov, directory pubi db1018. Access codes and other important information are viewable in the readme file. The database can also be accessed via CDIAC's homepage: http://cdiac.esd.ornl.gov, under Products and Services, Anonymous FTP Service, FTP area, db1018.

\begin{tabular}{|c|c|c|c|c|c|c|c|c|c|c|c|c|}
\hline Species & Stress & $W_{\mathbf{T}}$ & $W_{\mathrm{L}}$ & $W_{\mathrm{S}}$ & $W_{\mathrm{B}}$ & $A$ & $A_{\text {accl }}$ & $g_{s}$ & $R_{\mathrm{d}}$ & $N_{\mathrm{L}}$ & $\mathrm{St}_{\mathrm{L}}$ & Citation \\
\hline Acacia mangium & None & & & & & * & & & & & & Ziska et al. (1991) \\
\hline Acer pensylvanicum & Fert & & * & * & & & & * & & & & Bassow et al. (1994) \\
\hline Acer pensylvanicum & Fert & & & & * & & & & & & & Bassow et al. (1994) \\
\hline Acer pensylvanicum & Fert/light & & & & $*$ & & & & & & & Bazzaz and Miao (1993) \\
\hline Acer pensylvanicum & Fert/light & * & & & & & & & & & & Bazzaz and Miao (1993) \\
\hline Acer pensylvanicum & Fert/light & * & & & & & & & & & & Bazzaz et al. (1993) \\
\hline Acer rubrum & Fert/light & & & & * & & & & & & & Bazzaz and Miao (1993) \\
\hline Acer rubrum & Fert/light & * & & & & & & & & & & Bazzaz and Miao (1993) \\
\hline Acer rubrum & Fert/light & * & & & & & & & & & & Bazzaz et al. (1993) \\
\hline Acer rubrum & None & * & & & & & & & & & & Bunce (1992) \\
\hline Acer rubrum & Light & & & & & * & & * & & * & & Kubiske and Pregitzer (1996) \\
\hline Acer saccharinum & None & * & & & & * & & $*$ & & & & Bunce (1992) \\
\hline Acer saccharum & None & * & * & & & & & & & * & * & Lindroth et al. (1993) \\
\hline Acer saccharum & Temp & & & & & * & & * & & & & Norby et al. (1996) \\
\hline Acer saccharum & None & & & & & & & & & * & & Reid and Strain (1994) \\
\hline Acer saccharum & None & & & & & * & & & & & & Reid and Strain (1994) \\
\hline
\end{tabular}


Appendix 2 (continued)

\begin{tabular}{|c|c|c|c|c|c|c|c|c|c|c|c|c|}
\hline Species & Stress & $W_{\mathrm{T}}$ & $W_{\mathrm{L}}$ & $W_{\mathrm{S}}$ & $W_{\mathbf{B}}$ & $A$ & $A_{\text {accl }}$ & $g_{\mathrm{s}}$ & $R_{\mathrm{d}}$ & $N_{\mathrm{L}}$ & $S t_{L}$ & Citation \\
\hline Alnus glutinosa & None & & & & & * & & * & * & * & & Vogel and Curtis (1995) \\
\hline Alnus rubra & Fert & * & $*$ & * & * & * & & & & * & & Amone and Gordon (1990) \\
\hline Betula alleghaniensis & Fert & & * & * & $*$ & & & * & & & & Bassow et al. (1994) \\
\hline Betula alleghaniensis & Fert/light & * & & & * & & & & & & & Bazzaz and Miao (1993) \\
\hline Betula alleghaniensis & Fert/light & * & & & & & & & & & & Bazzaz et al. (1993) \\
\hline Betula alleghaniensis & None & $*$ & $*$ & $*$ & $*$ & & & & & * & & Rochefort and Bazzaz (1992) \\
\hline Betula lenta & None & * & * & * & * & & & & & * & & Rochefort and Bazzaz (1992) \\
\hline Betula papyrifera & Light & & & & & * & & * & & * & & Kubiske and Pregitzer (1994) \\
\hline Betula papyrifera & None & * & * & * & * & & & & & * & & Rochefort and Bazzaz (1992) \\
\hline Betula papyrifera & None & & & & & & & & & * & * & Roth and Lindroth (1994) \\
\hline Betula pendula & Temp & * & & & & * & * & & $*$ & & & Mortensen (1994) \\
\hline Betula pendula & None & * & & & & $*$ & & $*$ & & * & * & $\begin{array}{l}\text { Pettersson and McDonald } \\
\text { (1992) }\end{array}$ \\
\hline Betula pendula & Fert & & & & & & & & & * & * & Pettersson et al. (1993) \\
\hline Betula populifolia & Fert & & * & * & $*$ & & & $*$ & & & & Bassow et al. (1994) \\
\hline Betula populifolia & Fert/light & * & & & * & & & & & & & Bazzaz and Miao (1993) \\
\hline Betula populifolia & Fert/light & $*$ & & & & & & & & & & Bazzaz et al. (1993) \\
\hline Betula populifolia & None & * & * & * & * & & & & & * & & Rochefort and Bazzaz (1992) \\
\hline Betula pubescens & $\mathrm{O}_{3} /$ temp & * & $*$ & $*$ & * & & & & & & & Mortensen (1995) \\
\hline Brachychiton populneum & None & & & & & * & & & & & & Idso and Kimball (1993) \\
\hline Castanea sativa & None & * & & * & & & & & & & & Couteaux et al. (1992) \\
\hline Castanea sativa & None & & & & & & & & * & & & El Kohen et al. (1991) \\
\hline Castanea sativa & Fert & * & * & * & * & & & & & * & & El Kohen et al. (1992) \\
\hline Castanea sativa & None & $*$ & * & * & * & * & & & & & & El Kohen et al. (1993) \\
\hline Castanea sativa & None & * & * & * & * & * & & & * & & & Mousseau (1993) \\
\hline Castanea sativa & None & * & & * & * & & & & & & & Mousseau and Enoch (1989) \\
\hline Cecropia obtusifolia & None/comp & * & & & & * & & * & & & & Reekie and Bazzaz (1989) \\
\hline Cedrus atlantica & None & & & & & $*$ & * & $*$ & & & $*$ & Kaushal et al. (1989) \\
\hline Citrus aurantium & None & & $*$ & * & $*$ & & & & & & & Ferguson et al. (1986) \\
\hline Citrus aurantium & None & & & & & * & & & & & & Idso et al. (1991) \\
\hline Citrus sinensis & None & $*$ & $*$ & $*$ & * & $*$ & * & & & & & Downton et al. (1987) \\
\hline Eucalyptus microtheca & None & & & & & * & & & & & & Idso and Kimball (1993) \\
\hline $\begin{array}{l}\text { Eucalyptus } \\
\text { polyanthemus }\end{array}$ & None & & & & & $*$ & & & & & & Idso and Kimball (1993) \\
\hline Eucalyptus tetrodonta & None & & & & & * & & & & & & Eamus et al. (1995a) \\
\hline Fagus grandifolia & None & & & & & * & & & & * & & Reid and Strain (1994) \\
\hline Fagus sylvatica & None & & . & & & * & & & & & & El Kohen et al. (1993) \\
\hline Fagus sylvatica & None & & & & & * & * & & & & & Jarvis et al. (1994) \\
\hline Ficus obtusifolia & None & & & & & * & & & & & & Ziska et al. (1991) \\
\hline Fraxinus americana & Fert/light & * & & & * & & & & & & & Bazzaz and Miao (1993) \\
\hline Fraxinus americana. & Fert/light & * & & & & & & & & & & Bazzaz et al. (1993) \\
\hline Garcinia mangostana & None & & $*$ & * & * & $*$ & * & & & & & Downton et al. (1990) \\
\hline Gliricidia sepium & Fert & & & & & & & & & * & & Thomas et al. (1991) \\
\hline Lindera benzoin & None & & & & & & & & & * & & Cipollini et al. (1993) \\
\hline Liquidambar styraciflua & None & & & & & $*$ & $*$ & * & & & & Fetcher et al. (1988) \\
\hline Liriodendron tulipfera & None & & & & & & & & $*$ & $*$ & & Wullschleger et al. (1992a) \\
\hline Liriodendron tulipifera & None & & & & & * & & * & & & & Gunderson et al. (1993) \\
\hline Liriodendron tulipifera & Fert & * & * & * & * & $*$ & & * & & * & & Norby and O'Neill (1991) \\
\hline Liriodendron tulipifera & None & & * & $*$ & & * & & & * & & & Norby et al. (1992) \\
\hline Liriodendron tulipifera & None & & & & & * & & * & * & & * & Wullschleger et al. (1992b) \\
\hline Malus domestica & None & $*$ & & & & * & & * & & & & Bunce (1992) \\
\hline Maranthes corymbosa & None & $*$ & $*$ & $*$ & * & & & & & & & Berryman et al. (1993) \\
\hline Maranthes corymbosa & None & & & & & * & * & * & & & & Eamus et al. (1993) \\
\hline Maranthes corymbosa & None & & & & & & & * & & & & Eamus et al. (1995b) \\
\hline Myriocarpa longipes & None/comp & $*$ & & & & * & & $*$ & & & & Reekie and Bazzaz (1989) \\
\hline Nothofagus fusca & None & $*$ & & & & * & * & $*$ & & & & Hollinger (1987) \\
\hline Picea abies & None & & & & & & * & & & & & Marek et al. (1995) \\
\hline Picea abies & Temp & $*$ & & & & * & * & & * & & & Mortensen (1994) \\
\hline Picea abies & $\mathrm{O}_{3}$ & $*$ & & & & & & & & & & Polle et al. (1993) \\
\hline Picea glauca & UVB & $*$ & $*$ & $*$ & $*$ & & & & & & & $\begin{array}{l}\text { Yakimchuk and Hoddinott } \\
\text { (1994) }\end{array}$ \\
\hline Picea mariana & Fert $/ \mathrm{H}_{2} \mathrm{O}$ & * & & & & $*$ & $*$ & $*$ & & & & Johnsen (1993) \\
\hline Picea mariana & UVB & $*$ & $*$ & * & * & & & & & & & $\begin{array}{l}\text { Yakimchuk and Hoddinott } \\
\text { (1994) }\end{array}$ \\
\hline Pinus banksiana & UVB & $*$ & & & & & & & & & & Stewart and Hoddinott \\
\hline Pinus banksiana & UVB & * & $*$ & $*$ & $*$ & & & & & & & $\begin{array}{l}(1993) \\
\text { Yakimchuk and Hoddinott } \\
\text { (1994) }\end{array}$ \\
\hline
\end{tabular}


Appendix 2 (continued)

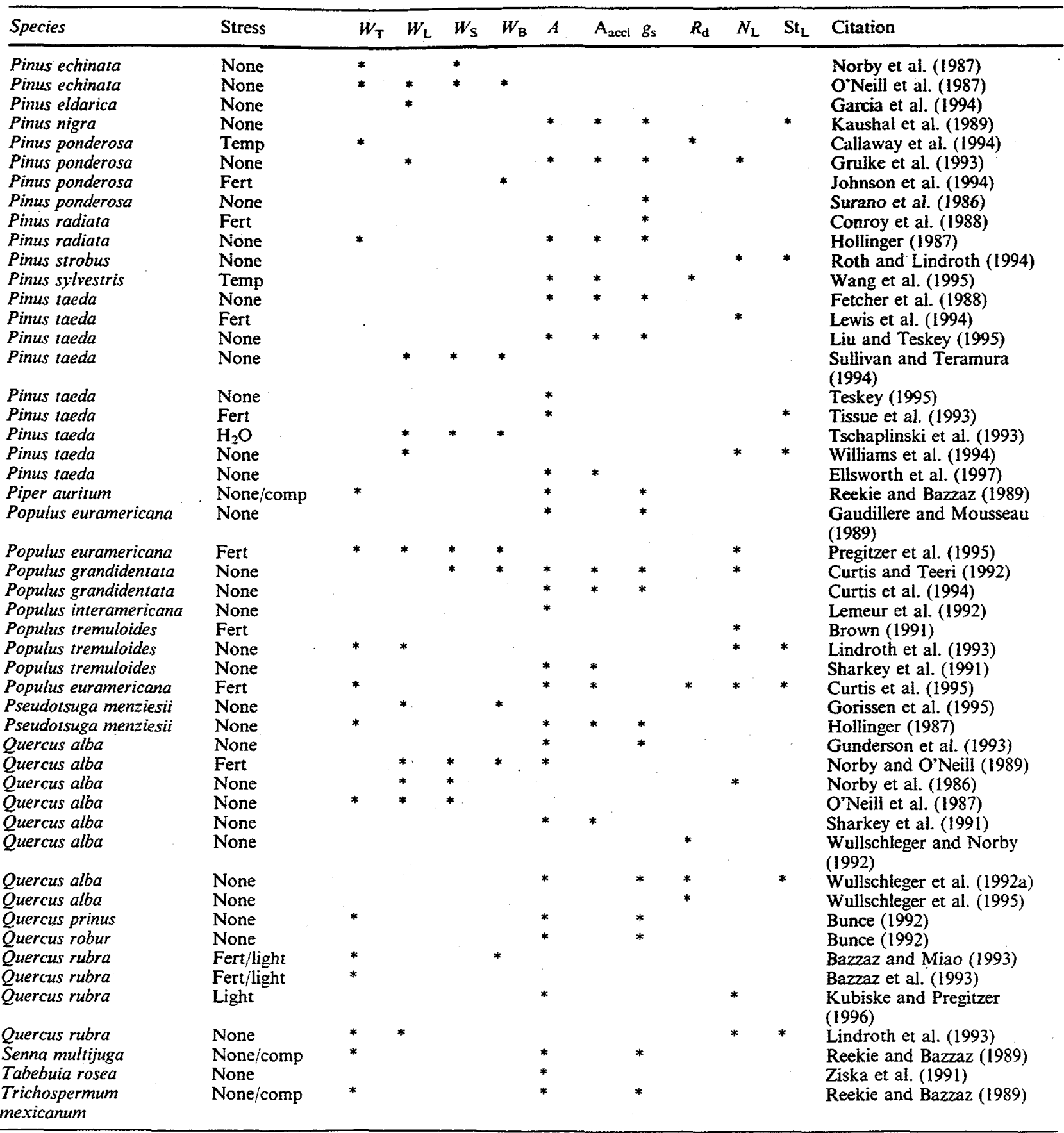




\section{References}

Amthor JS (1994) Plant respiratory responses to the environment and their effects on the carbon balance. In: Wilkerson RE (ed) Plant-environment interactions. Marcel Dekker, New York

Arnqvist $G$, Wooster D (1995) Meta-analysis: synthesizing research findings in ecology and evolution. Trends Ecol Evol 10:236240

Bassow SL, McConnaughay KDM, Bazzaz FA (1994) The response of temperate tree seedlings grown in elevated $\mathrm{CO}_{2}$ to extreme temperature events. Ecol Appl 4:593-603

Bazzaz FA, Miao SL (1993) Successional status, seed size, and responses of tree seedlings to $\mathrm{CO}_{2}$, light, and nutrients. Ecology 74:104-112

Bunce JA (1992) Stomatal conductance, photosynthesis and respiration of temperate deciduous tree seedlings grown outdoors at an elevated concentration of carbon dioxide. Plant Cell Environ 15:541-549

Ceulemans R, Mousseau M (1994) Effects of elevated atmospheric $\mathrm{CO}_{2}$ on woody plants. New Phytol 127:425-446

Cipollini ML, Drake BG, Whigham D (1993) Effects of elevated $\mathrm{CO}_{2}$ on growth and carbon/nutrient balance in the deciduous woody shrub Lindera benzoin (L.) Blume (Lauraceae). Oecologia 96:339-346

Cooper H, Hedges LV (eds) (1994) The handbook of research synthesis. Russell Sage Foundation, New York

Cooper HM, Rosenthal R (1980) Statistical versus traditional procedures for summarizing research findings. Psychol Bull 87:442-449

Cure JD (1985) Carbon dioxide doubling responses: a crop survey. In: Strain BR, Cure JD (eds) Direct effects of increasing carbon dioxide on vegetation. United State Department of Energy, Washington

Curtis PS (1996) A meta-analysis of leaf gas exchange and nitrogen in trees grown under elevated carbon dioxide. Plant Cell Environ 19:127-137

Curtis PS, Vogel CS, Pregitzer KS, Zak DR, Teeri JA (1995) Interacting effects of soil fertility and atmospheric $\mathrm{CO}_{2}$ on leaf area growth and carbon gain physiology in Populus $\times$ euramericana (Dode) Guinier. New Phytol:253-263

Davidson RL (1969) Effect of root: leaf temperature differentials on root: shoot ratios in some pasture grasses and clover. Ann Bot 33:561-569

Downton WJS, Grant WJR, Chacko EK (1990) Effect of elevated carbon dioxide on the photosynthesis and early growth of mangosteen (Garcinia mangostana L.). Sci Hort 44:215-225

Eamus D, Jarvis PG (1989) Direct effects of $\mathrm{CO}_{2}$ increases on trees and forests (natural and commercial) in the UK. Adv Ecol Res 19:1-55

Eamus D, Duff GA, Berryman CA (1995) Photosynthetic responses to temperature, light, flux-density, $\mathrm{CO}_{2}$ concentration and vapour pressure deficit in Eucalyptus tetrodonta grown under $\mathrm{CO}_{2}$ enrichment. Environ Pollut 90:41-49

Ellsworth DS, LaRoche J, Hendrey GR (1997) Photosynthesis and leaf nitrogen in a maturing pine forest under free-air $\mathrm{CO}_{2}$ enrichment (FACE) (Report BNL \#61741). Department of Applied Science, Brookhaven National Laboratory, Upton

Farquhar GD, Sharkey TD (1982) Stomatal conductance and photosynthesis. Annu Rev Plant Physiol 33:317-345

Field C, Mooney HA (1986) The photosynthesis-nitrogen relationship in wild plants. In: Givinish TJ (ed) On the economy of plant form and function. Cambridge University Press, Cambridge, pp 25-55

Grulke NE, Hom JL, Roberts SW (1993) Physiological adjustment of two full-sib families of ponderosa pine to elevated $\mathrm{CO}_{2}$. Tree Physiol 12:391-401

Gunderson CA, Wullschleger SD (1994) Photosynthetic acclimation in trees to rising atmospheric $\mathrm{CO}_{2}$ : a broader perspective. Photosynth Res 39:369-388

Gurevitch J, Hedes IV (1993) Meta-analysis: combining the results of independent experiments. In: Scheiner SM, Gurevitch 3 (eds) Design and analysis of ecological experiments. Chapman and Hall, New York, pp 378-398

Hedges LV, Olkin I (1985) Statistical methods for meta-analysis. Academic Press, New York

Hollinger DY (1987) Gas exchange and dry matter allocation responses to elevation of atmospheric $\mathrm{CO}_{2}$ concentration in seedlings of three tree species. Tree Physiol 3:193-202

Houghton JT, Jenkins GJ, Ephraums JJ (eds) (1990) Climate change: the IPCC scientific assessment. Cambridge University Press, Cambridge

Idso KE, Idso SB (1994) Plant responses to atmospheric $\mathrm{CO}_{2}$ enrichment in the face of environmental constraints: a review of the past 10 years' research. Agric For Meteorol 69:153-203

Johnsen KH (1993) Growth and ecophysiological responses of black spruce seedlings to elevated $\mathrm{CO}_{2}$ under varied water and nutrient additions. Can J For Res 23:1033-1042

Johnson D, Geisinger D, Walker R, Newman J, Vose J, Elliot K, Ball $\mathrm{T}$ (1994) Soil $\mathrm{pCO}_{2}$, soil respiration, and root activity in $\mathrm{CO}_{2}$-fumigated and nitrogen-fertilized pondersosa pine. Plant Soil 165:129-138

Kaushal P, Guehl JM, Aussenac G (1989) Differential growth response to atmospheric carbon dioxide enrichment in seedlings of Cedrus atlantica and Pinus nigra ssp. laricia var. corsicana. Can J For Res 19:1351-1358

Kennedy AD (1995) Simulated climate change: are passive green houses a valid microcosm for testing the biological effects of environmental perturbations? Global Change Biol 1:29-42

Kimball BA (1983) Carbon dioxide and agricultural yield: an assemblage and analysis of 430 prior observations. Agron J 75:779-788

Kubiske ME, Pregitzer KS (1996) Effects of elevated $\mathrm{CO}_{2}$ and light availability on the photosynthetic light response of trees of contrasting shade tolerance. Tree Physiol 16:35I-358

Liu S, Teskey RO (1995) Responses of foliar gas exchange to longterm elevated $\mathrm{CO}_{2}$ concentrations in mature loblolly pine trees. Tree Physiol 15:351-359

Luo $Y$, Field CB, Mooney HA (1994) Predicting responses of photosynthesis and root fraction to elevated $\left[\mathrm{CO}_{2}\right]_{\mathrm{a}}$ : interactions among carbon, nitrogen, and growth. Plant Cell Environ $17: 1195-1204$

Mann CC (1990) Meta-analysis in the breech. Science 249:476-480

Mann CC (1994) Can meta-analysis make policy? Science 266: 960-962

McConnaughay KDM, Berntson GM, Bazzaz F (1993) Limitations to $\mathrm{CO}_{2}$-induced growth enhancement in pot studies. Oecologia 94:550-557

McGuire D, Melillo JM, Joyce LA (1995) The role of nitrogen in the response of forest net primary production to elevated atmospheric carbon dioxide. Annu Rev Ecol Syst 26:473-503

Melillo JM, McGuire AD, Kicklighter DW, Moore III B, Vorosmarty CJ, Scholoss AL (1993) Global climate change and terrestrial net primary production. Nature 363:234-240

Miller N, Pollock VE (1994) Meta-analytic synthesis for theory development. In: Cooper H, Hedges LV (eds) The handbook of research synthesis. Russell Sage Foundation, New York, pp $457-483$

Meyer WB, Turner BL (1992) Human population growth and global land-use/cover change. Annu Rev Ecol Syst 23:39-61

Norby RJ (1994) Issues and perspectives for investigating root responses to elevated atmospheric carbon dioxide. Plant Soil 165:9-20

Norby RJ, O'Neill EG (1991) Leaf area compensation and nutrient interactions in $\mathrm{CO}_{2}$-enriched seedlings of yellow-poplar (Liriodendron tulipifera L.). New Phytol 117:515-528

O'Neill EG, Norby RJ (1996) Litter quality and decomposition rates of foliar litter produced under $\mathrm{CO}_{2}$ enrichment. In: Koch GW. Mooney HA (eds) Carbon dioxide and terrestrial ecosystems. Academic Press, New York, pp 87-103

Pettersson R, McDonald AJS (1992) Effects of elevated carbon dioxide concentration on photosynthesis and growth of small birch plants (Betula pendula Roth.) at optimal nutrition. Plant Cell Environ 15:911-919 
Reynolds JF, Thornley JHM (1982) A shoot: root partitioning model. Ann Bot 49:585-597

Rosenberg MS, Adams DC, Gurevitch J (1996) MetaWin. Statistical software for conducting meta-analysis: fixed effect models, mixed effect models, and resampling tests, version 1.0 . Sinauer, Sunderland

Ryan MG (1991) Effects of climate on plant respiration. Ecol Appl $1: 157-167$

Sage RF (1994) Acclimation of photosynthesis to increasing atmospheric $\mathrm{CO}_{2}$ : the gas exchange perspective. Photosynth Res 39:351-368

Schulze ED, Mooney HA (eds) (1994) Design and execution of experiments on $\mathrm{CO}_{2}$ enrichment. Commission of the European Communities, Luxembourg

Sharkey TD, Loreto F, Deiwiche CF (1991) High carbon dioxide and sun/shade effects on isoprene emission from oak and aspen tree leaves. Plant Cell Environ 14:333-338

Stitt $\mathrm{M}$ (1991) Rising $\mathrm{CO}_{2}$ levels and their potential significance for carbon flow in photosynthetic cells. Plant Cell Environ 14: 741-762

Strain BR, Cure JD (1986) Direct effects of atmospheric $\mathrm{CO}_{2}$ enrichment on plants and ecosystems: a bibliography with abstracts. Oak Ridge National Laboratory, Oak Ridge
Strain BR, Cure JD (1994) Direct effects of atmospheric $\mathrm{CO}_{2}$ enrichment on plants and ecosystems: an updated bibliographic data base. Oak Ridge National Laboratory, Oak Ridge

Thomas RB, Strain BR (1991) Root restriction as a factor in photosynthetic acclimation of cotton seedlings grown in elevated carbon dioxide. Plant Physiol 96:629-634

Walker JCG, Kasting JF (1992) Effects of fuel and forest conservation on future levels of atmospheric carbon dioxide. Palaeogeogr Palaeoclimatol Palaeoecol 97:151-189

Wullschleger SD, Ziska LH, Bunce JA (1994) Respiratory responses of higher plants to atmospheric $\mathrm{CO}_{2}$ enrichment. Physiol Plant 90:221-229

Wullschleger SD, Post WM, King AW (1995) On the potential for a $\mathrm{CO}_{2}$ fertilization effect in forests: Estimates of the biotic growth factor based on 58 controlled-exposure studies. In: Woodwell AW, Mackensie FT (eds) Biospheric feedbacks in the global climate system: will warming feed the warming? Oxford University Press, pp 85-107

Zak DR, Pregitzer KS, Curtis PS, Teeri JA. Fogel R, Randlett DL (1993) Elevated atmospheric $\mathrm{CO}_{2}$ and feedback between carbon and nitrogen cycles. Plant Soil 151:105-117 


\section{Internal Distribution}

$\begin{aligned} \text { 1. } & \text { L. J. Allison } \\ \text { 2. } & \text { T. A. Boden } \\ \text { 3. } & \text { M. D. Burtis } \\ \text { 4. } & \text { M.-D. Cheng } \\ \text { 5. } & \text { R. M. Cushman } \\ 6 . & \text { K. N. Gibson } \\ \text { 7. } & \text { S. G. Hildebrand } \\ 8 . & \text { L. A. Hook } \\ 9-58 . & \text { S. B. Jones } \\ 59 . & \text { D. P. Kaiser } \\ 60 . & \text { P. Kanciruk }\end{aligned}$

\author{
61. A. Kozyr \\ 62. J. M. Loar \\ 63. G. M. Logsdon \\ 64. G. Marland \\ 65. T. E. Myrick \\ 66. D. E. Reichle \\ 67. D. E. Shepherd \\ 68. L. D. Voorhees \\ 69-72. ESD Library \\ 73. Laboratory Records Dept.
}

\section{External Distribution}

74. D. Ahmann, Division of Environmental Sciences and Engineering, Colorado School of Mines, Golden, CO 80401

75. A. Brenkhert, $282539^{\text {th }}$ St. NW, Washington, DC 20007

76. R. Ceulemans, Department of Biology, University of Antwerpen (UIA) Universiteitsplein 1, B-2610 Wilrijk, Belgium

77. P. A. Crowley, Environmental Sciences Division, Office of Biological and Environmental Research, SC-74, Department of Energy, 19901 Germantown Rd., Germantown, MD 20874

78. E. G. Cumesty, Assistant Manager for Laboratories and Site Manager, Department of Energy, Oak Ridge National Laboratory, P.O. Box 2008, Oak Ridge, TN 37831-6269

79-88. P. S. Curtis, Department of Evolution, Ecology, and Organismal Biology, The Ohio State University, Columbus, OH 43210-1293

89. R. C. Dahlman, Environmental Sciences Division, Office of Biological and Environmental Research, SC-74, Department of Energy, 19901 Germantown Rd., Germantown, MD 20874

90. J. Elwood, Acting Director, Environmental Sciences Division, SC-74, Department of Energy, 19901 Germantown Road, Germantown, MD 20874

91. Energy Library (HR-832.1/GTN), Department of Energy, Office of Administration and Management, G-034, Washington, D.C. 20585

92. Energy Library (HR-832.2/WAS), Department of Energy, Office of Administration and Management, GA-138 Forrestal Building, Washington, D.C. 20585

93. W. Ferrell, Environmental Sciences Division, Office of Biological and Environmental Research, SC-74, Department of Energy, 19901 Germantown Rd., Germantown, MD 20874

94. J. P. Giesy, Michigan State University, College of Natural Science, Department of Zoology, 203 Natural Science Building, East Lansing, MI 48824-1115

95. M. A. Gonzalez-Meler, DCMB Group/ Botany Department, Box 91000, Duke University, Durham, NC-27708-1000

96. D. L. Hemming, Laboratory of Tree Ring Research, Building \# 58, West Stadium, University of Arizona, Tucson, AZ 85719

97. G. R. Hendrey, Head, Division of Environmental Biology and Instrumentation, Bldg. 490 D, Brookhaven National Laboratory, P. O. Box 5000, Upton, New York 11973-5000

98. A. M. Hittelman, Director, World Data Center-A for Solid Earth Geophysics, NOAA, National Geophysical Data Center (NGDC), 325 Broadway, Boulder, CO 80303 
99. J. C. Houghton, Environmental Sciences Division, Office of Biological and Environmental Research, SC-74, Department of Energy, 19901 Germantown Rd., Germantown, MD 20874

100. B. A. Kimball, Research Leader, Environmental and Plant Dynamics Research Group, U.S. Water Conservation Laboratory, USDA, Agricultural Research Service, 4331 East Broadway Road, Phoenix, AZ 85040

101. R. L. Lindroth, Department of Entomology, 1630 Linden Drive, University of Wisconsin, Madison, WI 53706

102. A. A. Lucier, National Council of the Paper Industry for Air and Stream Improvement, Inc., P.O. Box 13318, Research Triangle Park, NC 27709-3318

103. M. C. MacCracken, National Assessment Coordination Office, Suite 750, 400 Virginia Avenue, Washington, DC 20024

104. A. McLeod, Assistant Director, Centre for the Study of Environmental Change and Sustainability (CECS), The University of Edinburgh, John Muir Building, The Kings Buildings, Mayfield Road, Edinburgh EH9 3JL, Scotland

105. A. C. Palmisano, Department of Energy, Office of Biological and Environmental Research, Environmental Sciences Division, SC-74, 19901 Germantown Road, Germantown, MD 20874

106. B. Parra, Environmental Sciences Division, Office of Biological and Environmental Research, SC-74, Department of Energy, 19901 Germantown Rd., Germantown, MD 20874

107. A. Patrinos, Associate Director, Office of Biological and Environmental Research, SC-70, Department of Energy, 19901 Germantown Rd., Germantown, MD 20874

108. J. Penuelas, CREAF (Center for Ecological Research and Forestry Applications), Facultat de Ciencies, Universitat Autonoma de Barcelona, 08193 Bellaterra, Barcelona, Spain

109. L. F. Pitelka, Appalachian Laboratory, 301 Braddock Road, Frostburg, MD 21532

110. M. R. Riches, Office of Biological and Environmental Research, SC-74, Department of Energy, 19901 Germantown Rd., Germantown, MD 20874

111. S. Roberts, Data Design Group, PO Box 3318, La Jolla CA 92038-3318

112. L. Robinson, Director, Environmental Sciences Institute, Florida A\&M University, Science Research Facility, 1520 S. Bronough Street, Tallahassee, FL 32307-6600

113. H. Rogers, Global Change Research, National Soil Dynamics Laboratory, USDA-ARS, 411 South Donahue Drive, Auburn, AL 36832

114. J. M. Tiedje, University Distinguished Professor and Director, 540 Plant and Soil Sciences Building, Michigan State University, East Lansing, MI 48824

115. S. J. Tonsor, Department of Biological Sciences, The University of Pittsburgh, 162 Crawford Hall, Pittsburgh PA 15260

116. H. F. Vugts, Dept. of Meteorology, Vrije Universiteit, Inst. voor Aardwetenschappen, De Boelelaan 1085, $1081 \mathrm{HV}$ Amsterdam, The Netherlands

117-118. Office of Science and Technical Information, P. O. Box 62, Oak Ridge, TN 37831 